

\title{
BUKU AJAR AKUNTANSI PERBANKAN SYARIAH (TEORI DAN PRAKTEK)
}

\author{
Oleh \\ Dr. Renny Oktafia, S.E., M.E.I. \\ Nihlatul Qudus Sukma Nirwana, S.E., M.M
}

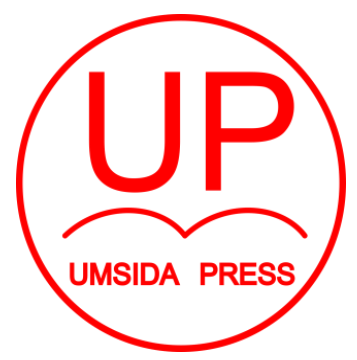

UNIVERSITAS MUHAMMADIYAH SIDOARJO

2020 
BUKU AJAR

AKUNTANSI PERBANKAN SYARIAH (TEORI DAN PRAKTEK)

\section{Penulis:}

Dr. Renny Oktafia, S.E., M.E.I

Nihlatul Qudus Sukma Nirwana, S.E., M.M

ISBN :

978-623-6833-30-8

\section{Editor:}

Dr. Sigit Hermawan, SE. M.Si

\section{Design Sampul dan Tata Letak:}

Mochammad Nashrullah, S.Pd.

Amy Yoga Prajati, S.Kom.

Penerbit:

UMSIDA Press

Anggota IKAPI No. 218/Anggota Luar Biasa/JTI/2019

Anggota APPTI No. 0020181092017

Redaksi

Universitas Muhammadiyah Sidoarjo

Jl. Mojopahit No 666B

Sidoarjo, Jawa Timur

Cetakan Pertama, November 2020

CHak Cipta dilindungi undang undang

Dilarang memperbanyak karya tulis ini dengan sengaja, tanpa ijin tertulis dari penerbit. 


\section{KATA PENGANTAR}

Puji syukur kami panjatkan kehadirat Allah SWT, atas rahmat dan karunia-Nya Buku Ajar Akuntansi Perbankan Syariah (Teori dan Praktek) dapat diselesaikan dengan baik dan tanpa halangan yang berarti. Shalawat dan salam selalu kami sampaikan kepada junjungan Nabi Muhammad SAW.

Tim penulis mengucapkan terimakasih kepada:

1. Dr. Istikomah, M.Ag., Dekan Fakultas Agama Islam yang memberikan arahan dan motivasi kepada penulis dalam menyelesaikan buku ajar ini.

2. Fitri Nur Latifah, S.E., M.E.Sy., Kaprodi Perbankan Syariah yang telah memberikan dukungan untuk menyusun buku ajar ini.

3. Rekan-rekan dosen Prodi Perbankan Syariah dan Prodi Akuntansi yang telah berbagi ilmu.

Saran dan kritik sangat penulis harapkan untuk mewujudkan buku ajar Akuntansi Perbankan Syariah (Teori dan Praktek) yang lebih baik dan tentunya sesuai dengan amanat peraturan yang berlaku. Terimakasih.

Tim Penulis 


\section{DAFTAR ISI}

KATA PENGANTAR ERROR! BOOKMARK NOT DEFINED.

DAFTAR ISI

BAB I KONSEP DAN PRINSIP DASAR BANK SYARIAH.................... 1

A. KONSEP DASAR BANK SYARIAH ....................................... 2

B. PRINSIP-PRINSIP Syariah PEngElolaAn Bank Syariah ....... 5

C. Peranan dan Fungsi Bank Syariah ............................. 16

BAB II SISTEM PENGELOLAAN DAN OPERASIONAL BANK

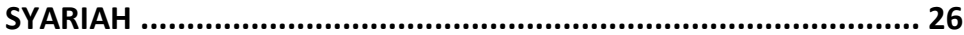

A. AZAS OPERASIONAL BANK SYARIAH .................................. 27

B. Produk Penghimpunan Dana................................... 31

C. Produk PenYaluRan Dana ......................................... 34

D. AKAD PELENGKAP ..................................................... 42

BAB III TEORI DAN PRAKTEK AKUNTANSI TRANSAKSI

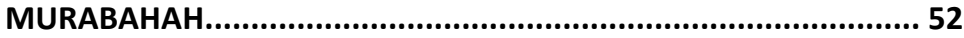

A. DEFINISI MURABAHAH ................................................. 54

B. RukUn PEMBIAYAan MuRABAhah............................... 56

C. SKEMA PEMBIAYAAN MURABAHAH ............................... 57

D. Cakupan AKuntansi PembiayaAn MurabahaH.............. 59

E. AKun TRANSAKSI PEMBIAYAan MURABAHAH .................... 61

F. Studi Kasus TRANSAKSI PEMbiayaAn MURABahaH .......... 74

BAB IV TEORI DAN PRAKTEK AKUNTANSI TRANSAKSI SALAM .... 81

A. DEFINISI SALAM ...................................................... 82

B. RUKUn PEMBIAYAAN SALAM....................................... 82 
C. SKEMA PEMBIAYAAN SALAM ........................................ 84

D. CaKupan AKuntansi PembiayaAn Salam...................... 87

E. AKun TRansaksi PembiayaAn Salam ........................... 89

F. Studi Kasus TRansaksi PEMbiayaAn Salam ................. 115

\section{BAB V TEORI DAN PRAKTEK AKUNTANSI TRANSAKSI ISTISHNA 118}

A. DEFINISI ISTISHNA.................................................... 119

B. RUKUN PEMBIAYAAN ISTISHNA ................................. 121

C. SKEMA PEMBIAYAAN ISTISHNA ................................... 126

D. CAKUPAN AKUnTANSI PEMBIAYAan ISTISHNA .................. 127

E. AKUn TRANSAKSI PEMBIAYAAN ISTISHNA ...................... 138

F. StUdi Kasus TRANSAKSI PEMBIAYAan ISTISHNA .............. 146

\section{BAB VI TEORI DAN PRAKTEK AKUNTANSI TRANSAKSI}

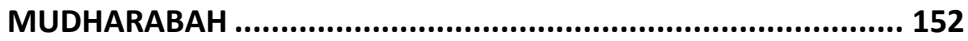
A. DEFINISI MUdHARABAH .......................................... 152
B. RuKun PEMBIAYAan Mudharabah ............................. 154
C. SKema PembiayaAn Mudharabah ............................ 155
D. Cakupan AKuntansi PembiayaAn Mudharabah........... 156
E. AKun TRANSAKSI PEMbiayaAn Mudharabah................. 156
F. Studi Kasus Transaksi PembiayaAn MUdharabah ....... 168

\section{BAB VII TEORI DAN PRAKTEK AKUNTANSI TRANSAKSI}

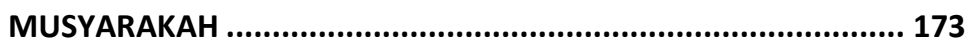
A. Pengertian Musyarakah 174
B. RuKUn PEMBIAYAAN MusYaRAKAH............................ 176
C. SKEMA PEMBIAYAAN MUSYARAKAH ............................ 179
D. CaKupan AKUntansI PEMBiAyaAn MUSYARAKaH........... 181
E. AKun TRansaksi PembiayaAn Musyarakah................. 183
F. Studi Kasus TRANSAKsI PEMbiayaAn Musyarakah ....... 205 
BAB VIII TEORI DAN PRAKTEK AKUNTANSI TRANSAKSI IJARAH 210

A. DEFINISI IJARAH....................................................... 210

B. RUKUN PEMBIAYAAN IJARAH ..................................... 212

C. SKEMA PEMBIAYAAN IJARAH ...................................... 214

D. CAKUPAN AKUNTANSI PEMBIAYAAN IJARAH..................... 215

E. AKUn TRANSAKSI PEMBIAYAAN IJARAH ......................... 219

F. StUdI KasUS TRANSAKSI PEMBIAYAAN IJARAH ................. 225

BAB IX TEORI DAN PRAKTEK AKUNTANSI TRANSAKSI WADIAH 230

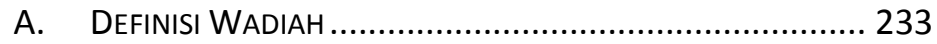

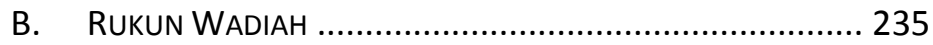

C. SKEMA WADIAH....................................................... 239

D. CAKUPAN AKUNTANSI WADIAH ................................ 241

E. STUDI KASUS TRANSAKSI WADIAH ................................... 243

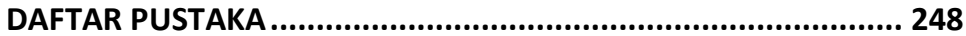

BIODATA PENULIS..................... ERROR! BOOKMARK NOT DEFINED. 


\section{BATANG TUBUH DAN}

\section{SUB-CAPAIAN PEMBELAJARAN MATA KULIAH}

\begin{tabular}{|c|c|}
\hline BAB & Sub-Capaian Pembelajaran Mata Kuliah \\
\hline $\begin{array}{l}\text { BAB I } \\
\text { KONSEP DAN } \\
\text { PRINSIP DASAR } \\
\text { BANK SYARIAH }\end{array}$ & $\begin{array}{l}\text { 1. Mahasiswa mampu memahami konsep konsep dasar } \\
\text { Bank Syariah. } \\
\text { 2. Mahasiswa mampu memahami Prinsip-prinsip } \\
\text { Syariah Pengelolaan Bank Syariah. } \\
\text { 3. Mahasiswa mampu memahami dan menganalisis } \\
\text { peran dan fungsi bank syariah. }\end{array}$ \\
\hline $\begin{array}{l}\text { BAB II } \\
\text { SISTEM } \\
\text { PENGELOLAAN } \\
\text { DAN } \\
\text { OPERASIONAL } \\
\text { BANK SYARIAH }\end{array}$ & $\begin{array}{l}\text { 1. Mahasiswa mampu memahami Azas Operasional } \\
\text { Bank Syariah. } \\
\text { 2. Mahasiswa mampu memahami produk } \\
\text { penghimpunan dana dan menganalisis praktek } \\
\text { penghimpunan dana di Bank Syariah. } \\
\text { 3. Mahasiswa mampu memahami produk penyaluran } \\
\text { dana dan menganalisis praktek penyaluran dana di } \\
\text { Bank Syariah. } \\
\text { 4. Mahasiswa mampu memahami akad pelengkap dan } \\
\text { menganalisis praktek implementasi akad pelengkap. }\end{array}$ \\
\hline $\begin{array}{l}\text { BAB III } \\
\text { TEORI DAN } \\
\text { PRAKTEK } \\
\text { AKUNTANSI } \\
\text { TRANSAKSI } \\
\text { MURABAHAH }\end{array}$ & $\begin{array}{l}\text { 1. Mahasiswa mampu memahami akad murabahah } \\
\text { 2. Mahasiswa mampu memahami rukun murabahah } \\
\text { 3. Mahasiswa mampu memahami skema murabahah } \\
\text { 4. Mahasiswa mampu mengidentifikasi cakupan } \\
\text { akuntansi murabahah. } \\
\text { 5. Mahasiswa mampu mengidentifikasi akun transaksi } \\
\text { murabahah } \\
\text { 6. Mahasiswa mampu mengaplikasikan melalui studi } \\
\text { kasus transaksi murabahah. }\end{array}$ \\
\hline $\begin{array}{l}\text { BAB IV } \\
\text { TEORI DAN } \\
\text { PRAKTEK } \\
\text { AKUNTANSI } \\
\text { TRANSAKSI } \\
\text { SALAM } \\
\end{array}$ & $\begin{array}{l}\text { 1. Mahasiswa mampu memahami akad salam } \\
\text { 2. Mahasiswa mampu memahami rukun salam } \\
\text { 3. Mahasiswa mampu memahami skema salam } \\
\text { 4. Mahasiswa mampu mengidentifikasi cakupan } \\
\text { akuntansi salam. }\end{array}$ \\
\hline
\end{tabular}




\begin{tabular}{|c|c|}
\hline & $\begin{array}{l}\text { 5. Mahasiswa mampu mengidentifikasi akun transaksi } \\
\text { salam. } \\
\text { 6. Mahasiswa mampu mengaplikasikan melalui studi } \\
\text { kasus transaksi salam. }\end{array}$ \\
\hline $\begin{array}{l}\text { BAB V } \\
\text { TEORI DAN } \\
\text { PRAKTEK } \\
\text { AKUNTANSI } \\
\text { TRANSAKSI } \\
\text { ISTISHNA }\end{array}$ & $\begin{array}{l}\text { 1. Mahasiswa mampu memahami akad istishna } \\
\text { 2. Mahasiswa mampu memahami rukun istishna } \\
\text { 3. Mahasiswa mampu memahami skema istishna } \\
\text { 4. Mahasiswa mampu mengidentifikasi cakupan } \\
\text { akuntansi istishna. } \\
\text { 5. Mahasiswa mampu mengidentifikasi akun transaksi } \\
\text { istishna. } \\
\text { 6. Mahasiswa mampu mengaplikasikan melalui studi } \\
\text { kasus transaksi istishna. }\end{array}$ \\
\hline $\begin{array}{l}\text { BAB VI } \\
\text { TEORI DAN } \\
\text { PRAKTEK } \\
\text { AKUNTANSI } \\
\text { TRANSAKSI } \\
\text { MUDHARABAH }\end{array}$ & $\begin{array}{l}\text { 1. Mahasiswa mampu memahami akad mudharabah } \\
\text { 2. Mahasiswa mampu memahami rukun mudharabah } \\
\text { 3. Mahasiswa mampu memahami skema mudharabah } \\
\text { 4. Mahasiswa mampu mengidentifikasi cakupan } \\
\text { akuntansi mudharabah } \\
\text { 5. Mahasiswa mampu mengidentifikasi akun transaksi } \\
\text { mudharabah } \\
\text { 6. Mahasiswa mampu mengaplikasikan melalui studi } \\
\text { kasus transaksi mudharabah }\end{array}$ \\
\hline $\begin{array}{l}\text { BAB VII } \\
\text { TEORI DAN } \\
\text { PRAKTEK } \\
\text { AKUNTANSI } \\
\text { TRANSAKSI } \\
\text { MUSYARAKAH }\end{array}$ & $\begin{array}{l}\text { 1. Mahasiswa mampu memahami akad musyarakah } \\
\text { 2. Mahasiswa mampu memahami rukun musyarakah } \\
\text { 3. Mahasiswa mampu memahami skema musyarakah } \\
\text { 4. Mahasiswa mampu mengidentifikasi cakupan } \\
\text { akuntansi musyarakah } \\
\text { 5. Mahasiswa mampu mengidentifikasi akun transaksi } \\
\text { musyarakah } \\
\text { 6. Mahasiswa mampu mengaplikasikan melalui studi } \\
\text { kasus transaksi musyarakah }\end{array}$ \\
\hline BAB VIII & $\begin{array}{l}\text { 1. Mahasiswa mampu memahami akad ijarah } \\
\text { 2. Mahasiswa mampu memahami rukun ijarah }\end{array}$ \\
\hline
\end{tabular}




\begin{tabular}{|c|c|}
\hline $\begin{array}{l}\text { TEORI DAN } \\
\text { PRAKTEK } \\
\text { AKUNTANSI } \\
\text { TRANSAKSI } \\
\text { IJARAH }\end{array}$ & $\begin{array}{l}\text { 3. Mahasiswa mampu memahami skema ijarah } \\
\text { 4. Mahasiswa mampu mengidentifikasi cakupan } \\
\text { akuntansi ijarah } \\
\text { 5. Mahasiswa mampu mengidentifikasi akun transaksi } \\
\text { ijarah } \\
\text { 6. Mahasiswa mampu mengaplikasikan melalui studi } \\
\text { kasus transaksi ijarah }\end{array}$ \\
\hline $\begin{array}{l}\text { BAB IX } \\
\text { TEORI DAN } \\
\text { PRAKTEK } \\
\text { AKUNTANSI } \\
\text { TRANSAKSI } \\
\text { WADIAH }\end{array}$ & $\begin{array}{l}\text { 1. Mahasiswa mampu memahami akad wadiah } \\
\text { 2. Mahasiswa mampu memahami rukun wadiah } \\
\text { 3. Mahasiswa mampu memahami skema wadiah } \\
\text { 4. Mahasiswa mampu mengidentifikasi cakupan } \\
\text { akuntansi wadiah } \\
\text { 5. Mahasiswa mampu mengidentifikasi akun transaksi } \\
\text { wadiah } \\
\text { 6. Mahasiswa mampu mengaplikasikan melalui studi } \\
\text { kasus transaksi wadiah }\end{array}$ \\
\hline
\end{tabular}




\section{BAB I \\ KONSEP DAN PRINSIP DASAR BANK SYARIAH}

\section{Kompetensi Dasar}

Setelah mempelajari bab ini, diharapkan membentuk mahasiswa yang kompeten dalam hal berikut :

1. Memahami dan mendalami konsep dasar bank syariah

2. Menjelaskan sejarah praktik keuangan syariah sejak masa rasulullah SAW hingga sekarang.

3. Menjelaskan peran Bank Indonesia, IAI dan MUI dalam pembinaan dan pengawasan terhadap perbankan syriah

4. Menjelaskan peran mitra bank syariah di dalam dan luar negeri pengembangan perbankan syariah

5. Mampu membedakan transaksi yang dibolehkan dan yang dilarang menurut syariah

\section{Indikator}

Beberapa indikator yang ada dalam bab ini, sebagai berikut :

1. Pemahaman terhadap prakatik ekonomi syariah sejak masa rasulullah hingga sekarang.

2. Pemahaman terhadap kewajiban bank syariah terhadap BI dan MUI

3. Pemahaman terhadap peran mitra bank syariah di dalam dan luar negeri pengembangan perbankan syariah 


\section{Materi Pokok}

Materi utama pada bab ini adalah perkembangan lembaga keuangan syariah, konsep dan prinsip dasar bank syariah.

\section{A. Konsep Dasar Bank Syariah}

Bank Syariah, secara etimologis terdiri dari dua suku kata yakni bank dan syariah. Kata bank berasal dari italia yakni banco yang berarti bangku. Bangku dalam pengertian ini digunakan oleh bankir untuk kegiatan melayani setiap kegiatan operasionalnya terhadap para nasabah. Istilah bangku sendiri telah populer dengan nama bank. Bank secara definitif adalah badan usaha yang bertujuan menghimpun dana dari masyarakat. Dana tersebut dalam bentuk simpanan dan penyaluran ke masyarakat dalam bentuk sistem kredit atau dengan bentuk yang lainnya dan dalam rangka untuk meningkatkan derajat atau taraf hidup orang banyak.

Untuk istilah syariah sendiri berasal dari bahasa arab yang berarti tata hukum atau pandangan hidup, yakni suatu pernyataan, ketetapan allah yang berwujud perintah dan larangannya. Secara sudah pasti diformulasikan diantaranya oleh Al-Husaini di dalam kitabnya Jamharatul aulia bahwasannya disebutkan syariah yaitu merupakan suatu perintah dan larangan agar setiap insan mentaati kehambaan pada allah (Al-Ubudiyah). Secara teoretis perbankan syariah adalah Sebuah lembaga investasi dan perbankan yang beroperasional sesuai dengan 
prinsip-prinsip yang sesuai syariah. Semua sumber dana yang diperoleh harus sesuai syariah, distribusi investasi yang dilakukan tujuannya untuk mengembangkan ekonomi, sosial dan kesejahteraan masyarakat dan juga jasa-jasa perbankan yng dilakukan sesuai dengan nilai-nilai syariah. ${ }^{1}$

Di bagian lain Firdaus et al mengutarakan beberapa definisi dari bank syariah dari para pakar. Diantaranya yang disampaikan oleh Warkum Sumitro mengatakan bahwasannya bank islam yakni bank yang operasional atau tata caranya didasarkan pada tata cara yang bemuamalah islami, yaitu mengacu pada setiap ketentuan-ketentuan yang ada di Al-Quran dan hadits. Dalam setiap operasionalisasinya, usaha bank yang dilakukan pada zaman rasulullah, bentuk yang sudah ada sebelumnya tetapi tidak dilarang oleh rasulullah atau bentuk usaha yang baru merupakan hasil ijtihad dari para ulama dan cendekiawan muslim yang tentunya tidak akan menyimpang dari semua ketentuan Al Quran dan hadits. Selaras dari pengertian yang diatas, Amin Azis juga memiliki pendapat bahwasannya bank islam adalah Suatu lembaga perbankan yang menggunakan sistem dan operasi berdasarkan syariah islam. Dalam hal ini berarti, operasional dari bank syariah harus dan wajib sesuai dengan tuntunan dari Al Quran dan hadits, yaitu menggunakan sistem yang dinamakan bagi hasil

${ }^{1}$ Marthan, No, 2001. 
dan imbalan yang lain tentunya sesuai dengan syariat islam.

\section{Sedangkan Karnaen A. Perwaatmadja,} mengungkapakan bank syariah adalah bank yang beroperasi sesuai prinsip-prinsip syariah, yaitu bank yang operasional dan tata caranya mengikuti ketentuan dari syariat islam. Salah satu bagian yang harus dijauhi dalam bermuamalah islam yakni praktik yang didalamnya mengandung unsur riba.

Dari sebagian pengertian yang diatas dapat disimpulkan bahwasannya yang dimaksud dari bank islam adalah Sebuah lembaga keuangan yang fungsinya untuk menhimpun dana dan menyalurkannya kepada masyarakat. Dan tidak lupa sistem, tata cara dan mekanisme kegiatan usahanya didasarkan pada syariat islam, yaitu Al-Qur'an dan Hadits. Perbankan syariah bertujuan tidak hanya untuk mencari keuntungan dalam menjalankan sistem operasinalnya saja, tetapi didalamnya terdapat suatu nilai-nilai sosial masyarakat dan spiritualisme yang ingin dicapai. Salah satu perbedaan yang mendasar perbankan syariah dan kovesional yaitu diharamkannya sistem bunga. $^{2}$ Ulama fiqih bersepakat bahwasannya bunga termasuk kedalam jenis barang riba yang telah diharamkan. Dan

${ }^{2}$ Ismail Nawawi, Perbankan Syariah (Surabaya: VIVPRESS, 2011). 
diantaranya pun fatwa yang telah menyatakan bunga adalah riba yang diharamkan.

\section{B. Prinsip-prinsip Syariah Pengelolaan Bank Syariah}

Di dalam manajemen operasional di bank syariah yang berkaitan dengan barang dan jasa, secara garis besarnya hubungan ekonomi yang berdasarkan dengan syariah islam ditentukan oleh hubungan transaksi atau yang bisa disebut dengan aqad terkait dengan berbagai hal yang terdiri dari lima konsep dasar transaksi. Dari sumber kelima konsep dasar tersebut dapat ditemukan pula produk-produk lembaga keuangan bank syariah dan juga lembaga keuangan non bank syariah untuk dioperasionalkan. 5 konsep tersebut yaitu Sistem simpanan, bagi hasil, margin keuntungan, sewa, dan jasa. Konsep-konsep tersebut dapat dijelaskan di uraian bawah ini. ${ }^{3}$

1. Prinsip Simpanan Murni (Al-Wadiah)

Al-Wadiah atau prinsip simpanan muruni ini merupakan salah satu fasilitas yang diberikan oleh bank syariah untuk para nsabah agar memperleh kesempatan ke pihak yang memiliki kelebihan dana untuk menyimpan uangnya dalam bentuk Al-Wadiah .

Umumnya fasilitas Al-Wadiah ini diberikan untuk tujuan investasi agar mendapatkan keuntungan yang sama seperti pada giro atau

${ }^{3}$ Ibid. 
tabungan. Pada perbankan konvensional AlWadih umumnya identik dengan giro.

2. Bagi Hasil Dalam Usaha Bersama (Syirkah)

Pengertian dari sistem ini sendiri yakni suatu sistem yang didalamnya meliputi tata cara pengelolaan pembagian hasil usaha antara penyedia dana dengan si pengelola dana. Pembagian dari hasil usaha ini bisa terjadi antar bank itu sendiri dengan penyimpan dana, ataupun bank dengan nasabah si penerima dana . Bentuk produk yang sesuai dengan prinsip bagi hasil ini adalah mudharabah dan musyarakah. Untuk mudharabah sendiri dapat digunakan sebagai dasar untuk setiap produk pendanaan seperti, tabungan dan deposito. Sementara itu pada musyarakah lebih condong ke pembiayaan.

3. Prinsip Jual Beli (Al-Tijarah)

Prinsp jual beli merupakan sistem yang menerapkan tata cara dari jual beli, yang dimana bank akan membelikan terlebih dahulu barang yang dibutuhkan nasabah atau mereka akan mengangkat nasabah untuk menjadi agen bank untuk melalukan pembelian suatu barang dengan atas nama bank, lalu bank tersebut akan menjualnya kepada si nasabah denga harga yang sejumlah dengan harga beli tersebut dan 
ditambah dengan margin atau keuntungan. Pada prinsip ini bentuk produknya dapat berupa, Murabahah, Salam dan Istishna.

4. Prinsip Sewa (Al-ljarah)

Secara garis besar prinsip ini terbagi menjadi dua jenis, yaitu:

1) Jjarah (sewa murni), contohnya penyewaan alat-alat berat dan produl lainnya (operating lease). Di dalam tekni perbankan sendiri, bank akan membelikan terlebih dahulu alat yang dibutuhkan oleh nasabah lalu bank akan menyewakannya dengan kesepakatan mengenai waktu dan tentunya sesuai kesepakatan nasabah.

2) Bai Al-Takjiri (ljarah Al Muntahiya Bit Tamlik)

Ini merupakan penggabungan dari sewa dan beli, yang dimana penyewa memiliki hak untuk dapat memiliki barang pada masa akhir sewa (finansial lease)

5. Prinsip Jasa atau fee (Al-Ajr Walumullah) Pada prisip ini meliputi dari semua layanan yang non pembiayaan dari bank. Bentuk produk pada prinsip ini yaitu Bank garansi, Kliring, Inkaso, jasa, Transfer dan lainnya. 
Transaksi atau akad pelengkap yang telah dikembangkan sebagai akad pelayanan pada jasa perbankan, yakni:

1) Al-Hiwalah (Alih Utang Piutang). Yaitu transaksi pengalihan utang piutang. Di dalam praktek perbankan sendiri fasilitas ini biasanya untuk membantu si supplier untuk mendapatkan modal secara tunai agar bisa meneruskan proses produksinya. Bank sendiri mendapatkan ganti biayannya atas jasa pemindahan piutang.

2) Rahn (Gadai), fungsinya untuk memberikan jaminan pembayaran kembali pada bank dalam memberikan suatu pembiayaan. Barang yang akan digadaikan memiliki ketentuan dan wajib memeuhi kriterianya sebagai berikut ini: barang harus milik dari nasabah itu sendiri, Jelas ukuran, nilai dan sifatnya yang ditentukan dengan berdasarkn nilai riil, Dapat dimiliki atau dikuasai oleh bank tetapi tidak boleh dimnfaatkan oleh bank.

3) Al Qard bisa disebut dengan pinjaman kebaikan, pada pinjaman ini digunakan untuk membantu dari keuangan nasabah dengan secara cepat dan berjangka pendek. Pada produk ini umumnya digunakan pada usaha kecil dan untuk 
membantu keperluan sosial lainnya. Dana diperoleh dari Zakat, Infaq dan Shadaqah.

4) Wakalah, nasabah akan memberikan kuasa pada bank untuk mewakilinya untuk melakukan pekerjaan jasa yang tertentu. Contohnya, transfer, dll.

5) Kafalah, bank garansi yang digunakan untuk menjamin pembayaran. Bank dpat menajukan syarat pada nasabah untuk menempatkan dananya untuk menggunakan fasilitas ini sebagai rahn. Prinsip wadiah dapat digunkan bank tersebut untuk menerima dana. Dan bank juga dapat memperoleh ganti biaya atas jasa yang diberikan.

Dari penjelasan diatas, di dalam manajemen operasional bank syariah manajer harus wajib berpedoman pada 5 prinsip tersebut. Dan secara operasionalnya dapat dikelompokkan menjadi 3 yakni Produk penghimpunan dana, Poduk Penyaluran Dana dan Produk Jasa Perbankan yang akan dijelaskan selanjutnya. ${ }^{4}$

\section{Prinsip Manajemen Operasional Bank Syariah}

4 Ibid. 
Bank Syariah merupakan suatu lembaga keuangan yang fungsinya untuk memperlancar setiap mekanisme ekonomi pada sektor riil melalu aktivitas investasi maupun jual beli dan juga memberikan pelayanan berupa jasa simpanan perbankan bagi nasabah. Berkaitan dengan aktivitas tersebut maka setiap aktivitas perbankan perlu untuk dimanajemi. Untuk memanajemi perbankan yang berkaitan dengan kerangka pemikiran di atas harus berpedoman sesuai prinsip-prinsip dasar bank syariah sesuai juga dengan lembaga keuangan lainnya yang harus menerapkan setiap ketentuan atau prinsip operasional yang berlandaskan dalm Al-Quran dan AlHadits.

Bank syariah yang ada di Indonesia, didasari pada Undang-Undang nomor 21 tahun 2008 pasal 2 perbankan syariah dalam melakukan kegiatan atau mengoperasionalkan usahanya berasaskan prinsip syariah, demokrasi ekonomi dan prinsip kehati-hatian. Untuk itu manajer harus melakukan prinsip:

1) Prinsip syariah

Dalam melakukan transaksi pelaku yaitu bank harus meninggalkan lima unsur yaitu riba, gharar dan maisir, haram, dan kedhaliman. Penjelasannya sebagai berikut:

\section{a) Riba}

Pada prinsip ini didasarkan pada firman allah 


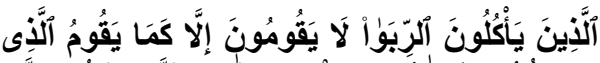

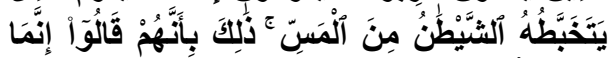

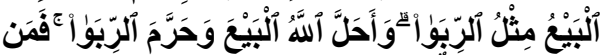

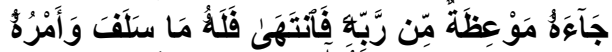

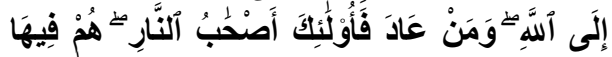
خَلِدُونَ

Artinya: "Orang-orang yang makan (mengambil) riba tidak dapat berdiri melainkan seperti berdirinya orang yang kemasukan syaitan lantaran (tekanan) penyakit gila. Keadaan mereka yang demikian itu, adalah disebabkan mereka berkata (berpendapat), sesungguhnya jual beli itu sama dengan riba, padahal Allah telah menghalalkan jual beli dan mengharamkan riba. Orang-orang yang telah sampai kepadanya larangan dari Tuhannya, lalu terus berhenti (dari mengambil riba), maka baginya apa yang telah diambilnya dahulu (sebelum datang larangan); dan urusannya (terserah) kepada Allah. Orang yang kembali (mengambil riba), maka orang itu adalah penghuni-penghuni neraka; mereka kekal di dalamnya." 
Larangan pada riba dan anjuran untuk membayar zakat, berinfaq, shadaqah dan sebagainya merupakan suatu kewajiban bagi mereka yang mempunyai kelebihan dana untuk menjalankan suatu usaha atau berinvestasi, sehingga dapat membuka lowongan kerja bagi orang lain dan akan berdampak besar bagi peningkatan ekonomi masyarakat.

b) Gharar

Gharar yaitu sesuatu yang mempunyai sifat tidak pasti. Transaksi gharar merupakan transaksi yang mengandung unsur ketidakpastian atau ketidaktahuan antara dua pihak yang melakukan transaksi, yang berkaitan dengan shigad atau objek akad.

\section{c) Maysir}

Melakukan transaksi di bank harus menghindari unsur judi (maysir) yang merupakan suatu bentuk objek yang mempunyai arti sebagai tempat untuk memudahkan sesuatu. Dapat diartikan memudahkan karena jika seseorang yang harusnya melalu perjalanan dengan susah payah akan tetapi mencari jalan yang lebih mudah atau jalan pintas dengan mempunyai 
harapan sesuai yang dikehendakinya.

Meskipun jalan pintas yang dilalui telah bertentangan dengan aturan syariah.

Hal ini terdapat dalam Al-Quran surat Al Maidah ayat 90-91:

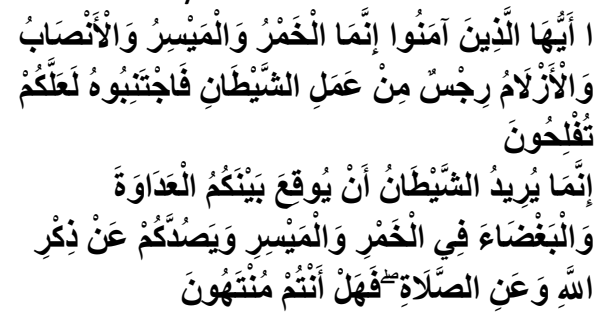

Artinya:" Hai orang-orang yang beriman, sesungguhnya (meminum) khamar, berjudi, (berkorban untuk) berhala, mengundi nasib dengan panah, adalah termasuk perbuatan syaitan. Maka jauhilah perbuatan-perbuatan itu agar kamu mendapat keberuntungan.

Sesungguhnya syaitan itu bermaksud hendak menimbulkan permusuhan dan kebencian di antara kamu lantaran (meminum) khamar dan berjudi itu, dan menghalangi kamu dari mengingat Allah dan sembahyang; maka berhentilah kamu (dari mengerjakan pekerjaan itu)."

d) Haram 
Haram merupakan sesuatu transaksi yang objeknya dilarang dalam syariah, baik dalam hal zatnya, haram cara untuk memperolehnya ataupun haram dalam cara memanfaatkannya.

\section{e) Kedhaliman}

Merupakan suatu prinsip yang tidak menimbulkan kedhaliman atau ketidakadilan terhadap pihak lain.

2) Prinsip Demokrasi Ekonomi

Merupakan suatu kegiatan ekonomi yang syariah dan mengandung nilai-nilai keadilan, kebersamaan, kemerataan dan juga kemanfaatan. Dean demikian pula di dalam prinsip demkrasi ini tidak ada terjadinya seseorang yang mengekploitasi orang lain dan diharukan untuk saling tolong menolong dan membangun kemitraan atau kerjasama di dalam kehidupan berekonomi yang saling menguntungkan.

3) Prinsip Kehati-hatian

Salah satu pedoman yang wajib diberlakukan dan dijalankan yang berguna mewujudkan sisitem perbankan yang sehat, kuat dan juga efisien yang sesuai dengan peraturan undangundang. Manajer di bank dan juga pengelola satu sama lain harus melaksanakan prinsip 
kehati-hatian ini sehingga dapat mencapai tujuan syariat.

\section{Prinsip Operasional Bank syariah}

Perbankan syariah sendiri menjalankan fungsi-fungsi operasionalnya meliputi penghimpunan, penyaluran, dan jasa. Agama Islam dalam memberikan dasar-dasar dari pedoman operasional perbankan bank syariah dapat menjalankan prinsip-prinsipnya, sebagai berikut: ${ }^{5}$

1. Produk Pembiayaan (financing)

a. Pembiyaan ekuitas (equity financing)

b. Kontrak Mudharabah

c. Kontrak Musyarakah

d. Debt Financing

e. Kontrak Murabahah

f. Kontrak bai al-istishna

g. Kontrak bai as-salam

h. Kontrak qardh

i. Kontrak al-ljarah

2. Produk Penghimpunan dana (funding)

a. Rekening tabungan prinsip wadiah atau mudharabah (saving account)

b. Rekening Koran dengan prinsip wadiah

${ }^{5}$ G Danupranata, Buku Ajar Manajemen Perbankan Syariah Gita Danupranata, Salemba Empat (Jakarta: Salemba Empat, 2013). 

c. Rekening Mudharabah muqayyadah untuk investasi khusus
d. Rekening Mudharabah mutlaqah untuk investasi umum

3. Produk jasa
a. Jaminan peminjaman (letter of credit) dengan prinsip mudharabah, musyarakah atau wakalah.
b. Transfer dan Prinsip Wakalah
c. Garansi bank Prinsip Wakalah
d. Jual beli valuta asing atau valas

\section{Peranan dan Fungsi Bank Syariah}

Di negara Indonesia, mayoritas penduduknya beragama islam yang menuntut adanya sistem yang telah paten untuk mengatur kegiatan dalam kehidupannya. Maka dari itu, Sistem Lembaga Keuangan atau khususnya disebut sebagai suatu aturan yang telah menyangkut dari aspek keuangan dalam sistem keuangan suatu negara, telah menjadi bagian atau instrumen yang penting guna memperlancar jalannya pembangunan di suatu bangsa. ${ }^{6}$

Di bidang perbankan khususnya, sejarah telah merekam, berdirinya De Juvache Bank di tahun 1872, telah tertanam nilai-nilai dari sistem perbankan yang hingga saat ini telah menjadi tradisi dan sudah

${ }^{6}$ Nawawi, Perbankan Syariah. 
tertanam di dalam masyarakat indonesia, dan yang terpenting pada umat islam. Terlalu sulit untuk menghilangkn tradisi tersebut, tetapi apakah itu akan berlangsung secara terus menerus. Solusi alternatif apa yang mungkin dapat dijalankan?

Pada abad XX terjadilah kebangkitan umat islam, hal itu menjadi kabar yang sangat menggembirakan karena terjadi di segala aspek. Pada sistem keungan sendiri, telah berkembangnya pemikiran yang tujuannya reorientasi sistem keuangan yaitu dengan dihapuskannya instrumen utamanya yaitu bunga. Dilakukannya hal tersebut dengan tujuan agar tercapainya kesesuaian pelaksanaan prinsip-prinsip ajaran islam yang didalamnya terkandung kejujuran, kebajikan dan dasar-dasar keadilan.

Lahirnya Undang-Undang nomor 7 tahun 1992 yang direvisi melalui Undang-Undang Nomor 10 tahun 1998 telah mengkui keberadaan dan fungsi Bank bagi hasil atau Bank Islam. Dengan begitu, bank ini adalah bank yang operasionalnya menggunakan prinsip bagi hasil.

Berkaitan dengan peranan sesuatu, hal itu tidak dapat dipisahkan dengan fungsi dan kedudukan sesuatu itu. Peranan bank islam dintaranya yaitu:

1. Menjernihkan operasional dari perbankan syariah sehingga dapat meningkatkan kepercayaan dari masyarakat

2. Agar dapat meningkatkan kesadaran umat muslim terhadap perbankan syariah, 
hingga akan berdampak pada segmentasi dan pangsa pasar yang lebih luas.

3. Menjalin kerjasama dengan ulama, karena peran ulama sangat penting dan sangat dominan bagi umat muslim, khususnya di Indonesia.

Dari hasil beberapa penelitian telah menunjukkan bahwasannya lembaga keuangan Bank ataupun Non Bank yang sifatnya formal dan beroperasi di daerah pedesaan, pada umumnya tidak dapat menjangkau semua lapisan masyarakat yang berasal dari golongan ekonomi menengah ke bawah. Terutama tidak mampunya tersebut dalam sisi penanggungan risiko dan biaya operasi bank tersebut. Dan inilah yang menjadi penyebab dari adanya kekosongan pada segmen keuangan di pedesaan. Imbasnya70-90\% kekosongan diisi dari lembaga keuangan yang non formal, termasuk para rentenir yang menggunakan suku bunga yang memberatkan atau terlampau tinggi. Untuk menyelesaikannya diperlukan adanya suatu lembaga yang mampu menjadi penengah. Salah satu wujud nyata yaitu dengan membangun Bank umum syariah, BPR syariah, dn BMT (Baitul Mal wa Tamwil) yakni Imbaga keuangan tersebut operasionalnya menggunakan prinsip bagi hasil. ${ }^{7}$

${ }^{7}$ lbid. 
Melalui berbagai pembiayaan yang dikeluarkan oleh bank islam diharapkan dapat memberikan sumbangsi terhadap pertumbuhan ekonomi masyarakat. Dengan pembiayaan ini pula diharapkan bank islam dapat menjadi mitra dengan para nasabah, sehingga hubungan yang terjalin bank islam dengan nasabah tidak akan lagi menjadi sebagai kreditur dan debitur tetapi terjalin kemitraan.

Secara tertentu peranan bank syariah dengan nyata dapat diwujudkan melalui aspek-aspek berikut ini:

1) Menjadi pemberdaya ekonomi semua umat dan cara beroperasinya secara transparan, Artinya setiap pengelolaan dari bank syariah harus berdasarkan sesuai visi ekonomi kerakyatan dan usaha ini akan terwujud apabila setiap mekanisme dilaksanakan secara transparan.

2) Menjadi pemersatu nasionalisme, Artinya bank syariah dapat dijadikan sebagai fasilitator aktif untuk terbentuknya berbagai jaringan usaha ekonomi kerakyatan. Dan bank syariah perlu mencontoh keberhasilan dari Sarekat Dagang Islam, dan kemudian keberhasilannya dapat diterpkan di berbagai aspek pada masa kini yang meliputi nasionalis, demokratis, religius, ekonomis. 
3) Dapat dijadikan sebagai pendorong spekulasi di pasar keuangan, Artinya bank syariah sendiri dapat mendorong adanya transaksi produktif dana masyarakat. Dengan begitu spekulasi dapat ditekan.

4) Dapat memberikan return yang lebih baik. Artinya di bank syariah sendiri pada setiap investasinya tidak bisa memberikan janji yang pasti untuk pemberian return (keuntungan) yang diberikan kepada investor. Maka dari itu bank syariah sendiri harus mampu untuk memberikan return yang jauh lebih baik dari bank konvensional. Di lain itu nasabah dari pembiayaan akan memberikan bagi hasil sesuai keuntungan yang akan diperolehnya. Maka dari itu penguaha harus bersedia untuk memberikan keuntungan yang cukup tinggi kepada bank syariah.

5) Peningkatan ekonomis mobilisasi dana, artinya dengan adanya produk almudharabah al muqayyadah, bank diberikan kebebasan untuk melakukan investasi dari dana yang disetor oleh investor, maka dari itu bank sebagai financial arranger memperoleh komisi atau bagi hasilnya, bukan karena bunga. 
6) Mendorong adanya pemerataan pendapatan, artinya fungsi dari bank syariah itu sendiri bukan hanya untuk mengumpulkan dana pihak ketiga, tetapi dapat juga untuk mengumpulkan dana Zakat, Infaq, dan Shadaqah (ZIS). Dana ZIS disalurkan melalui pembiayaan Qardul Hasan, yang dapat mendorong pertumbuhan ekonomi masyarakat. Dan pada akhirnya terjadi pemeratan ekonomi.

7) Uswah hasanah (teladan yang baik) Impleentasi moral dalam setiap penyelenggaraan usaha dari bank.

Dikarenakan sifatnya yang sebagai bank. Bank Syariah harus dan wajib memposisikan diri sebagai Uswatun hasanah dalam setiap implementasi moral dan setiap etika bisnis atau melaksanakan setiap etika dan moral dalam aktivitas ekonomi.

Sedangkan dalam bisnis dan pembangunan bank syariah memiliki fungsi sebagai penghimpun dan penyalur dana masyarakat. Bank merupakan lembaga keuangan yang sangat penting sebagai pendorong pertumbuhan ekonomi masyarakat, karena bank adalah:

1) Pengumpul dana yang berasal dari Surplus Spending Unit dan Penyalur dana kepada Defisit Spending Unit (DSU) 
2) Tempat untuk menabung yang efektif dan produktif bagi setiap masyarakat

3) Sebagai pelaksana dan untuk memperlancar setiap lalu lintas pembayaran secara praktis dan ekonomis

4) Sebagai penjamin penyelesaian perdagangan dengan diterbitkannya $\mathrm{L} / \mathrm{C}$

5) Penjamin penyelesaian setiap proyek dengan menerbitkan bank garansi.

Bank syariah berfungsi sebagai lembaga perantara, pedoman yang mendasari setiap kegiatan yang dilkukan bank syariah yaitu kepercayaan masyarakat, maka dari itu pula bank syariah disebut juga sebagai lembaga kepercayaan masyarakat yang mempunyai ciri-ciri utamanya sebagai berikut:

1) Bank syariah dalam menerima simpan dari Surplus Spending Unit (SSU) telah memberikan pernyataan tertulis yang menjelaskan telah menerima simpanan dengan jumlah dan juga jangka waktu tertentu.

2) Bank syariah dalam menyalurkan dana kepada Defisit Spending Unit (DSU) tidak selalu anggunan yang berupa barangb yang sebagai jaminan atas penyaluran dana yang diberikan oleh DSU yang telah memiliki reputasi yang baik. 
3) Bank syariah dalam melakukan kegiatan operasinalnya lebih banyak menggunakan dana yang berasal dari dana masyarakat yang terkumpul daripada menggunakan modal dan pemilik atau pemegang saham.

Bank juga harus bermanfaat bagi setiap pembangunan ekonomi nasional sesuai dengan fungsinya sebagai agent of development yang dalam rangka mewujudkan pemerataan pertumbuhan ekonomi dan stabilitas, selain itu bank sebagai lembaga kepercayaan juga dituntut untuk selalu memperhatikan kepentingan msyarakat daripada kepentingan bank sendiri dalam rangka mengembangkan setiap usahanya.

\section{Rangkuman}

Bank Syariah dimana aktivitasnya mengacu pada hukum Islam dan tidak menerapkan bunga serta tidak membayar bunga kepada phak manapun. Imbalan bank syariah yang diterima maupun dikeluarkan kepada nasabah sesuai dengan akad dan perjanjian yang disetujui oleh kedua pihak.

perkembagan perbankan syariah di Indonesia didukung secara intensif oleh beberapa lembaga, yaitu Dewan Syariah Nasional-Majelis Ulama Indonesia (DSN-MUI), Bank Indonesia (BI), dan Komite Akuntansi Syariah-Ikatan Akuntan Indonesia (KAS-IAI). 
Dewan Syariah Nasional (DSN) yaitu bagian dari MUI yangmenetapkan dan membuat kebijakan (fatwa) terkait keuangan syariah. Sedangkan Komite Akuntansi Syariah (KAS) merupakan komite yang dibentuk oleh IAI untuk merumuskan standar akuntansi syariah.

\section{E. Studi Kasus}

1. Jelaskan definisi lembaga keuangan syariah menurut Dewan Syariah Nasional!

2. Jelaskan empat prinsip hukum Muamalat!

3. Berilah tiga contoh transaksi yang haram zatnya yang sangat mungkin biasa dilakukan di bank konvensional!

4. Jelaskanlah perbedaan antara tadlis dan gharar!

5. Berilah contoh transaksi yang sangat mungkin terjadi di masyarakat, akan tetapi masuk dalam kategori tadlis dalam kategori harga, kualitas, kuantitas dan waktu penyerahan!

6. Berilah contoh transaksi yang sangat mungkin terjadi di masyarakat, akan tetapi masuk dalam kategori gharar dalam kategori harga, kualitas, kuantitas dan waktu penyerahan!

7. Jelaskan apa yang dimaksud dengan riba, dan berilah 3 contoh bisnis yang ada di masyarakat yang beroperasi dengan konsep riba!

8. Jelaskan perbedaan antara bai' najasy dengan bai' ittikhar dan berilah masing-masing 2 contoh yang mungkin masih ada di masyarakat! 
9. Jelaskan apa yang dimaksud dengan maysir dan berilah 3 contoh praktik maysir yang mungkin masih ada di masyarakat!

10. Jelaskan rukun sahnya akad! 


\section{BAB II}

\section{SISTEM PENGELOLAAN DAN OPERASIONAL BANK SYARIAH}

\section{Kompetensi Dasar}

Setelah mempelajari bab ini, diharapkan membentuk mahasiswa yang kompeten dalam hal berikut :

1. Mampu menyebutjelaskan sistim operasional perbankan syariah meliputi aspek penghimpunan, penyaluran dan jasa keuangan.

2. Mampu menyebutjelaskan prinsip operasional perbankan syariah.

\section{Indikator}

Beberapa indikator yang ada dalam bab ini, sebagai berikut :

1. Pemahaman sistim operasional perbankan syariah secara umum.

2. Pemahaman terhadap mekanisme penghimpunan dana bank syariah

3. Pemahaman terhadap mekanisme pennyaluran dana bank syariah

4. Pemahaman terhadap mekanisme jasa keuangan syariah

\section{Materi Pokok}

Materi utama pada bab ini adalah Sistim Operasional

Perbankan Syariah yaitu : 1. Penghimpunan dana, 2.

Penyaluran dana, 3. Jasa Keuangan. 


\section{A. Azas Operasional Bank Syariah}

Dalam kegiatan operasional bank syariah harus memenuhi azas-azas transaksi syariah yang telah ditentukan sebagai berikut :

1. Prinsip persaudaraan (ukhuwah)

Transaksi syariah menjunjung tinggi nilai kebersamaan dan sharing economic sehingga seseorang tidak boleh memperoleh keuntungan diatas kerugian orang lain. Ukhuwah ini berdasar pada prinsip saling menolong, mengenal, memahami dan saling bersinergi serta beraliansi ${ }^{8}$.

2. Prinsip keadilan ('adalah)

Yaitu menempatkan sesuatu pada tempatnya dan memberikan sesuatu hanya kepada orang yang berhak. Prinsip keadilan ini dalam kegiatan usaha yang melarang adanya unsure berikut ${ }^{9}$ :

a. Riba

Esensinya ialah bertambahnya nilai harga pada piutang yang disyaratkan dalam transaksi non-tunai seperti murabahah tangguh dan pada

\footnotetext{
${ }^{8}$ Wiroso, Produk Perbankan Syariah (Jakarta: LPFE Usakti, 2011).

${ }^{9}$ Ascarca, Akad Dan Produk Bank Syariah (Jakarta: Raja Grafindo, 2007).
} 
transaksi pinjam-meminjam uang. Serta pada transaksi pertukan uang yang termasuk barang ribawi.

b. Gharar

Gharar yaitu sesuatu yang mempunyai sifat tidak pasti. Transaksi gharar merupakan sebuah transaksi yang telah mengandung unsur ketidakpastian atau ketidaktahuan antara dua pihak yang melakukan transaksi, yang berkaitan dengan shigad atau objek akad.

c. Maysir

Segala sesuatu transaksi yang bersifat spekulatif dan terdapat unsur perjudian.

d. Haram

Sesuatu transaksi yang objeknya dilarang dalam syariah, baik dalam hal zatnya, haram cara untuk memperolehnya ataupun haram dalam cara memanfaatkannya.

e. Kezaliman

Merupakan menempatkan sesuatu tidak pada tempatnya. Kezaliman juga termasuk tidak memberikan sesuatu sesuai kualitas, jumlah barang maupun ukuran barang. 
Unsur ini dapat menimbulkan kemudharatan bagi masyarakat dan bagi para pihak yang terikat dalam transaksi tersebut.

3. Prinsip kemaslahatan (maslahah)

Prinsip ini wajib mengandung unsur kepatuhan secara syariah, membawa kebaikan dan bermanfaat bagi semua aspek serta tidak menimbulkan kemudhratan. Transaksi syariah bermaslahah harus memenuhi unsur maqashid syariah berupa pemeliharaan terhadap:

a. Aqidah, keimanan dan ketaqwaan (Ad-dien)

b. Akal (aql)

c. Keturunan (nasl)

d. Keselamatan jiwa (nafs)

e. Harta benda (Al-maal)

4. Prinsip keseimbangan (tawazun)

Keseimbangan pada aspek material dan spiritual, sector keuangan dan sector riil, bisnis dan social, serta aspek pelestarian dan pemanfaatan. Transaksi syariah tidak boleh hanya memaksimalkan keuntungan untuk kepentingan pribadi melainkan mementingkan keuntungan yang dapat dirasakan oleh semua pihak yang bersangkutan bahkan masyarakat sekitar.

5. Prinsip universalisme (syumuliyah) 
Dilakukan oleh semua pihak yang tidak membedakan mengenai suku, ras, agama dan golongan, harus sesuai dengan kerahmatan semesta (rahmatan lil alamin) ${ }^{10}$.

Berdasarkan pasal 2 UU no.21 tahun 2008 mengenai asas operasional bank syariah menyebutkan bahwa perbankan syariah melakukan suatu transaksi harus berazaskan prinsip syariah, prinsip kehati-hatian dan demokrasi ekonomi ${ }^{11}$.

1) Prinsip Demokrasi Ekonomi

Merupakan suatu kegiatan ekonomi syariah yang mengandung nilai-nilai keadilan, kebersamaan, kemerataan dan juga kemanfaatan. Dalam prinsip demokrasi ekonomi ini tidak ada terjadinya seseorang yang mengeksploitasi orang lain dan diwajibkan untuk saling tolong menolong dan membangun kerjasama di dalam kehidupan berekonomi yang saling menguntungkan.

2) Prinsip Kehati-hatian

Salah satu pedoman yang wajib diberlakukan dan dijalankan adalah mewujudkan sistem

${ }^{10}$ Wiroso, Produk Perbankan Syariah.

${ }^{11}$ Muammar Khaddafi et al., Akuntansi Syariah Meletakkan NilaiNilai Syariah Islam Dalam IImu Akuntansi (Medan: Madenatera, 2016). 
perbankan yang sehat, kuat dan juga efisien yang sesuai dengan peraturan undangundang. Semua pihak yang mengelola bank satu sama lain harus melaksanakan prinsip kehati-hatian ini sehingga dapat mencapai tujuan syariat.

\section{B. Produk Penghimpunan Dana}

Dalam kegiatan penghimpunan dana pada bank syariah menggunakan prinsip-prinsip sebagai berikut:

1. Prinsip Al-Wadi'ah

Wadi'ah adalah titipan atau simpanan murni dari pihak penitip yang memiliki aset atau harta (muwaddi') kepada pihak penyimpan titipan (mustaudda') baik secara perseorangan maupun badan hukum yang harus dijaga dan dapat diambil kapanpun sesuai kehendak si pemilik harta atau penitip. Pada bank syariah, produk wadi'ah ini dikembangkan menjadi dua jenis yaitu : (1) Wadiah yad amanah (tangan amanah) dimana penerima titipan tidak ada kewenangan untuk menggunakan barang/dana yang dititipkan tersebut dan ada beban biaya penitipan. dan (2) Wadi'ah yad Dhamanah (tangan penanggung) dimana penerima titipan boleh menggunakan barang/dana titipan dtanpa adanya 
kewajiban memberi imbalan kepada penitip tetapi boleh memberikan bonus ${ }^{12}$.

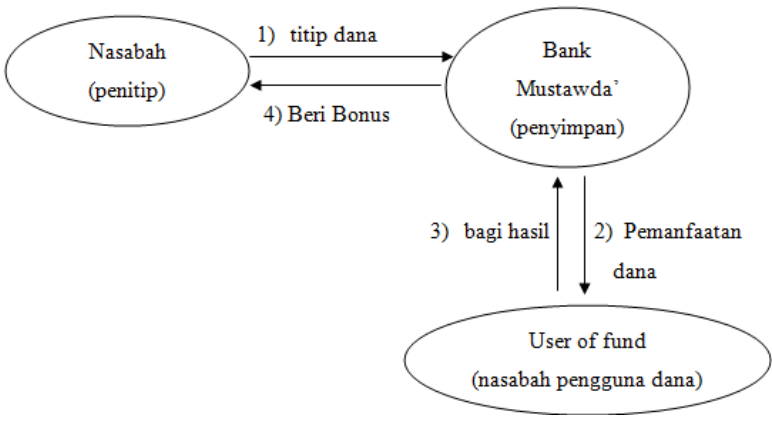

Gambar 1. Skema wadi'ah yad dhamanah

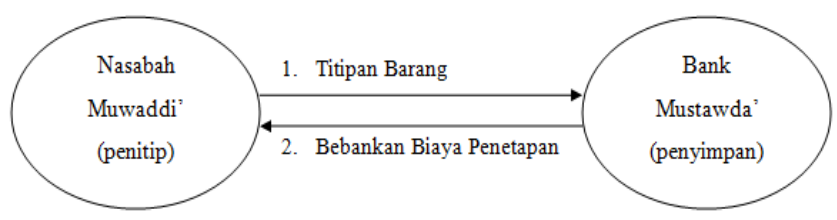

Gambar 2. Skema wadia'ah yad amanah

Teknis Al-Wadiah dalam perbankan syariah sebagai berikut :

a. Prinsip Al-Wadi'ah yang digunakan dalam perbankan ialah wadiah yad

12 Khaerul Umam, Manajemen Perbankan Syariah (Bandung: CV Pustaka Setia, 2013). 
dhamanah yang diterapkan pada produk rekening giro.

b. Karena bank menerapkan wadi'ah yad dhamanah, maka hukumnya sama dengan qardh dimana bank bertindak sebagai peminjam uang dan nasabah sebagai pemilik dana (yang memiliki uang).

2. Prinsip Al-Mudharabah

Mudharabah adalah akad kerjasama usaha antara dua pihak, dimana pihak pertama bertindak sebagai shahibul maal (pemilik dana) dan pihak kedua bertindak sebagai mudharib (pengelola dana). Dana tersebut digunakan oleh pihak bank untuk melakukan pembiayaan mudharabah atau ijarah. Hasil usaha dari kedua transaksi pembiayaan tersebut akan dibagihasilkan berdasarkan nisbah yang telah disepakati. Jika bank menggunakan dana tersebut pada pembiayaan mudharabah maka pihak bank bertanggungjawabatas kerugian yang terjadi ${ }^{13}$.

${ }^{13}$ Nawawi, Perbankan Syariah. 


\section{Produk Penyaluran Dana}

Dalam praktek perbankan syariah, produk penyaluran dana ini dapat dikembangkan menjadi 3 model, yaitu

\section{Prinsip Jual- beli}

Jual beli berasal dari kata "buyu', jama' dari bai'". Jual beli atau perniagaan adalah tukar menukar suatu barang saling rela (ridha) atau memindahkan kepemilikan barang dengan imbalan. Terdapat tiga produk pada prinsip ini, yaitu:

a. Bai' Al-Murabahah

Murabahah merupakan kegiatan jual beli pada suatu harga pokok ditambah dengan keuntungan yang telah disepakati antara bank dengan nasabah. Dalam Bai' Al- Murabahah ini, penjual harus menyebutkan terlebih dulu mengenai harga pembelian barang kepada pembeli, kemudian mensyaratkan laba pada nominal tertentu.

Teknis pada perbankan syariah sebagai berikut ${ }^{14}$ :

1) Pihak bank bertindak sebagai penjual sedangkan nasabah

${ }^{14}$ Heri Sudarsono, Bank Dan Lembaga Kuangan Syariah (Yogyakarta: EKONISIA, 2012). 
sebagai pembeli. Harga jual barang merupakan harga beli pihak bank dari produsen (pembuat/took) ditambah keuntungan (mark-up).

2) Harga jual tersebut harus dicantumkan dalam perjanjian jual beli dan jika telah disepakati tidak dapat berubah selama akad berlangsung.

3) Pada transaksi murabahah ini apabila barang telah ada segera disegerakan kepada nasabah. Sedangkan pembayarannya dengan cicila atau tangguh (bitssaman ajil).

b. Bai' As-Salam

Salam merupakan kegiatan jual beli barang dengan pembayaran di awal dan barang diserahkan secara tangguh. Yang terutama dalam transaksi ini adalah harus mengetahu secara jelas mengenai brang yang akan dipesan dari jenis, kualitas, dan jumlah barang. 
Teknis pada perbankan syariah sebagai berikut ${ }^{15}$ :

1) Transaksi salam ini merupakan jual beli yang barangnya belum ada sehingga barang itu diserahkan dikemudian hari atau tangguh sedangkan pembayaran dilakukan secara tunai.

2) Saat barang telah ada di pihak bank maka bank akan menjualnya kembali ke nasabah drcara tunai atau cicilan dengan harga jual yang telah ditetapkan.

3) Apabila bank menjual ke nasabah secara tunai biasanya disebut sebagai pembiayaan talangan. dan apabila secara cicilan maka bank dan nasabah harus menyepakati harga jual dan jangka waktu pembayaran.

4) Harga jual yang telah disepakati dan dicantumkan

${ }^{15}$ lbid. 
dalam akad tidak bisa berubah.

C. Bai' Al-Istishna'

Bai' Al-Istishna' adalah bentuk khusus dari bai' as-salam, sehingga semua ketentuan dalam istishna' mengikuti aturan salam.namun bai' al-istishna' pembayarannya dapat dilakukan diawal atau secara angsuran atau di akhir. Biasanya akad ini digunakan pada bidang manufaktur.

\section{Prinsip sewa (ljarah)}

ljarah merupakan akad pemnidahan hak guna atas suatu barang atau jasa tanpa diikuti pemindahan kepemilikan melalui pembayaran upah sewa. Dalam perbankan syariah, ijarah adalah lease contract yang artinya lembaga keuangan syariah menyewakan peralatan kepada nasabah berdasar atas beban biaya yang telah ditentukan sebelumnya.

Teknis pada perbankan syariah sebagai berikut :

1) Transaksi ijarah ditandai dengan adanya pemindahan manfaat. Prinsip ijarah sama dengan prinsip jual beli, namun berbeda pada objek transaksi yaitu pada ijarah objeknya berupa 
jasa sedangkan pada jual beli berupa barang.

2) Diakhir masa sewa, pihak bank boleh menjual barang yang disewa tersebut kepada nasabah yang berarti disebut sebagai al-ijarah al-muntahiyah bittamlik (sewa yang diikuti dengan perpindahan kepemilikan).

3) Harga jual dan harga sewa disepakati oleh kedua pihak pada awal akad.

\section{Prinsip bagi hasil}

Pada pirinsip bagi hasil ini terdiri dari atas 2 produk, yaitu:

a. Al-Musyarakah

Kata lain dari musyarakah adalah syirkah atau sharikah. Musyarakah adalah akad kerjasama antara dua pihak atau lebih untuk melakukan suatu usaha tertentu dimana masing-masing pihak berkontribusi dana dengan kesepakatan bahwa risiko maupun keuntungan akan ditanggung bersama sesuai dengan kontribusi dan kesepakatan.

Dalam transaksi ini semua modal disatukan dan dikelola bersama-sama, dan pemilik modal 
berhak atas kebijakan usaha yang akan dijalankan. Musyarakah tidak boleh melakukan tindakan ${ }^{16}$ :

1) Menggabungkan modal dengan harta pribadi.

2) Melakukan proyek musyarakah dengan pihak lain tanpa izin dari pemilik dana lainnya.

3) Dianggap mengakhiri apabila meninggal dunia, menarik diri dari perserikatan dan menjadi tidak cakap hukum.

b. Al-Mudharabah

Mudharabah adalah akad kerjasama usaha antara dua pihak, dimana pihak pertama bertindak sebagai pemilik dana (shahibul maal) dan pihak kedua bertindak sebagai pengelola dana (mudharib). Dalam transaksi ini, keuntungan dibagi sesuai kesepakatan bersama yang telah tertuang dalam kontrak perjanjian, sedangkan kerugian ditanggung oleh pemilik dana selama kerugian tersebut bukan akibat dari pengelola. Apabila kerugian

${ }^{16}$ Nawawi, Perbankan Syariah. 
diakibatkan oleh si pengelola, maka pengelola wajib bertanggung jawab atas kelalaiannya.

Berdasarkan kewenangan pengelola (mudharib) dalam pengelolaan modal yang diberikan oleh shahibul maal, transaksi ini dikategorikan menjadi:

1) Mudharabah Mutlaqah

Mudharabah Mutlaqah adalah akad kerjasama yang dimana si pengelola (mudharib) diberi kuasa penuh untuk mengelola modal usaha yang tidak membatasi atas tempat, jenis, dan tujuan usaha. Penerapan transaksi ini dalam perbankan yaitu dapat berupa produk tabungan mudharabah dan deposito mudharabah.

2) Mudharabah Muqayyadah on Balance Sheet

Jenis transaksi mudharabah ini adalah simpanan khusus (restricted investment) dimana shahibul maal berhak menetukan syarat tertentu yang harus dilaksanakan oleh 
pihak bank sebagai pengelol (mudharabah $)^{17}$.

Jenis simpanan ini pihak pengelola atau bank wajib memberitahukan mengenai nisbah dan tata cara pembagian keuntungan kepada shahibul maal. Dan bank harus menerbitkan bukti simpanan khusus atau tanda penyimpanan (sertifikat) deposito untuk diberikan kepada shahibul maal (nasabah) serta bank wajib memisahkan dana tersebut dari rekening lain.

3) Mudharabah Muqayyadah off Balance Sheet Jenis transaksi mudharabah ini adalah dimana penyaluran dananya Ingsung kepada pelaku usaha. Bank sebagai perantara yang mempertemukan antara pemilik dana dengan pelaku usaha. Pemilik dana tersebut

${ }^{17}$ Sudarsono, Bank Dan Lembaga Kuangan Syariah. 
dapat menentukan syaratsyarat mengenai kegiatan usaha yang akan dibiayai tersebut ${ }^{18}$.

Bank harus menerbitkan bukti simpanan khusus untuk diberikan kepada shahibul maal (nasabah) serta bank wajib memisahkan dana tersebut dari rekening lain dan mencatat pada pos tersendiri. Dana dari transaksi ini harus disalurkan langsung kepada pihak yang telah diamanatkan oleh shahibul maal. Dan bank berhak menerima komisi atas jasa perantara kedua pihak.

\section{Akad Pelengkap}

Untuk mempermudah kegiatan transaksi bank syariah dengan para nasabanya, diperlukan akad pelengkap atas akad-akad yang telah tersedia pada penghimpunan dana dan penyaluran dana. Akad pelengkap tersebut sebagai berikut :

\section{Wakalah}

18 Nawawi, Perbankan Syariah. 
Wakalah dapat disebut juga sebagai pendelegasian atau perwakilan yang merupakan pelimpahan kekuasan oleh suatu pihak (Muwakkil) kepada pihak atau orang lain (wakil) atas hal-hal yang diperbolehkan dalam islam diwakilkan. Dalam hal ini, wakil hanya melaksanakan suatu hal sebatas kuasa atas wewenang yang diberikan oleh muwakkil, apabila wakil telah melakukan wewenang tersebut sesuai dengan perjanjian maka semua risiko yang terjadi sepenuhnya menjadi tanggung jawab muwakkil atau pemberi kuasa. ${ }^{19}$

Syarat - syarat akad Wakalah, yaitu :

a. Obyek akad harus jelas dan dapat diwakilkan.

b. Akad, obyek maupun transaksinya tidak boleh bertentangan dengan syariat islam.

Rukun akad wakalah ialah :

a. Pelaku akad, yaitu pemberi kuasa (muwakkil) dan penerima kuasa (wakil).

b. Obyek akad, yaitu obyek yang dikuasakan (taukil)

${ }^{19}$ Sudarsono, Bank Dan Lembaga Kuangan Syariah. 
c. Shighat, yaitu ijab dan qabul.

Akad wakalah dalam praktik perbankan syariah sebagai berikut ${ }^{20}$ :

a. Wakalah dalam perbankan, apabila nasabah memberikan kuasa kepada pihak perbankan untuk mewakili untuk melakukan suatu jasa tertentu, seperti Letter of Credit (L/C), transfer, dan inkaso.

b. Diantara keduanya, bank dan nasabah harus cakap hukum. Pada pembukaan L/C, apabila dana nasabah tidak cukup maka penyelesaiannya dapat dilakukan dengan produk pembiayaan murabahah, salam, ijarah, musyarakah dan mudharabah.

c. Kegagalan yang disebabkan atas kelalaian menjalankan kuasa nasabah akan menjadi tanggung jawab pihak bank kecuali berupa force majeure menjadi tanggung jawab nasabah itu sendiri.

d. Tugas, wewenang dan tanggung jawab bank harus sesuai kehendak nasabah. Setiap bank melaksanakan

20 Ibid. 
tugas

tersebut

harus

mengatasnamakan nasabah. Bank akan mendapat fee atas tugas tersebut sesuai kesepakatan dan tidak boleh dibatalkan oleh satu pihak.

e. Akad awakalah ini akan berakhir apabila tugas atau wewenang telah dilaksanakan sesuai perjanjian anatara nasabah dengan bank.

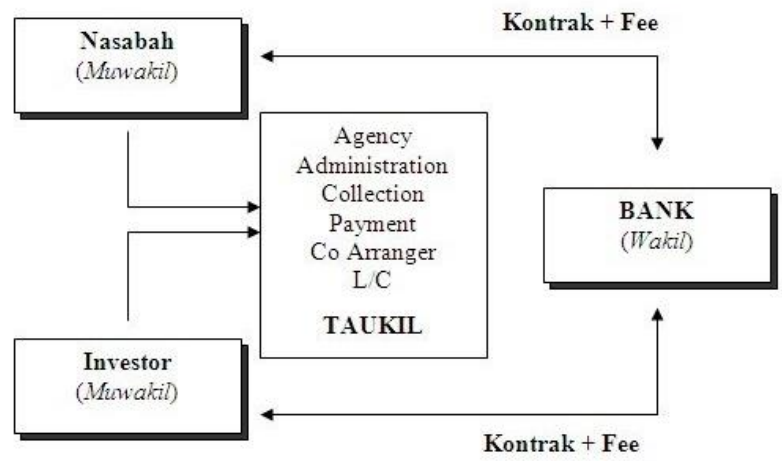

Gambar 3. Skema wakalah

2. Kafalah

Kafalah merupakan jaminan atau tanggungan yang diberikan oleh penanggung (kafil) kepada pihak ketiga untuk memenuhi kewajiban pihak kedua atau tertanggung. 
Akad wakalah dalam praktik perbankan syariah sebagai berikut ${ }^{21}$ :

a. Bank garansi diberikan untuk menjamin pembayaran atas kewajiban pembayaran. Bank dapat memberikan syarat kepada nsabah untuk menempatkan sejumlah dana sebagai fasilitas yaitu prinsip rahn.

b. Bank juga berhak menerima tersebut dengan prinsip wadiah. Bank mendapatkan pengganti biaya atas jasa tersebut.

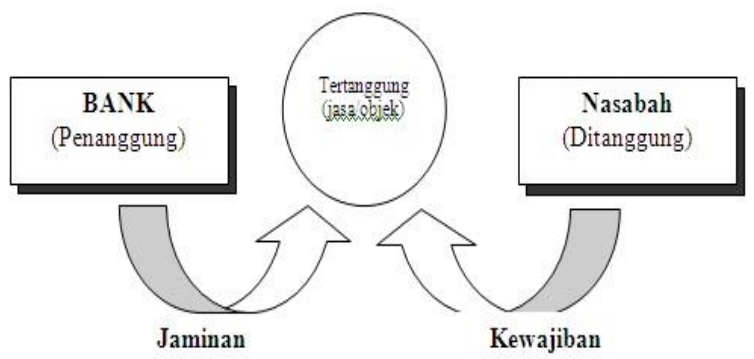

\section{Gambar 4. Skema Kafalah}

3. Hiwalah

Hiwalah diambil dari kata "tahwil" yang artinya perpindahan. Hiwalah adalah perpindahan (pengalihan)hutang dari orang

${ }^{21}$ Khaddafi et al., Akuntansi Syariah Meletakkan Nilai-Nilai Syariah Islam Dalam Ilmu Akuntansi. 
yang berhutang(muhil) kepada orang yang berkewajiban membayar hutang (muhal alaihi). Misalnya, si A mempunyai piutang pada si $B$, dan si A mempunyai hutang dengan jumlah sama kepada si $C$ tetapi si $A$ tidak mampu membayar hutang ke si $\mathrm{C}$ maka si $\mathrm{A}$ mengalihkan hutang tersebut kepada si $\mathrm{B}$. Selanjutnya, si B harus membayar kepada si $C$ dan si A tidak mempunyai hutang lagi kepada si $\mathrm{C}^{22}$.

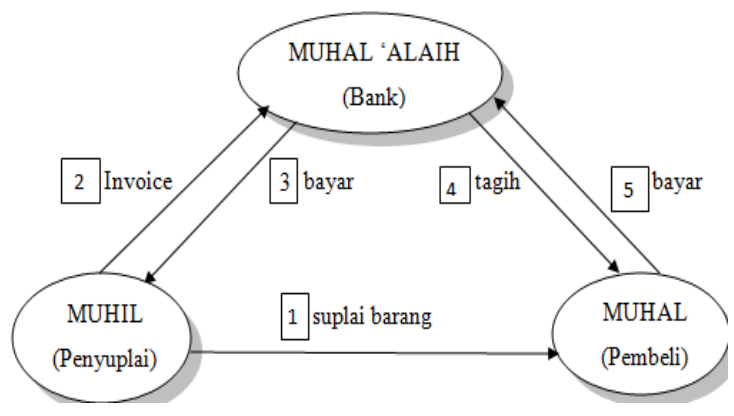

Gambar 5. Skema Hiwalah

Dalam praktek perbankan ${ }^{23}$ :

a. Fasilitas hiwalah biasanya untuk membantu supplier mendapatkan modal agar usahanya tetap berjalan. Bank juga mendapat pengganti

\footnotetext{
${ }^{22}$ Nawawi, Perbankan Syariah.

${ }^{23}$ Khaddafi et al., Akuntansi Syariah Meletakkan Nilai-Nilai Syariah Islam Dalam IImu Akuntansi.
} 
biayaa atas jasa pemindahan piutang tersebut.

b. Untuk mengantisipasi risiko kerugian, bank melakukan penelitian atas kemampuan pihak yang berhutang dsn kebenaran transaksi antara yang mengalihkan piutang dengan yang berhutang.

c. Ketika kebutuhan barang supplier akan likuiditas maka ia meminta ke pihak bank untuk mengambil alih piutang. Bank akan menerima pembayaran dari pemilik proyek.

\section{Rahn (Gadai)}

Rahn merupakan sesuatudengan memungkinkan dapat ditarik kembali. Secara teknis rahn merupakan menjadikan suatu harta yang bernilai sebagai jaminan hutang. Tujuan rahn itu sendiri adalah untuk memberikan jaminan pembayaran kembali pada pihak bank atau lembaga keuangan atas pembiayaan ${ }^{24}$.

Rukun rahn, yaitu :

a. Pelaku akad, yaitu rahin (pemilik barang) dan murtahin (pemegang barang).

${ }^{24}$ Wiroso, Produk Perbankan Syariah. 
b. Obyek akad, yaitu marhun (harta yang bernilai)

c. Sighat, yaitu ijab dan qabul

Teknis dalam perbankan sebagai berikut ${ }^{25}$ :

a. Nasabah dapat menggunakan harta yang dilimilki untuk digadaikan kepada pihak bank dengan tidak mengurangi nilai dang merusak harta tersebut.

b. Apabila terjadi wanprestasi pada nasabah, pihak bank boleh melakukan penjualan barang gadai tersebut atas perintah hakim.

c. Barang tersebut, nasabah juga boleh menjualnya sendiri dengan seizing bank. Jika nilai penjualan atas barang tersebut melebihi kewajibannya maka lebihnya menjadi hak milik nasabah. Dan sebaliknya, apabila hasil penjualan lebih kecil maka nasabah menutupi kekurangannya.

${ }^{25}$ Heri Sudarsono, Bank Dan Lembaga Kuangan Syariah. 


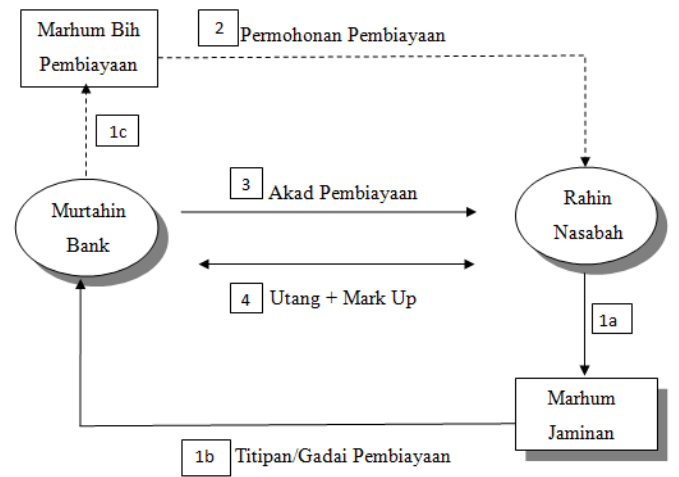

Gambar 6. Skema Rahn

\section{Qardh}

Al-Qardh merupakan memberikan pinjaman kepada nasabah dengan ketentuan nasabah wajib mengembalikan dana yang sesuai jumlah yang diterima saat akad dengan lembaga keuangan syariah tanpa biaya lainnya. Al-Qardh dikategorikan sebagai akad ta'awwun atau tolong menolong dan bukan transaksi komersial.

Praktek dalam dunia perbankan, Al-Qardh bianya dilakukakn dalm empah hal yaitu ${ }^{26}$ :

a. Qardh sebgai pinjman talangan haji, yang artinya nasabah calon haji diberikan talangan terlebih dahulu untuk syarat setor biaya haji. Nasabah

${ }^{26}$ Muhammad, Manajemen Perbankan Syariah (Yogyakarta: UPP AMP YKPN, 2005). 
tersebut melunasi talangan tersebut sebelum keberangkatan haji.

b. Pinjaman tunai (cash advanced)dari produk kartu kredit syariah. Nasabah duberi kebebasan untuk menarikuang tunai milik bank melalui ATM. Nasabah mengembalikan pinjaman itu sesuai waktu kesepakatan.

c. Pinjaman kepada pengusaha kecil. Apabila pengusaha kecil diberi pinjaman dengan skema jual-beli, ijara atau bagi hasil itu menurut pihak bank akan memberatkan pengusaha tersebut.

d. Pinjaman kepada pengurus bank. Bank menyediakan fasilitas tersebut untuk memastikan terpenuhinya kebutuhan para pengurus bank, dan mengembalikannya secara mencicil melalui pemotongan gaji mereka. 


\section{E. Rangkuman}

Menghimpun dana dari masyarakat yang dilakukan oleh bank syariah dapat dilakukan dengan menggunakan tabungan, deposito, dan giro yang secara keseluruhan disebut dengan dana syirkah temporer. Berdasarkan fatwa Dewan Syariah Nasional (DSN-MUI), prinsip penghimpunan dana dalam bank syariah ada dua, yaitu prinsip mudharabah dan prinsip wadiah.

Dalam bank syariah produk pembiayaan dapat dilakukan menggunakan skema jual beli, skema sewa, dan investasi. Jual beli ada beberapa macam yaitu murabahah, salam dan istihna'. Pada investasi terdiri atas dua macam, yaitu musyarakah dan mudharabah. Dan untuk skema ijarah (sewa) terdiri atas ijarah dan ijarah muntahiya bittamlik.

Dalam kedua transaksi diatas terdapat Produk akad pelengkap yang biasanya digunakan untuk melengkapi akad yang ada seperti akad wakalah digunakan untuk melengkapi akad murabahah dimana bank dapat mewakilkan kepada nasabah untuk membeli barang yang dibutuhkan dengan melampirkan surat wakalah dari bank.

\section{F. Studi Kasus}

1. Jelaskan perbedaan antara penghimpunan dana pada bank syariah dengan penghimpunan dana pada bank konvensional! 
2. Jelaskan perbedaan mekanisme transfer antar kantor bank yang sama dengan antar bank yang berbeda!

3. Akad apakah yang biasa digunakan untuk giro di bank syariah di Indonesia? Jelaskan kelebihan dan kekurangannya!

4. Akad apakah yang biasa digunakan untuk tabungan di Indonesia? Jelaskan kelebihan dan kekurangannya! 


\section{BAB III}

\section{TEORI DAN PRAKTEK AKUNTANSI TRANSAKSI MURABAHAH}

\section{Kompetensi Dasar}

Setelah mempelajari bab ini, diharapkan membentuk mahasiswa yang kompeten dalam hal berikut :

1. Mampu melakukan pencatatan transaksi akuntansi dengan akad murabahah.

2. Pemahaman terhadap pengakuan dan pengukuran, penyajian serta pengungkapan akuntansi murabahah.

\section{Indikator}

Indikator yang ada dalam bab ini, sebagai berikut :

1. Kemampuan proses akuntansi untuk transaksi akad murabahah

\section{Materi Pokok}

Materi utama pada bab ini adalah Akuntansi penyaluran dana dengan akad murabahah.

\section{A. Definisi Murabahah}

Al-Murabahah sendiri berasal dari kata al-ribh yang merupakan secara bahasa berarti al-ziyadah \{tambahan\} dan al-nama \{tumbuh dan berkembang\} 
dalam suatu perniagaan \{al-tijarah\}. ${ }^{27}$ Secara harfiah arti dari Al-Murabahah sama dengan arti dari al-riba yang secara harfiah pun yang berarti tumbuh, bertambah, dan berkembang.

Jual beli Al-Murabahah yaitu Penjual dan pembeli melakukan sebuah transaksi jual beli mengenai suatu objek tertentu yang harganya jauh lebih tinggi dari harga pada perolehan. Sedangkan Ibnu Qudamah mengemukakan bahwasannya murabahah sebagai jual beli dengan menghitung modal ditambah keuntungan tertentu yang diketahui. ${ }^{28}$ Wahbah alZuhaili telah menegaskan bahwasannya jual beli murabahah adalah; ${ }^{29}$

"Jual-beli dengan harga perolehan disertai tambahan sebagai keuntungan"

Jual beli Murabahah sendiri merupakan suatu akad yang cukup populer di kalangan para pelaku usaha perbankan syariah, karena dihubungkan dengan suatu praktek bisnis yang bertautan, akad murabahah yang dasarnya merupakan suatu bagian dari akad amanah

\footnotetext{
${ }^{27}$ Fayadh 'Abd al-Mun'im al-Hasanain, Bai' al-murabahah fi alMasharif al-Islamiyyah (Kairo: al-Ma' had al-'Alami li al-Fikr alIslami. 1996), hlm.19.

${ }^{28}$ Fuad Sarthawy, at-Tamwīl al-Islämī wa Daur al-Qithā' alKhāsh, cet.1, (Jordan: Dār al-Masīra,tt), hlm. 235

${ }^{29}$ Wahbah al-Zuhaili, al-Fiqh al-Isami wa Adillatuhu (Damaskus: Dar al-Fikr 2006), Vol. V, hlm. 3.766
} 
yang merupakan suatu topik akad yang sangat banyak didiskusikan di berbagai lapisan. Di antara cirinya yaitu banyaknya fatwa DSN-MUI yang terkait Jual-Beli Murabahah.

\section{B. Rukun Pembiayaan Murabahah}

Sebagai salah satu dari jual beli, maka dari itu pada dasarnya rukun jual beli murabahah sama juga dengan rukun jual beli pada umumnya. Adapun rukun jual beli murabahah adalah: ${ }^{30}$

1. Penjual (Ba'i)

Yaitu pihak yang telah membiayai pembelian suatu barang yang diperlukan para nasabah pemohon pembiayaan dengan menggunakan sistem pembayaran yang ditangguhkan. Pada umumnya dalam teknis aplikasinya bank membeli barang sesuai kebutuhan nasabah atas nama bank.

2. Pembeli (Musytari)

Pembeli yang berada dalam pembiayaan murabahah adalah nasabah yang mengajukan permohonan pembiayaan ke bank atau BMT tersebut.

3. Objek jual beli (Mabi'i)

Dalam pembiayaan murabahah yang sering dilakukan oleh nasabah untuk permohonan

${ }^{30}$ Muhammad, Model-Model Akad Pembiayaan di Bank Syariah (Panduan teknis pembuatan Akad/Perjanjian Pembiayaan Pada Bank Syariah), Yogyakarta: UII Press, 2009, hlm.58 
pembiayaan adalah barang-barang yang sifatnya konsumtif untuk pemenuhan kegiatan kebutuhan produksi, seperti rumah, mobil, motor, rumah dan lainnya.

4. Harga (Tsaman)

Harga yang ada di dalam pembiayaan murabahah diibaratkan dengan pricing atau plafond pembiayaan

5. Ijab Qabul

Dalam suatu perbankan syariah atau lembaga keuangan lainnya yang dimana operasionalnya mengacu pada hukum islam, maka akad yang dilaksanakan juga memiliki konsekuensi dalam hal duniawi dan akhirat. Di dalam akad memuat tentang spesifikasi barang, kesediaan pihak bank syariah dalm pengadaan barang, dan juga pihak bank syariah harus memberitahukan harga pokok dan keuntungan pada nasabah, lalu lama angsuran apabila terjadi kesepakatan murabahah.

\section{Skema Pembiayaan Murabahah}

Dalam pembiayaan murabahah, terdapat adanya dua pihak yang melakukan transaksi jual beli, yaitu 
bank syariah sebagai penjual dan nasabah sebagai pembeli barang. ${ }^{31}$

Skema Akad Murabahah ${ }^{32}$

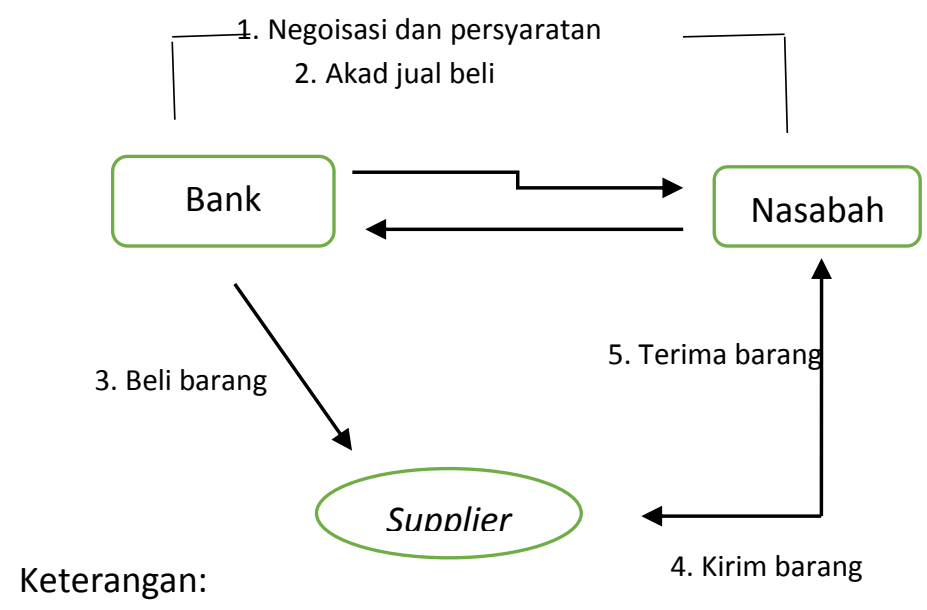

1. Nasabah dan Bank Syariah melaksanakan negoisasi mengenai rencana transaksi jual beli yang akan dilakukan. Poin inti dari negosiasi tersebut meliputi jenis barang yang akan dibeli, harga jualnya dan kualitas barang tersebut.

2. Selanjutnya bank syariah akan mempelajari kemampuan si nasabah dalam hal membayar

${ }^{31}$ Dra.Ismail,MBA,AK,Perbankan Syariah Edisi Pertama,h.139

32 Dra.Ismail,MBA,AK,Perbankan Syariah Edisi Pertama,h.139140 
piutang murabahah. Jikalau rencana pembelian barang berhasil dan disepakati oleh kedua belah pihak maka bank syariah akan memesan barang tersebut ke supplier.

3. Bank syariah akan melakukan akad jual beli dengan nasabah, yang dimana penjualnya yaitu bank syariah dan pembelinya si nasabah. Di dalam akad tersebut, ditetapkannya barang yang menjadi objek jual beli yang telah dipilih oleh nasabah dan harga jual barang tersebut.

4. Dengan dasar akad yang dilakukan bank syariah dan nasabah, maka bank akan membelikan barang ke supplier. Pembelian yang dilaksanakan oleh bank sesuai dengan keinginan nasabah.

5. Supplier mengirimkan barang pesanan ke nasabah dengan atas perintah bank syariah

6. Nasabah menerima barang dan menerima dokumen kepemilikan barang

7. Setelah menerimanya, nasabah melakukan pembayaran. Pembayaran yang dilakukan nasabah biasanya dilakukan dengan cara angsuran.

\section{Cakupan Akuntansi Pembiayaan Murabahah}

Standar akuntansi murabahah berdasar pada metode pengakuan pendapatan murabahah. Menurut PAPSI 2013, dalam pengakuan murabahah 
yang memakai metode anuitas wajib menggunakan PSAK 55 (2011) tentang Instrumen Keuangan: Pengakuan dan Pengukuran, PSAK 50 (2010) tentang Instrumen Keuangan: Penyajian, PSAK 60: Instrumen Keuangan: Pengungkapan dan PSAK lain yang sesuai, selama itu tidak bertentangan dengan prinsip Syariah. Hal ini karena metode anuitas harus sesuai pada asumsi pembiayaan (financing). Apabila bank memilih menggunakan metode proporsional maka pencatatan transaksi Murabahah menggunakan PSAK 102 tentang Akuntansi Murabahah. ${ }^{33}$

Standar ini mulai berlaku dengan efektif sejak 1 Januari 2008.. PSAK ini menggantikan PSAK 59 yang berhubungan dengan pengakuan, pengukuran, penyajian, dan pengungkapan murabahah. PSAK 102 dapat diterapkan untuk lembaga keuangan syariah seperti bank, asuransi, lembaga pembiayaan, dana pensiun, koperasi, dan lainnya yang menjalankan transaksi murabahah. Di samping itu, PSAK 102 juga diterapkan oleh semua pihak yang melakukan transaksi murabahah dengan LKS tersebut (PSAK 102 paragraf 2 dan 3).

PSAK 102 juga memberikan panduan bagi pembeli akhir. Beberapa hal yang secara khusus diatur dalam standar ini antara lain adalah utang yang timbul dari

\footnotetext{
${ }^{33}$ PSAK 102,Pedoman Standar Akuntansi Perbankan Syariah, (Jakarta : Ikatan Akuntansi Indonesia.2007)
} 
transaksi, aset yang diperoleh, beban murabahah, diskon pembelian yang diterima dari penjual, denda yang dibayar akibat kelalaian, dan potongan uang muka akibat pembatalan pembelian.

\section{E. Akun Transaksi Pembiayaan Murabahah}

1. Akun sebagai pihak penjual dalam transaksi Murabahah.

a. Akun-akun pada laporan posisi keuangan (Neraca)

1) Persediaan / asset Murabahah

Digunakan mencatat asset yang yang dimiliki oleh LKS atau penjual untuk melakukan transaksi murabahah. Akun ini disisi debet ketika perolehan asset untuk dijual, seluruh biaya agar asset tersebut memiliki nilai ekonomis seperti biaya kelengkapan surat. Dan disisi kredit ketika asset atau aktiva tersebut terjual.

2) Piutang murabahah

Untuk mencatat harga jual yang telah disetujui bersama dalam akad murabahah tetapi belum terbayar oleh 
pembeli. Akun ini berada disisi debet ketika terjadi transaksi jual beli murabahah dimana pembayarannya secara tangguh sebesar harga jual. Sedangkan disisi kredit ketika pembayaran harga barang secara angsuran maupun keseluruhan dan ketika uang muka yang telah dibayar oleh nasabah dikurangi.

3) Margin murabahah tangguhan

Digunakan untuk mencatat keuntungan yang diperoleh dari transaski murabahah dan belum dibayar oleh pembeli. Akun ini sebagai pengurang dari piutang murabahah. Berada disisi kredit ketika akad murabahah terjadi dan pembayarannya secara cicilan.

4) Hutang diskon murabahah (kewajiban ke pembeli)

Untuk mencatat diskon yang diperoleh dari pemasok yang telah tercantum dan 
diperjanjikan dalam akad yang merupakan hak pembeli. Akun ini adalah penambah pendapatan margin murabahah milik LKS sebagai pengelola dan pemilik dana. Berada disisi kredit apabila diterimanya diskon dari pemasok sedangkan disisi debet ketika pembayaran kewajiban.

5) Piutang uang muka murabahah

Digunakan untuk mencatat uang muka yang diberikan oleh LKS kepada pemasok. Akun ini disisi debet ketika membayarkan uang muka kepada pemasok. Dan disisi kredit ketika pelunasan kepada pemasok sebesar uang muka yang telah dibayar.

6) Hutang uang muka murabahah

Untuk mencatat penerimaan uang muka lembaga dari pembeli. Akun ini disisi debet ketika (1)akad murabahah 
dilaksanakan

sebagai

pengurang

piutang

murabahah (2) pengembalian

uang muka setelah dikurangi

dengan kerugian. Sedangkan

disisi kredit ketika menerima uang muka dari pembeli.

7) Cadangan

kerugian murabahah

Digunakan

mencatat

cadangan atau penyisihan dana atas kemungkinan terjadinya kerugian dengan tidak tertagihnya piutang murabahah dan kerugian lain atas transaksi murabahah lainnya oleh LKS. Akun ini berada disisi debet ketika dilakukan penghapusan piutang murabahah dan dikredit ketika dilakukannya penyisihan dana untuk kemungkinan kerugian terjadi.

8) Piutang pada nasabah Untuk mencatat kerugian lembaga dimana kerugian lebih besar dari uang muka dari pembeli. Dan kerugian 
atas pembatalan suatu transaksi murabahah.

b. Akun-akun Laba Rugi

1) Pendapatan

margin murabahah

Pencatatan atas margin yang didapat dari transaksi murabahah, baik yang sudah di bayar maupun yang masih dalam pengakuan. Akun ini berada disisi debet ketika (1)pemberhentian

pengakuan pendapatan (akrual). (2) dipindahkan ke pendapatan operasional atau usaha utama. Dan berada disisi kredit ketika (1) diterimanya pembayaran sebesar porsi margin. (2) pengakuan atas angsuran murabahah.

2) Potongan

pelunasan murabahah

Untuk mencatat pemberian potongan angsuran atas permintaan nasabah saat pelunasan lebih awal. Akun ini termasuk pengurang akun pendapatan margin 
murabahah LKS. Berada disisi debet ketika pemberian potongan sebesar potongan yang diberikan sedangkan disisi kredit ketika dipindahkan ke pendapatan operasional atau usaha utama.

3) Potongan angsuran murabahah - prestasi

Untuk mencatat potongan angsuran yang diberikan LKS kepada pembeli akibat prestasi kemampuan bayar angsuran pembeli yang tepat waktu. Akun ini termasuk pengurang pendapatan margin LKS. Berada disisi debet ketika pemberian potongan harga angsuran sedangkan disisi kredit ketika dipindahkan ke pendapatan operasional atau usaha utama.

4) Potongan angsuran murabahah - beban operasi Pencatatan atas potongan angsuran oleh LKS kepada pembeli akibat penurunan 
kemampuan bayar pembeli. Akun ini termasuk beban LKS. Berada disisi debet ketika pemberian potongan harga angsuran sedangkan disisi kredit ketika dipindahkan ke laporan laba rugi akhir tahun.

5) Diskon murabahah

Digunakan untuk mencatat diskon yang diperoleh dari pemasok yang telah tercantum dan diperjanjikan dalam akad Akun ini adalah penambah pendapatan margin murabahah milik LKS sebagai pengelola dan pemilik dana. Berada disisi kredit apabila diterimanya diskon yang menjadi hak LKS sedangkan disisi debet ketika dipindahkan ke laporan laba rugi akhir tahun.

6) Beban kerugian murabahah Digunakan untuk mencatat beban kerugian yang dialami oleh penjual atas transaksi murabahah akibat kemungkinan tidak tertagihnya piutang 
murabahah dan pengadaan barang oleh lembaga keuangan syariah sebagai penjual. Akun ini berada disisi debet ketika penyisihan kerugian sedangkan disisi kredit ketika dipindahkan ke akun laba rugi.

7) Kerugian penurunan asset murabahah

Digunakan untuk mencatat kerugian asset murabahahyang dimiliki oleh LKS sebagai penjual sebelum diserahkan kepada pembeli akhir. Berada disisi debet apabila nilai bersih asset murabahah lebih kecil dari nilai perolehan sedangkan disisi kredit ketika dipindahkan kea kun laba rugi pada akhir tahun. 
2. Akun sebagai pihak pembeli dalam transaksi Murabahah.

a. Akun-akun pada laporan posisi keuangan (Neraca)

1) Kewajiban murabahah

Untuk mencatat harga beli yang telah di sepakati oleh kedua pihak dimana pembayarannya dilakukan secara cicilan atau secara tangguh.

Akun ini berada disisi debet saat melakukan pembayaran harga kepada penjual dan disisi kredit ketika akad murabahah dilaksanakan.

2) Piutang uang muka murabahah

Digunakan untuk mencatat pembayaran uang muka kepada lembaga keuangan syariah sebagai tanda keseriusan atas transaksi murabahah. Akun ini disisi debet ketika pembayaran uang muka sedangkan disisi kredit ketika berlangsungnya murabahah, sebagai 


\section{pengurang hutang kepada}

penjual. 


\section{3) Aktiva tetap}

Digunakan dalam pencatatan atas barang yang didapat dari transaksi murabahah. Akun ini disisi debet ketika diperoleh barang sebesar harga perolehan dan disisi kredit ketika barang tersebut dijual.

4) Hutang kepada LKS

Pencatatan atas angsuran yang jatuh tempo tetapi belum dibayarkan oleh pembeli. Berada disisi debet pada saat dilakukan pembayaran, sedangkan disisi kredit saat jatuh tempo angsuran tetapi belum dibayar.

b. Akun-akun Laba Rugi

1) Beban murabahah ditangguhkan

Untuk mencatat laba yang di sepakati dengan pembayaran secara cicilan. Akun ini disajikan sebagai pengurang hutang murabahah. Berada disisi kredit ketika akad murabahah terjadi sebesar 
keuntungan yang telah disepakati sedangkan disisi debet ketika pembayaran angsuran atau pelunasan sebesar keuntungan tersebut.

2) Diskon murabahah

Digunakan untuk mencatat diskon yang diperoleh dari pemasok. Akun ini adalah pengurang beban murabahah. Berada disisi kredit apabila diterimanya diskon sedangkan disisi debet ketika dipindahkan ke laporan laba rugi akhir tahun.

3) Potongan pelunasan kewajiban murabahah

Digunakan untuk mencatat potongan harga yang diterima dari LKS atas pelunasan kewajiban yang dilakukan sebelum jatuh tempo. Akun ini tidak diakui sebagai pendapatan tetapi sebagai pengurang beban murabahah atas transaksi murabahah. 
4) Kerugian

pesanan murabahah

Digunakan untuk mencatat kerugian yang timbul akibat batalnya transaksi murabahah. Berada disisi debet ketika terjadi kerugian dan disisi kredit ketika tutup buku akhir tahun yang di pindahkan ke akun laba rugi.

\section{5) Beban denda murabahah}

Untuk mencatat beban denda yang dikenakan penjual kepada pembeli. Akun ini berada disisi debet ketika denda dikenakan dan disisi kredit ketika tutup buku akhir tahun yang dipindahkan ke akun laba rugi.

\section{F. Rangkuman}

Murabahah ialah transaksi jual beli dengan menyatakan harga perolehan dan keuntungan yang disepakati kedua belah pihak dengan pembayaran secara tunai atau tangguh. 
Dalam PAPSI 2013 telah diatur akun terkait pembiayaan murabahah untuk disajikan dalam laporan keuangan :

1. Uang muka murabahah dari pembeli yaitu sebagai liabilitas.

2. Tagihan kepada nasabah atas pembatalan transaksi murabahah di mana uang muka nasabah lebih kecil dari beban riil yang dikeluarkan nasabah.

3. Piutang murabahah disajikan sebesar saldo pembiayaan murabahah nasabah kepada penjual.

4. Margin murabahah ditangguhkan disajikan sebagai pos lawan piutang murabahah.

5. Beban potongan pelunasan / angsuran murabahah sebagai pos lawan pendapatan margin

6. Dalam hal bank menggunakan metode proporsional, pendapatan dan beban terkait langsung dengan transaksi murabahah yang belum diamortisasi disajikan sebagai liabilitas lainnya dan aset lainnya.

7. Pendapatan margin murabahah yang akan diterima disajikan sebagai bagian dari aset.

8. Cadangan kerugian penurunan murabahah disajikan sebagai lawan piutang murabahah.

9. Denda (ta'zir) disajikan sebagai komponen dari sumber dana kebajikan.

\section{G. Studi Kasus Transaksi Pembiayaan Murabahah}

Soal-soal latihan:
A. Soal Teori 
1. Jelaskanlah definisi murabahah!

2. Untuk transaksi apa sajakah, murabahah cocok digunakan?

3. Sebutkanlah landasan syar'i transaksi murabahah?

4. Jelaskanlah rukun transaksi murabahah!

5. Bolehkah bank syariah mengenakan denda terhadap nasabah mampu tapi yang menundanunda pembayaran dengan sengaja? Bagaimanakah perlakuan akuntansi terhadap denda yang dikenakan? 


\section{B. Soal Kasus}

\section{Kasus 1}

Pada tanggal 1 Maret 20XA PT. Kemal Sejahtera melakukan negosiasi dengan BPRS Ridho Ilahi untuk memperoleh fasilitas murabahah dengan pesanan untuk 1set server seharga Rp 80.000.000 dengan rencana sebagai berikut:

\begin{tabular}{|l|c|}
\hline $\begin{array}{l}\text { Harga Total } \\
\text { Barang }\end{array}$ & Rp 80.000.000,00 \\
\hline Uang muka & Rp 20.000.000,00 \\
\hline $\begin{array}{l}\text { Pembiayaan } \\
\text { oleh BPRS }\end{array}$ & Rp $7.375 .570,25$ \\
\hline $\begin{array}{l}\text { Margin } \\
\text { Harga jual }\end{array}$ & Rp 87.375.570,25 (harga \\
& barang plus margin) \\
\hline $\begin{array}{l}\text { Jumlah bulan } \\
\text { angsuran }\end{array}$ & $0,5 \%$ dari pembiayaan oleh \\
\hline $\begin{array}{l}\text { Biaya } \\
\text { administrasi }\end{array}$ & BPRS \\
\hline
\end{tabular}


Diminta :

1. Hitunglah angsuran per bulan yang mesti dibayar oleh PT. Kemal Sejahtera.

2. Hitunglah persentase keuntungan dari total piutang.

3. Hitunglah besar margin dan pokok piutang dalam setiap angsuran perbulan yang dibayar oleh PT. Kemal Sejahtera jika menggunakan metode proporsional.

\section{Kasus 2}

Dengan menggunakan data pada kasus 3, buatlah jurnal untuk transaksi berikut:

a. Tanggal 3 Maret 20XA, PT. Kemal Sejahtera menyerahkan uang muka sebesar Rp 20.000.000 kepada BPRS

b. tanggal 8 Maret 20XA, Untuk keperluan transaksi murabahah dengan PT. Kemal Sejahtera, BPRS melakukan pembelian barang pesanan PT. Kemal Sejahtera kepada pemasok senilai Rp 80.000.000 secara tunai. Jurnal untuk mencatat transaksi tersebut adalah sebagai berikut:

c. Tanggal 10 Maret, akad jual beli murabahah disepakati antara Bank dan PT. Kemal Sejahtera Pada saat itu Bank langsung menyerahkan satu set server kepada PT. Kemal Sejahtera. 
d. Pada tanggal akad, uang muka yang sebelumnya sudah diterima oleh BPRS diakui sebagai pengurang piutang murabahah.

e. Pada tanggal akad, nasabah dikenakan biaya administrasi sebesar 0,5\% dari pembiayaan oleh BPRS

f. Tanggal 10 April 20XA, saat jatuh tempo angsuran pertama nasabah membayar sebesar Rp 3,743,087.24

g. Pada pembayaran bulan Mei, hingga tanggal jatuh tempo angsuran kedua, BPRS belum menerima pembayaran angsuran dari PT. Kemal Sejahtera. Pembayaran angsuran baru dilakukan oleh nasabah pada tanggal 20 Mei, sebesar Rp3,743,087.24 melalui debet rekening.

h. Tanggal 10 Juni (tanggal jatuh tempo angsuran ketiga), ketika BPRS hendak mendebit rekening nasabah, didapati tidak terdapat dana yang cukup di rekening PT. Kemal Sejahtera untuk membayar angsuran bulan April. Saldo rekening yang tersedia hanya $\mathrm{Rp} 1.025 .000$ dan BPRS mendebit rekening sebesar Rp 1.000.000.

i. tanggal 15 Juni, PT. Kemal Sejahtera membayar kekurangan pembayaran angsurannya sebesar 2,743,087.24.

j. Hingga tanggal 10 Juli PT. Kemal Sejahtera tidak memenuhi kewajiban pembayaran angsurannya untuk bukan Juni. 
k. PT. Kemal Sejahtera baru membayar kewajibannya pada tanggal 5 Agustus 20XA. Karena ketidakdisiplinan PT. Kemal Sejahtera tersebut, BPRS mengenakan denda sebagaimana yang telah disepakati dalam akad yaitu sebesar $10 \%$ dari total pendapatan margin akrual yang tertunggak. PT. Kemal Sejahtera mengakui ketidakdisiplinannya dan bersedia membayarnya. Semua pembayaran dilakukan pada tanggal 5 Agustus 20XA

I. Tanggal 10 Agustus 20XA, PT. Kemal Sejahtera bermaksud melunasi sisa kewajibannya dengan nilai buku Rp 52.403.221,30 yang terdiri atas pokok pembiayaan sebesar $\mathrm{Rp}$ 46.666.666,66 dan margin yang ditangguhkan sebesar Rp 5.736.554,64 Disepakati pada saat pelunasan bahwa potongan pelunasan akan diberikan sebesar $80 \%$ dari sisa margin murabahah yang masih ditangguhkan.

\section{Kasus 3}

Pada tanggal 3 Maret 20XA PT. Agifira melakukan negosiasi dengan BPRS Arta Makmur untuk memperoleh fasilitas Murabahah dengan pesanan untuk 5 unit Laptop @ Rp 10.000.000 dengan rencana sebagai berikut:

Diminta : 


\begin{tabular}{|l|l|}
\hline $\begin{array}{l}\text { Harga Total } \\
\text { Barang }\end{array}$ & Rp 50.000.000,00 \\
\hline $\begin{array}{l}\text { Pemg muka } \\
\text { BPRS }\end{array}$ & $\begin{array}{l}\text { Rp 10.000.000,00 (sama dengan 20\% } \\
\text { dari harga barang) }\end{array}$ \\
\hline Margin & Rp 40.000.000,00 \\
& $\begin{array}{l}\text { Rp 1.257.763,74 (sama dengan dengan } \\
\text { 3.14440934\% margin flat tanpa } \\
\text { disetahunkan atau 9.43322802\% margin } \\
\text { flat disetahunkan atau 15\% margin } \\
\text { annuitas dari pembiayaan oleh BPRS) }\end{array}$ \\
\hline $\begin{array}{l}\text { Harga jual } \\
\text { Rp 51.257.763,74 (harga barang plus } \\
\text { administrasi }\end{array}$ & margin) \\
\hline $\begin{array}{l}\text { Jumlah bulan } \\
\text { angsuran }\end{array}$ & \begin{tabular}{l} 
4 Bulan \\
\hline
\end{tabular} \\
\hline
\end{tabular}

1. Hitunglah angsuran per bulan yang mesti dibayar oleh PT. Agifira.

2. Hitunglah persentase keuntungan dari total piutang.

3. Hitunglah besar margin dan pokok piutang dalam setiap angsuran yang dibayar oleh PT. Agifira jika menggunakan metode proporsional. 
4. Hitunglah besar margin dan pokok piutang dalam setiap angsuran yang dibayar oleh PT. Agifira selama periode berjalan dengan menggunakan metode annuitas.

\section{BAB IV \\ TEORI DAN PRAKTEK AKUNTANSI TRANSAKSI SALAM}

\section{Kompetensi Dasar}

Setelah mempelajari bab ini, diharapkan membentuk mahasiswa yang kompeten dalam hal berikut :

1. Mampu melakukan pencatatan transaksi akuntansi dengan akad salam dan salam paralel

2. Pemahaman terhadap pengakuan dan pengukuran, pengungkapan serta penyajian akuntansi salam dan salam paralel.

\section{Indikator}

Indikator yang ada dalam bab ini, sebagai berikut :

1. Kemampuan proses akuntansi untuk transaksi akad salam dan salam paralel

\section{Materi Pokok}

Materi utama pada bab ini adalah Akuntansi penyaluran dana dengan akad salam dan salam paralel. 


\section{A. Definisi Salam}

Salam merupakan akad jual beli berupa barang pesanan (muslam fiih) dengan penangguhan pengiriman oleh penjual (muslam ilaihi) dan harganya dibayar diawal pada saat akad disepakati sesuai syarat-syarat tertentu. ${ }^{34}$ Pada praktek perbankan, bank dapat bertindak sebagai pembeli atau penjual pada transakasi salam. Apabila bank sebagai penjual kemudian memesan barang kepada agen untuk menyediakan barang pesanan dengan akad salam maka disebut salam paralel.

\section{B. Rukun Pembiayaan Salam}

Terdapat lima rukun pada akad salam, yaitu ${ }^{35}$ :

1. Muslam, yaitu pembeli atau pemesan barang.

2. Muslam ilaihi, yaitu penjual atau yang menyediakan barang (pemasok).

3. Muslam fiihi, obyek atau barang yang dipesan.

Ketentuan mengenai barang yang dipesan (muslam fiih), yaitu ${ }^{36}$ :

\footnotetext{
${ }^{34}$ PSAK 103,Pedoman Standar Akuntansi Perbankan Syariah, (Jakarta : Ikatan Akuntansi Indonesia.2007)

${ }^{35}$ Osmad Muthaher, Akuntansi Perbankan Syariah (Yogyakarta: Graha Ilmu, 2012).

${ }^{36}$ Mubarok, Jaih, Hasanudin, Fikih Mu'amaliyah Maliyyah Akad Jual Beli, ed. Iqbal Triadi Nugraha (Bandung: Simbiosa Rekatama Media, 2017).
} 
a. Harus diketahui jenis dan tipe (spesifikasi barang harus jelas)

b. Terhindar dari unsur Riba.barang pesanan harus berupa barang yang ada bandingannya di masyarakat atau ada harga pasar (nilai wajar).

c. Harus di tentukan mengenai tempat serah terima apabila barang sudah ada.

4. Modal atau uang.

5. Sighat akad, yaitu ijab dan Kabul.

Hasan Ayyub, dalam kitab Fiqh al- Mu'amaala alMaliya, menyatakan mengenai jual beli salam yang sah apabila telah terpenuhi enam syarat, yaitu ${ }^{37}$ :

1. Barang pesanan harus berupa benda yang dapat dideskripsikan.

2. Deskripsi barang tersebut harus memperjelas mengenai jenis, macam, dan sifat barang itu.

3. Ukuran barang yang dipesan harus diketahui, baik diukur dengan timbangan, takaran maupun alat ukur lainnya.

4. Jangka waktu pembuatan barang harus jelas.

5. Jangka waktu yang disepakati harus jangka waktu yang wajar untuk serah terima barang.

${ }^{37}$ Hasan Ayyub, Figh Al-Mu'amaalat Al-Maliyyah Fi Al-Islam (Kairo: Dar al-Salam, 2003). 
6. Harga atau pembayaran nilai barang harus dilaksanakan saat akad terjadi secara tunai kepada penerima.

\section{Skema Pembiayaan Salam}

\section{Pembiayaan Salam}

Pada pembiayaan salam, bank dapat menjadi penjual dan pembeli. Apabila bank menjadi penjual, bank dapat mengadakan barang secara sendiri dan juga dapat memesan kepada pihak industri (pembuat) atau petani. $^{38}$

Alur transaksi pembiayaan salam sebagai berikut :

1. Muslam (pembeli) bertransaksi dengan penjual untuk membeli kebutuhannya dengan memberikan spesifikasi barang yang akan dibeli.

2. Dalam transaksi pertama tersebut terjadi negoisasi anatara Muslam Ilaihi (penjual) dengan Muslam, dan ketika sepakat terjadilah akad salam.

3. Pada saat akad telah sah pembeli harus menyerahkan harga atas barang pesanan tersebut secara tunai.

4. Setelah terjadi akad salam dan pembayaran maka pihak penjual akan

38 Ibid.. 
melakukan produksi sesuai spesifikasi barang pesanan.

5. Barang pesanan dikirim secara tangguh (kemudian).

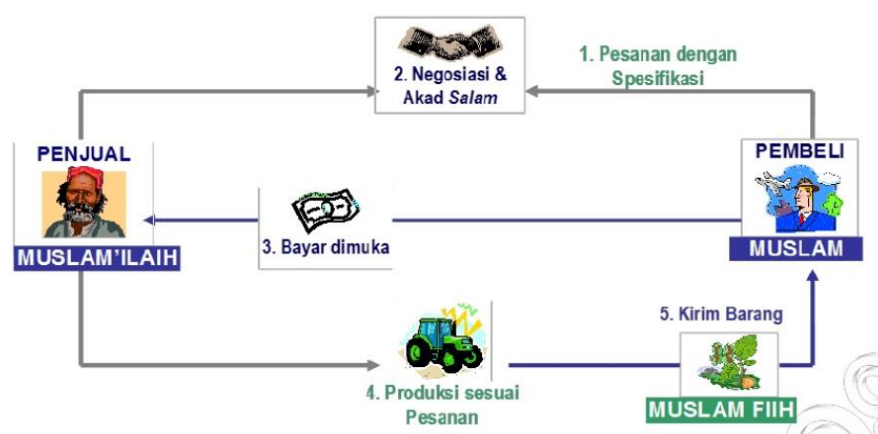

Gambar 7. Skema Akad Salam

\section{Pembiayaan Salam Paralel}

Salam Paralel dilakukan ketika bank bertindak sebagai penjual yang memenuhi barang pesanan dengan membeli kepada pihak lain (petani) sesuai spesifikasi barang yang sudah ada dengan akad salam. ${ }^{39}$

Syarat diperbolehkannya melakukan transaksi Salam Paralel, yaitu :

a. Akad kedua antara bank dengan pembuat (petani) tidak boleh terikat atau harus

${ }^{39}$ Wiroso, Akuntansi Transaksi Syariah (Jakarta: Ikatan Akuntan Indonesia, 2011). 
terpisah dari akad pertama.antara bank dengan pembeli akhir.

b. Akad kedua dilaksanakan apabila akad pertama telah sah.

Alur transaksi pembiayaan salam sebagai berikut :

1. Muslam (pembeli akhir) bertransaksi dengan penjual (bank) untuk membeli kebutuhannya dengan memberikan spesifikasi barang yang akan dibeli.

2. Dalam transaksi pertama tersebut terjadi negoisasi anatara Muslam Ilaihi (penjual) dengan Muslam, dan ketika sepakat terjadilah akad salam.

3. Pada saat akad telah sah pembeli harus menyerahkan harga atas barang pesanan tersebut secara tunai.

4. Setelah terjadi akad salam dan pembayaran, pihak bank menyediakan barang dengan memesan kepada pembuat atau petani sesuai jenis barang.

5. Barang pesanan dikirim secara tangguh (kemudian) sesuai dalam akad dan bank akan menerima dari pembuat kemudian dikirim kembali kepada pembeli akhir. 


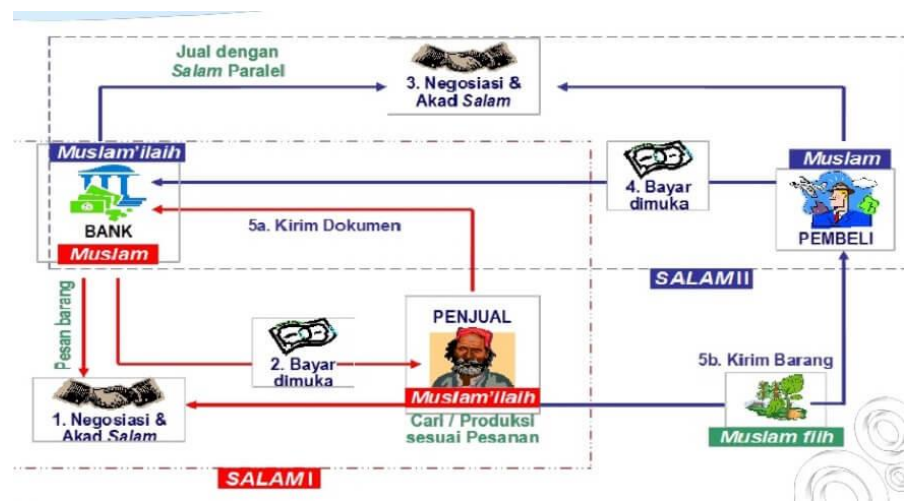

Gambar 8. Skema Salam Paralel

\section{Cakupan Akuntansi Pembiayaan Salam}

Dalam PSAK no.103 tentang akad musyarakah yang dimana pada paragraf 2 s.d 4 menjelaskan mengenai cakupan akuntansi salam dan akun yang diatur dalam $\mathrm{PSAK}^{40}$, yaitu :

2. Pernyataan ini diperuntukkan kepada :

(a) Lembaga keuangan syariah (LKS) yang melakukan transaksi salam baik sebagai pembeli atau penjual.

(b) semua pihak yang terkait dalam transaksi salam dengan LKS.

3. Pernyataan ini tidak mencakup aturan perlakuan akuntansi pada obligasi syariah (sukuk) yang memakai akad salam.

${ }^{40}$ PSAK 103,Pedoman Standar Akuntansi Perbankan Syariah, (Jakarta : Ikatan Akuntansi Indonesia.2007) 
4. Lembaga keuangan syariah tersebut:

(a) Perbankan syariah yang ada pada perundang-undangan yang berlaku,

(b) Lembaga keuangan syariah non-bank seperti lembaga pembiayaan syariah, dana pensiun syariah serta asuransi syariah.

(c) Lembaga keuangan syariah lainnya yang telah mendapat izin dari Negara melalui undang-undang yang berlaku untuk dapat menggunakan transaksi salam.

Dalam PSAK no. 103 mengenai akad salam ini dapat diterapkan pada semua lembaga keuangan syariah seperti perbankan syariah, lembaga pembiayaan syariah, asuransi syariah dan lembaga lainnya. Dan pada PSAK 103 mengkaji mengenai akuntansi dari sisi penjual dan pembeli dengan tidak membedakan siapa pelakunya. Sedangkan dalam PSAK no.59 diperuntukkan hanya pada bank syariah baik akuntansi bank syariah sebagai penjual maupun pembeli. 


\section{E. Akun Transaksi Pembiayaan Salam}

1. Beberapa akun pada penjual dalam transaksi salam.

a. Akun-akun atas laporan posisi keuangan (Neraca)

1) Hutang Salam (Kewajiban Salam)

Pencatatan atas pembayaran harga barang yang telah di sepakati oleh pembeli. Pada prinsipnya kewajiban salam ialah hutang barang bukan uang. Berada pada kredit ketika menerima pembayaran harga sebesar harga keseluruhan barang yang diterima, sedangkan disisi debet saat penyerahan barang yang dipesan ${ }^{41}$.

2) Persediaan (Aset salam) Pencatatan atas barang salam yang selesai dibuat atau telah diterima, kemudian diserahkan ke pembeli akhir. Di ketika di

${ }^{41}$ Sofyan S Hrahap, Wiroso, Muhammad Yusuf, Akuntansi Perbankan Syariah (Jakarta: KPFE Usakti, 2006). 
terima barang salam. Dan ada

di Kredit ketika penyerahan barang kepada pembeli akhir.

3) Hutang kepada LKS

Digunakan dalam pencatatan hutang produsen atas tidak dapat diserahkannya barang pesanan pada saat jatuh tempo. Akun ini disisi kredit ketika di pindahkan dari hutang salam ke hutang LKS, dan disisi debet ketika dilakukan pembayaran. ${ }^{42}$

b. Akun-akun Laba Rugi

1) Keuntungan Penyerahan Aktiva

Untuk mencatat keuntungan penyerahan modal salam berupa barang (non-kas) yang nilai pasarnya lebih tinggi daripada nilai perolehan. Akun ini berada di debet saat terjadi keuntungan atas penyerahan barang sebesra selisih harga pasar dengan harga

${ }^{42}$ Rizal Yahya, Akuntansi Perbankan Syariah (Jakarta: Salemba Empat, 2009). 
perolehan, dan disisi kredit ketika dipindahkan ke akun laba rugi. ${ }^{43}$

2) Kerugian Penyerahan Aktiva Akun ini untuk mencatat kerugian penyerahan modal salam berupa barang (nonkas) yang nilai pasarnya lebih rendah daripada nilai perolehan. Akun ini disisi kredit pada saat terjadi keuntungan atas penyerahan barang sebesra selisih harga pasar dengan harga perolehan, sedangkan disisi debet pada saat dipindahkan ke akun laba rugi.

3) Kerugian salam

Akun ini untuk mencatat kerugian yang terjadi dalam transaksi salam. Berada disisi debet pada saat timbul kerugian dan disisi kredit pada saat dipindahkan ke akun laba rugi pada tutup buku akhir tahun. ${ }^{44}$ salem

${ }^{43}$ Wiroso, Akuntansi Transaksi Syariah.

${ }^{44}$ Yahya, Akuntansi Perbankan Syariah. 


\section{4) Keuntungan salam}

Akun ini untuk mencatat keuntungan yang terjadi dalam transaksi salam. Keuntungan ini hanya dapat dibukukan saat penyerahan barang atau perubahan risiko yang signifikan dari penjual ke pembeli. Berada disisi kredit pada saat timbul kerugian dan disisi debet saat dipindahkan ke akun laba rugi pada tutup buku akhir tahun. ${ }^{45}$

2. Akun-akun pada pembeli dalam transaksi salam.

a. Akun pada laporan posisi keuangan (Neraca)

1) Piutang Salam

Pencatatan untuk pembayaran harga kepada produsen (pembuat barang) sesuai besar jumlah harga yang di sepakati saat akad. Akun ini disisi debet ketika ada pembayaran harga barang. Dikredit ketika

${ }^{45} \mathrm{lbid}$. 
pelunasan piutang atau penyerahan barang pesanan.

2) Persediaan (asset salam) Pencatatan atas barang pada transaksi akad salam. Berada disisi debet ketiika menerima barang dan dikredit saat penyerahan barang ke pemesan. ${ }^{46}$

3) Piutang kepada petani Untuk mencatat kewajiban produsen ketika akhir akad tidak dapat menyerahkan barang pesanan. Akun ini merupakan piutang berupa uang bukan piutang atas barang. Akun ini berada disisi debet pada saat akhir akad dan produsen tidak bisa menyerahkan barang pesanan sedangkan disisi kredit pada saat melakukan pembayaran. ${ }^{47}$

2. Akun-akun Laba Rugi

\footnotetext{
${ }^{46}$ Wiroso, Akuntansi Transaksi Syariah.

${ }^{47}$ Sofyan S, Harahap, Wiroso, Muhammad Yusuf, Akuntansi Perbankan Syariah (Jakarta: KPFE Usakti, 2006).
} 
1) Keuntungan penyerahan asset salam

Pencatatan atas keuntungan yang diperoleh saat penyerahan modal berupa barang dimana nilai tersebut lebih kecil dari nilai wajar. Berada di kredit saat dilakukan penyerahan modal non-kas dan disisi debet ketika tutup buku yang diperhitungkan ke pendapatan usaha. ${ }^{48}$

2) Kerugian penyerahan asset salam

Digunakan dalam mencatat kerugian akibat penyerahan modal berupa barang dimana nilainya lebih besar dari nilai wajar saat penyerahan barang. Akun ini disisi debet saat terjadi penyerahan modal non-kas dan disisi kredit saat tutup buku dipindahkan atau

${ }^{48}$ Sofyan s, Akuntansi Perbankan Syariah. 


\section{Contoh ilustrasi :}

1. Pada 9 Maret 2015 PT. Dahlia Purnama membutuhkan 50 ton tepung ketela type A. kemudian PT Dahlia Purnama membeli tepung ketela dengan transaksi salam kepada Bank Amanah Syariah dengan rincian:

Spesifikasi barang pesanan

Tepung Ketela type B

$$
\text { Jumlah barang }
$$$$
\text { : } 30
$$

ton

Modal / harga : $\mathrm{Rp}$ 150.000.000 ( Rp 5.000.000 per ton)

\section{Jangka wakltu}

tahap setiap dua bulan sekali sebanyak 10 ton (9 Mei, 9 Juli dan 9 September 2015

Penyerahan modal : Dilunasi pada saat akad ditanda-tangani.

2. Dalam memenuhi kebutuhan PT Dahlia Purnama, Bank Amanah Syariah dapat memebli kebutuhan tersebut kepada 
petani. BAS melakukan transaksi kepada petani dengan rincian data sebagai berikut :

Spesifikasi barang pesanan: Tepung Ketela type B

Jumlah barang : 30 ton

Modal / harga $\mathrm{Rp}$ 120.000.000 ( Rp 4.000.000 per ton)

Penyerahan modal : Uang tunai sebesar Rp 100.000.000

Alat pertanian sebesar Rp 20.000.000

Agunan : Sebidang sawah senilai Rp 100.000.000

Cara penyerahan : Tiga tahap setiap dua bulan sekali sebanyak 10 ton (9 Mei, 9 Juli dan 9 September 2015)

Akuntansi Salam - Bank Sebagai Penjual 


\section{Penerimaan modal salam}

Atas penerimaan modal salam yang diterima penjual telah diatur dalam PSAK 103 paragraf 17 s.d 19, yaitu ${ }^{49}$ :

a) Diakui hutang salam apabila bank atau penjual telah menerima modal salam dari pembeli.

b) Modal salam yang diterima dapat berbentuk kas dan asset non-kas. Modal berupa kas diukur sebesar jumlah yang diterima, sedangkan modal berupa non-kas diukur sebesar nilai wajar (nilai yang disepakati oleh kedua belah pihak).

c) Apabila bank atau penjual melakukan transaksi salam paralel, terdapat selisih antara jumlah yang dibayar oleh pembeli dengan biaya perolehan barang.

d) Pesanan dapat diaku sebagi kerugian atau keuntungan ketika dilakukan penyerahan barang pesanan oleh penjual ke si pembeli.

${ }^{49}$ PSAK 103,Pedoman Standar Akuntansi Perbankan Syariah, (Jakarta : Ikatan Akuntansi Indonesia.2007) 
Dari contoh ilustrasi diatas saat penerimaan dana dari pembeli, penjurnalan yang dilakukan oleh penjual atau bank sebagai berikut :

Db. Kas/ Rek nasabah

$\mathrm{Rp}$

150.000 .000

Kr. Hutang Salam

$\mathrm{Rp}$

150.000 .000

Buku Besar

Hutang Salam

Debet

\begin{tabular}{|c|c|c|c|c|c|}
\hline $\mathrm{Tgl}$ & Ketrangan & Jumlah & Tgl & Ketrangan & Jumlah \\
\hline & \multirow[t]{2}{*}{ Saldo } & $\begin{array}{l}\mathrm{Rp} \\
150.000 .000\end{array}$ & \multirow[t]{2}{*}{$\begin{array}{l}9 / \\
3\end{array}$} & \multirow[t]{2}{*}{$\begin{array}{l}30 \text { ton } \\
\text { Tepung } \\
\text { ketela type } \\
\text { B }\end{array}$} & $\begin{array}{c}\mathrm{Rp} \\
150.000 \\
000\end{array}$ \\
\hline & & $\begin{array}{l}\mathrm{Rp} \\
150.000 .000\end{array}$ & & & $\begin{array}{c}\mathrm{Rp} \\
150.000 \\
000\end{array}$ \\
\hline
\end{tabular}


Neraca

Per 9 Maret 2015

\begin{tabular}{|l|l|l|l|}
\hline Uraian & Jumlah & \multicolumn{1}{|c|}{ Uraian } & \multicolumn{1}{|c|}{ Jumlah } \\
\hline & & Hutang Salam & $\mathrm{Rp}$ \\
& & & 150.000 .000
\end{tabular}

2. Penyerahan barang pesanan oleh Bank kepada pembeli.

Pada saat penyerahan barang pesanan oleh penjual atau bank kepada pemesan di setiap dua bulan sekali, jurnal yang dilakukan oleh penjual sebagai berikut (10 ton $x$ Rp 5.000.000 = 50.000.000):

Db. Hutang Salam

$\mathrm{Rp}$

50.000.000

Kr. Persediaan

$\mathrm{Rp}$

50.000 .000

Buku Besar

Hutang Salam 
Debet

Kredit

\begin{tabular}{|c|c|c|c|c|c|}
\hline Tgl & Keterangan & Jumlah & Tgl & $\begin{array}{c}\text { Keterang } \\
\text { an }\end{array}$ & Jumlah \\
\hline \multirow{9}{*}{$\begin{array}{l}9 / 5 \\
9 / 7 \\
9 / 9\end{array}$} & \multirow{9}{*}{$\begin{array}{l}10 \text { ton tepung } \\
\text { ketela type } B\end{array}$} & 50.000 .0 & \multirow[t]{9}{*}{$9 / 3$} & \multirow{9}{*}{$\begin{array}{l}30 \text { ton } \\
\text { Tepung } \\
\text { ketela } \\
\text { type B }\end{array}$} & 150.000. \\
\hline & & 00 & & & 000 \\
\hline & & 50.000 .0 & & & \\
\hline & & & & & \\
\hline & & 50.000 .0 & & & \\
\hline & & 00 & & & \\
\hline & & $\mathrm{Rp}$ & & & $\mathrm{Rp}$ \\
\hline & & 150.000. & & & 150.000. \\
\hline & & 000 & & & 000 \\
\hline
\end{tabular}

Neraca

Per 9 Mei 2015

\begin{tabular}{|l|l|l|l|}
\hline Uraian & Jumlah & \multicolumn{1}{|c|}{ Uraian } & Jumlah \\
\hline & & $\begin{array}{l}\text { Hutang } \\
\text { Salam }\end{array}$ & 00 \\
\hline
\end{tabular}

Akuntasi Salam - Bank sebagai Pembeli 


\section{Penyerahan Modal Salam}

Dalam kebijakan Dewan Syariah Nasional nomor 05/DSN-MUI /IV/2000 mengenai Jual Beli Salam dengan ketentuan pembayaran sebagai berikut ${ }^{50}$ :

Pertama : Ketentuan mengenai penmbayaran.

a. Alat pembayaran harus diketahio bentuk dan jumlahnya, bentuk tersebut dapat berupa uang, barang (manfaat).

b. Pembayaran dilaksanakan saat kontrak (akad) terjadi.

c. Pembayaran angsuran tidak boleh berbentuk pembebasan hutang.

Perlakuan akuntansi dalam modal salam juga telah diatur dalam PSAK 103 paragraf 11 dan 12 , sebagai berikut ${ }^{51}$ :

11. Piutang salam diakui ketika modal usaha dibayarkan atau dipindahkan kepada penjual.

${ }^{50}$ Mubarok, Jaih, Fikih Mu'amaliyah Maliyyah Akad Jual Beli. 51 PSAK 103,Pedoman Standar Akuntansi Perbankan Syariah, (Jakarta : Ikatan Akuntansi Indonesia.2007) 
12. modal usaha salam dapat berupa kas dan asset non-kas. Modal usaha berupa kas nilainya sebesar jumlah yang dibayarkan, sedangkan modal salam berupa asset non-kas diukur sebesar nilai wajar (nilai yang telah disepakati antara bank dan nasabah)

Pada prinsipnya mengenai transaksi salam dijelaskan bahwa penyerahan barang dilaksanakan secara tangguh (kemudian)tetapi penyerahan modal usaha diserahkan saat akad atau kontrak disepakati.

a. Apabila modal salam berupa uang tunai (kas). Maka jurnal yang dilakukan sebagai berikut (pada contoh ilutrasi no.2):

Db. Piutang Salam Rp

120.000 .000

Kr. Kas/rekening Rp

120.000 .000

\section{Piutang Salam}

Debet

Kredit 


\begin{tabular}{|c|c|c|c|c|c|}
\hline Tgl & Ktrngan & Jumlah & Tgl & Ktrngn & Jumlah \\
\hline \multirow[t]{2}{*}{$9 / 3$} & $\begin{array}{l}\text { Modal } \\
\text { Kas }\end{array}$ & $\begin{array}{l}\mathrm{Rp} \\
120.000 .000\end{array}$ & & Saldo & $\begin{array}{c}\mathrm{Rp} \\
120.000 .000\end{array}$ \\
\hline & & $\begin{array}{l}\mathrm{Rp} \\
120.000 .000\end{array}$ & & & $\begin{array}{c}\mathrm{Rp} \\
120.000 .000\end{array}$ \\
\hline
\end{tabular}


Neraca

Per 9 Maret 2015

\begin{tabular}{|c|l|l|l|}
\hline Uraian & \multicolumn{1}{|c|}{ Jumlah } & Uraian & Jumlah \\
\hline Piutang Salam & $\begin{array}{l}\mathrm{Rp} \\
120.000 .000\end{array}$ & & \\
\hline
\end{tabular}

b. Apabila modal salam uang tunai dan juga berupa asset non-kas (dibeli dengan harga perolehan yang lebih kecil, misal Rp 18.000.000), maka jurnal yang dicatat ialah- Contoh Ilustrasi 2:

Db. Piutang Salam Rp

120.000.000.

Kr. Kas/ rekening Rp

100.000.000

Kr. Aset/ persediaan $\mathrm{Rp}$

18.000.000

$\mathrm{Kr}$. Keuntungan pnyrhn Rp

2.000.000

Piutang Salam

Debet

Kredit 


\begin{tabular}{|c|c|c|c|c|c|}
\hline TgI & Ktrngn & Jumlah & Tgl & Ktrngn & Jumlah \\
\hline \multirow[t]{2}{*}{$9 / 3$} & $\begin{array}{l}\text { Modal Kas } \\
\text { Alat pertanian }\end{array}$ & $\begin{array}{l}100.000 .000 \\
20.000 .000\end{array}$ & & \multirow[t]{2}{*}{ Saldo } & $\begin{array}{l}\text { RP } \\
120.000 .000\end{array}$ \\
\hline & & $\begin{array}{l}\mathrm{Rp} \\
120.000 .000\end{array}$ & & & 120.000 .000 \\
\hline
\end{tabular}

Neraca

Per 9 Maret 2015

\begin{tabular}{|c|l|l|l|}
\hline \multicolumn{1}{|c|}{ Uraian } & \multicolumn{1}{|c|}{ Jumlah } & Uraian & Jumlah \\
\hline Piutang Salam & $\begin{array}{l}\mathrm{Rp} \\
120.000 .000\end{array}$ & & \\
\hline
\end{tabular}

c. Apabila modal salam uang tunai dan juga berupa asset non-kas (dibeli dengan harga perolehan yang lebih kecil, misal Rp 23.500.000), maka jurnal yang dicatat ialah- Contoh Ilustrasi 2:

Db. Piutang Salam Rp

120.000.000.

Kr. Keuntungan pnrhyn Rp

3.500 .000 


$\begin{array}{ll}\text { Kr. Kas/ rekening } & R p \\ 100.000 .000 & \\ \text { Kr. Aset/ persediaan } & R p \\ 23.500 .000 & \end{array}$

\section{Penerimaan Barang Pesanan}

Pada prinsipnya barang pesanan dalam transaksi salam harus sesuai spesifikasinya yang ada dalam kontrak (akad).

Dalam PSAK 103 membahas mengenai penermaan barang pesanan pada transaksi salam, sebagai berikut :

a. Apabila barang pesanan sesuai dengan akad.

Pada tanggal 9 Mei 2015 dan 9 Juli 2015, petani menyerahkan pesanan tepung ketela type $B$ masing-masing 10 ton - nilai wajar sama dengan kontrak (10 $\mathrm{x}$ Rp 4.000.000). Maka jurnal yang dilakukan pada dua bulan itu ialah :

Db. Persedian salam Rp 40.000 .000

Kr. Piutang Salam Rp 40.000.000

\section{Buku Besar}

\section{Piutang Salam}


Debet

Kredit

\begin{tabular}{|c|c|c|c|c|c|}
\hline Tgl & Ktrngn & Jumlah & Tgl & Ktrngn & Jumlah \\
\hline \multirow[t]{2}{*}{$9 / 3$} & $\begin{array}{l}\text { Modal Kas } \\
\text { Alat } \\
\text { pertanian }\end{array}$ & $\begin{array}{l}100.000 .000 \\
20.000 .000\end{array}$ & $\begin{array}{l}9 / 5 \\
9 / 7 \\
9 / 9\end{array}$ & $\begin{array}{l}\text { Penyerah } \\
\text { an I } \\
\text { Penyerah } \\
\text { an II } \\
\text { Penyerah } \\
\text { an III }\end{array}$ & $\begin{array}{c}\mathrm{Rp} \\
40.000 .000 \\
\mathrm{Rp} \\
40.000 .000 \\
\mathrm{Rp} \\
40.000 .000\end{array}$ \\
\hline & & 120.000 .000 & & & $\begin{array}{c}\mathrm{Rp} \\
120.000 .000\end{array}$ \\
\hline
\end{tabular}

Neraca

Per 9 Maret 2015

\begin{tabular}{|l|l|l|l|}
\hline \multicolumn{1}{|c|}{ Uraian } & \multicolumn{1}{|c|}{ Jumlah } & Uraian & Jumlah \\
\hline Piutang Salam & $\mathrm{Rp}$ & & \\
Persediaan & 20.000 .000 & & \\
salam & $\mathrm{Rp}$ & & \\
& 100.000 .000 & & \\
\hline
\end{tabular}


b. Jika pesanan berbeda kualitas dengan yang tercantum pada akad

1) Apabila nilai wajar lebih tinggi - Rp 5.000 .000 (tepung ketela Type A) dari nilai kesepakatan, maka dibuat jurnal sebagai berikut:

Db. Persediaan Salam Rp $\quad 50.000 .000$ (tepung ketela type A) Kr. Piutang Salam

50.000 .000

2) Apabila nilai wajar lebih rendah $\mathrm{Rp}$ 3.500.000(tepung ketela Type C) dari nilai kesepakatan, maka dibuat jurnal sebagai berikut :

Db. Persediaan Salam $\mathrm{Rp}$

35.000 .000

Db. Kerugian penerimaan barang salam

5.000 .000 
Kr. Piutang Salam
Rp 40.000 .000

c. Apabila bank (pembeli) tidak menerima barang pesanan baik sebagian maupun keseluruhan pada masa jatuh tempo.

1) Jika waktu diperpanjang, nilai piutang salam tercatat sebesar nilai barang yang belum diterima dengan sesuai yang tercantum dalam akad, maka jurnal yang dibuat ialah :

Db. Kas $\quad x x x$

Db. Piutang petani (industry) $\mathrm{xxx}$

Kr. Piutang salam $x x x$

2) Jika akad salam dibatalkan sebagian atau seluruhnya maka piutang salam berubah menjadi piutang yang harus dilunasi oleh petani sebesar bagian yang tidak 
diterima itu, maka jurnal yang dibuat ialah :

Db. Piuang Petani (industry) $\mathrm{xxx}$

Kr. Piutang salam

XXX

3) Jika bank mempunyai jaminan (sebidang sawah) atas barang pesanan untuk melunasi hutang petani (penjual).

a) Piutang salam merupakan Hasil penjualan jaminan. Maka dari hasil tersebut dapat dibuat jurnal : Db. Kas $\quad x x$ Kr. Piutang Salam $\mathrm{xx}$

\section{Piutang Salam}

Debet

Kredit

Tgl




\begin{tabular}{|c|c|c|c|c|c|}
\hline $9 / 3$ & $\begin{array}{l}\text { Modal Kas } \\
\text { Alat } \\
\text { pertanian }\end{array}$ & $\begin{array}{l}100.000 .000 \\
20.000 .000\end{array}$ & $\begin{array}{l}9 / 5 \\
9 / 7 \\
9 / 9 \\
1 / 10\end{array}$ & $\begin{array}{l}\text { Penyer } \\
\text { ahan I } \\
\text { Penyer } \\
\text { ahan II } \\
\text { Penyer } \\
\text { ahan III } \\
\text { Peluna } \\
\text { san }\end{array}$ & $\begin{array}{c}\mathrm{Rp} \\
40.000 .000 \\
\mathrm{Rp} \\
40.000 .000 \\
\mathrm{Rp} \\
40.000 .000\end{array}$ \\
\hline & & $\begin{array}{l}\mathrm{Rp} \\
120.000 .000\end{array}$ & & & $\begin{array}{c}\mathrm{Rp} \\
120.000 .000\end{array}$ \\
\hline
\end{tabular}

Neraca

\begin{tabular}{|c|c|c|c|}
\hline Uraian & Jumlah & Uraian & Jumlah \\
\hline Piutang Salam & 0 & & \\
\hline
\end{tabular}

b) Hasil penjualan jaminan lebih kecil dari piutang salam. Maka dari hasil tersebut dapat dibuat jurnal

Db. Kas

xxx

Db. Piutang kelompok petani $x x x$ 
Kr. Piutang Salam

$x x x$

c) Hasil penjualan jaminan lebih tinggi dari piutang salam. Maka dari hasil tersebut dapat dibuat jurnal

Db. Kas $\quad x x x$

Kr. Rekening kelompok petani

$\mathrm{xxx}$

Kr. Piutang Salam $\quad x x x$

4) Bank dapat memberlakukan denda kepad penjual agar tidak menyalahi akad yang telah dibuat. Dalam PSAK 103 paragraf 15 telah diatur sebagai berikut :

15. Pembeli dapat memberlakukan denda ke penjual, denda tersebut hanya untuk penjual yang asalnya mampu untuk menyelesaikan kewajiban tetapi tidak memenuhinya. Denda tersebut tidak berlaku untuk penjual yang tidak mampu memenuhi kewajiban karena force 
majeur. Denda tersebut

diakui sebagai dana kebajikan.

Atas denda tersebut, dapat dibuat jurnal sebagai berikut

Db. Rekening petani $x x x$

Kr. Rekening ZIS (dana kebajikan)

$\mathrm{xxX}$

\section{F. Rangkuman}

Akad salam adalah akad jual beli dimana uang muka dan pengiriman secara tangguh. Walaupun barang diserahkan dikemudian hari namun ketika akad telah ditentukan terkait spesifikasi, harga, kualitas, dan kuantitas, serta waktu penyerahan. Sehingga tidak ada unsure ketidakjelasan dan riba. Hal inilah yang membedakan salam dengan transaksi ijon.

Selain akad salam biasa ada juga terdapat akad salam paralel. Dimana akad ini merupakan akad yang barangnya tidak dimiliki oleh penjual dan harus memesan kepada pemasok lain sesuai spesifikasi. Akad ini diperbolehkan oleh syariah islam tetapi diantara kedua akad tersebut tidak saling tergantung, 
selain itu akad antara penjual dan pemasok harus terpisah dari akad pembeli dan penjual.

Rukun pembiayaan salam yaitu :

1. Muslam, yaitu orang yang memesan barang.

2. Muslam Ilaihi, yaitu orang yang memiliki barang atau penjual atau pemasok.

3. Musalm Fiihi, objek atau barang yang di akadkan.

4. Modal

5. Sighat akad, ijab dan qabul.

Alur transaksi pembiayaan salam yaitu :

1. Muslam bertransaksi dengan penjual untuk membeli kebutuhannya dengan memberikan spesifikasi barang yang akan dibeli.

2. Dalam transaksi pertama tersebut terjadi negoisasi anatara Muslam Ilaihi (penjual) dengan Muslam, dan ketika sepakat terjadilah akad salam.

3. Pada saat akad telah sah pembeli harus menyerahkan harga atas barang pesanan tersebut secara tunai.

4. Setelah terjadi akad salam dan pembayaran maka pihak penjual akan melakukan produksi sesuai spesifikasi barang pesanan. 


\section{G. Studi Kasus Transaksi Pembiayaan Salam}

\section{Soal kasus 1 :}

Pada tanggal 10 Januari 2020 Bank syariah A melakukan transaksi dengan kelompok petani di Bojonegoro dengan data pesanana sebagai berikut :

Nama barang pesanan

Jenis barang pesanan

Jumlah barang

Modal / harga

45.000.000 per ton)

Jangka waktu penyerahan

syariah A

Penyerahan modal

akad ditanda-tangani.

Diminta :

Buatlah Jurnal dan perhitungan atas transaksi diatas!

\section{Soal kasus 2 :}

Bank Husna syariah dipercaya oleh Bulog untuk pembelian beras, dengan data:

Nama barang pesanan

: Tepung ketela type B
: Bawang merah

: Kualitas Ekspor A+

: 30 ton

: Rp 450.000.000 ( Rp

: 6 bulan sampai bank

: Dilunasi pada saat $B$ 
Jenis barang pesanan

Jumlah barang

Modal / harga

8.000.000 per ton)

Jangka waktu penyerahan
: Type B kada air $10 \%$

: 100 ton

: Rp 800.000.000 ( Rp

: 5 bulan

Untuk memenuhi pesanan dari Bulog, Bank Husna syariah melakukan pemesanan beras kepada KUD Makmur, dengan data sebagai berikut :

Nama barang pesanan : Tepung ketela type B

Jenis barang pesanan : Type B kada air $10 \%$

Jumlah barang : 100 ton

Modal / harga : Rp 700.000.000 ( Rp 7.000.000 per ton)

Penyerahan modal : Uang tunai sebesar Rp 500.000.000

Alat pertania sebesar Rp 100.000.000

Agunan

: Sebidang sawah senilai Rp 800.000.000 
Cara penyerahan : Secara bertahap masing-masing 20 ton setiap bulan.

Dengan Catatan :

1. Apabila pada penyerahan tahap 1 s.d 3 barang yang diserahkan sesuai dengan yang tercantum dalam akad.

2. Pada penyerahan ke 4 terjadi perbedaan kualitas barang yang dikirim.

Penyerahan 20 ton tepung ketela Type D kadar air $10 \%$ dengan harga pasar sebesar Rp 5.000.000 per ton

3. Pada penyerahan ke 5 penyerahan 20 ton tepung ketela type A kadar air 20\% dengan harga pasar sebesar Rp 9.250.000 per ton.

Diminta :

Buatlah Jurnal dan perhitungan atas transaksi diatas! 


\section{BAB V}

\section{TEORI DAN PRAKTEK AKUNTANSI TRANSAKSI ISTISHNA}

\section{Kompetensi Dasar}

Setelah mempelajari bab ini, diharapkan membentuk mahasiswa yang kompeten dalam hal berikut :

1. Mampu melakukan pencatatan transaksi akuntansi dengan akad istishna' dan istishna' paralel

2. Pemahaman terhadap pengakuan dan pengukuran, pengungkapan serta penyajian akuntansi istishna' dan istishna' paralel.

\section{Indikator}

Indikator yang ada dalam bab ini, sebagai berikut :

1. Kemampuan proses akuntansi untuk transaksi akad istishna' dan istishna' paralel

\section{Materi Pokok}

Materi utama pada bab ini adalah Akuntansi penyaluran dana dengan akad istishna' dan istishna' paralel. 


\section{A. Definisi Istishna}

Menurut bahasa yang berasal dari kata صنع) shana'a) yang berarti membuat selanjutnya ditambah dengan huruf alif, sin dan ta' yang menjadi استصنع) istashna'a) artinya meminta dibuatkan sesuatu. Transaksi jual beli istishna' merupakan kontrak penjualan antara mustashni' (pembeli) dan shani' (pembuat barang/penjual). Dalam kontrak ini shani' menerima pesanan dari mustashni'. Shani' lalu berusaha sendiri ataupun melalui orang lain untuk membuat mashnu' (pokok kontrak) menurut spesifikasi yang telah disepakati dan menjualnya kepada mustashni'. Kedua belah pihak bersepakat atas harga serta sistem pembayaran ${ }^{52}$

Istishna adalah akad jual beli dimana produsen ditugaskan untuk membuat suatu barang pesanan dari pemesan. Istishna adalah akad jual beli atas dasar pesanan antar nasabah dan bank dengan spesifikasi tertentu yang diminta oleh nasabah. Bank akan meminta produsen untuk membuatkan barang pesanan sesuai dengan permintaan nasabah. Setelah selesai nasabah akan membeli barang tersebut

52 Syafi'i Antonio Muhammad, Bank Syariah dari Teori ke Praktek, (Jakarta: Gema Insani, 2001), h.145 
dari bank dengan harga yang telah disepakati bersama ${ }^{53}$.

Al-Istishna' adalah akad jual beli pesanan antara pihak produsen /pengrajin/penerima pesanan (shani') dengan pemesan (mustashni') untuk membuat suatu produk barang dengan spesifikasi tertentu (mashnu') dimana bahan baku dan biaya produksi menjadi tanggungjawab pihak produsen sedangkan sistem pembayaran bisa dilakukan di muka, tengah atau akhir.

Al-Istishna merupakan akad kontrak jual beli barang antara dua pihak lain, dan barang pesanan akan diproduksi sesuai dengan spesifikasi yang telah disepakati dan menjualnya dengan harga dan pembayaran yang disetujui terlebih dahulu. Istina adalah akad penjualan antara al-Mustashni (pembeli) dan as-Shani (produsen yang juga bertindak sebagai penjual). Berdasarkan akad Istishna pembeli menugasi prosuden untuk membuat atau mengadakan al-Mashni (barang pesanan) sesuai spesifikasi yang disyaratkan dan menjualnya dengan harga yang disepakati ${ }^{54}$.

\section{Gita Danupranata, Manjaemen Perbankan}

Syariah,(Jakarta:Salemba Empat, 2013), h.112

${ }^{54}$ Ismail, PerbankanSyariah, (Jakarta:Prenada Media Group, 2011), h. 146 
Salah satu produk yang juga populer digunakan dalam perbankan syariah adalah produk isitshna'. Akad istishna' ini hukumnya boleh (jawaz) dan telah dilakukan oleh masyarakat Muslim sejak masa awal tanpa ada pihak (ulama) yang mengingkarinya. Akad isitshna' biasanya dipraktikan pada pembiayaan perbankan syariah dalam proyek konstruksi, maka hal ini sangat cocok dengam kebutuhan nasabah untuk membangun suatu kontruksi salah satunya membangun rumah ${ }^{55}$.

Dari beberapa uraian diatas dapat disimpulkan bahwa Istishna' merupakan akad yang mengandung tuntutan agar tukang/ahli (shani) membuatkan suatu pesanan dengan ciriciri khusus, dimana spesifikasi dan harga barang disepakati di awal sedangkan pembayaran dilakukan secara bertahap sesuai kesepatan.

\section{B. Rukun Pembiayaan Istishna}

Menurut pendapat Gita Danupranata rukun istishna adalah ada pembuat/produsen, ada pemesan/pembeli, ada barang atau proyek yang dipesan, ada kesepakatan haraga jual dan ada pengikatan. Sedangkan syarat istishna adalah pihak yang berakad harus paham hukum, produsen sanggup memenuhi persyaratan

55 Usma Rachamadi, Produk dan Akad Perbankan Syraiah di Indonesia, (Bandung: PT Citra Aditya Bakti, 2009), h.197 
pemesanan, objek yang dipesan jelas spesifikasinya, harga jual adalah harga pesanan ditambah keuntungan, harga jua tetap selama jangka waktu pemesanan dan jangka waktu pembuatan disepakati bersama.

Sedangkan menurut pendapat Ascarya rukun dari akad istishna yang harus dipenuhi dalam transaksi adalah, Pertama pelaku akad yaitu mustashni' (pembeli) adalah pihak yang membutuhkan dan memesan barang dan shani' (penjual) adalah pihak yang memproduksi barang pesanan. Kedua objek akad yatiu barang atau jasa (mashnu') dengan spesifikasinya dan harga (tsaman), dan Ketiga, Shigha yaitu ijab dan qobul. Menurut pendapat Imam Syafii Antonio Rukun istishna" adalah sebagai berikut :

a. Al-mustashni (pembeli/pemesan)

1) Hendaknya menentukan jenis, bentuk dan sifat yang dipesan.

2) Tidak boleh menjual barang sebelum menerimanya.

3) Dalam hal terdapat cacat atau barang tidak sesuai dengan kesepakatan, pemesan memiliki hak pemilih untuk melanjutkan atau membatalkan akad.

b. As-shani (penjual)

1) Boleh menjual barang yang dibuat oleh orang lain yang mempunyai 
kualitas dan kuantitas yang dikehendaki oleh pemesan.

2) Tidak boleh menukar barang kecuali dengan barang yang sejenis sesuai dengan kesepakatan barang yang dipesan.

c. Al-mashu (barang yang dijual)

1) Harus jelas ciri-cirinya

2) Barang yang dipesan hendaknya barang yang biasa dijual belikan secara pesanan oleh banyak orang.

3) Harus dapat dijelaskan spesifikasinya

4) Penyerahannya dilakukan kemudian

5) Waktu dan tempat penyerahan barang harus ditentukan berdasarkan kesepakatan

6) Bahan-bahan untuk membuat barang hendaknya dari pihak penjual

d. Harga

1) Harga barang yang dipesan boleh dibayar semua pada saat akad

2) Harga barang yang dipesan boleh dibayar semua pada saat penyerahan barang

3) Secara angsuran sesuai dengan kesepakatan 
4) Pembayaran tidak boleh dalam bentuk pembebasan utang

e. Sighat atau ucapan/ijab kabul. 
Sedangakan Syarat istishna' menurut Syafii Antonio adalah sebagai berikut :

a. Modal transaksi al-istishna"

1) Modal harus diketahui

2) Penerimaan pembayaran salam

b. Al-mashu (barang)

1) Harus spesifik dan dapat diakui sebagai utang

2) Harus bisa diidentifikasi secara jelas

3) Penyerahan barang dilakukan dikemudian hari

4) Kebanyakan ulama mensyaratkan penyerahan barang harus ditunda pada suatu waktu kemudian, tetapi mazhab syafi"i membolehkan penyerahan segera.

5) Boleh menentukan tanggal waktu dimasa yang akan datang untuk penyerahan barang

6) Tempat penyerahan

7) Penggantian muslam fiihi dengan barang lain. 


\section{Skema Pembiayaan Istishna}

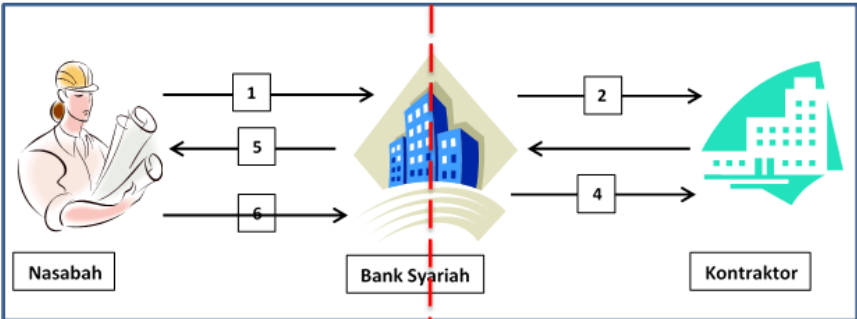

Jika dalam pembuatan barang yang dipesan oleh nasabah, LKS membuat sendiri maka skema transaksi akad istisna' adalah sebagai berikut :

1) Nasabah memesan barang kepada Bank Syariah untuk pembuatan suatu barang konstruksi

2) Bank syariah membuat barang pesanan, kemudian menyerahkan barang kepada nasabah

3) Nasabah melakukan pembayaran kepada bank syariah.

Jika untuk memenuhi pesanan nasabah tersebut bank syariah memesan lagi kepada pihak lain atau kontraktor. Akad antara nasabah dan bank syariah sebagai penjual harus terpisah dengan akad bank syariah sebagai pembeli dengan kontraktor. Skema yang digunakan adalah istisna' paralel sebagai berikut :

1) Nasabah memesan barang kepada Bank Syariah untuk pembuatan suatu barang konstruksi

2) Bank Syariah memesan barang yang dipesan nasabah kepada kontraktor 
3) Kontraktor menyerahkan barang kepada bank syariah

4) Bank syariah melakukan pembayaran kepada kontraktor

5) Bank syariah menyerahkan barang pesanan kepada nasabah

6) Nasabah melakukan pembayaran kepada bank syariah.

\section{Cakupan Akuntansi Pembiayaan Istishna}

Akuntansi istishna' diatur dalam Pernyataan Standar Keuangan ( PSAK ) no 104 tentang istishna'.terkait dengan pengakuan dan pengukuran transaksi, standar ini mengatur tentang penyatuan dan segmentasi akad, pendapatan istishna' dan istishna' parale, istishna'dengan pembayaran tangguh, biaya perolehan istishna', penyelesaian awal pengakuan taksiran rugi, perubahan pesanan dan tagihan.

\section{Akuntansi Sebagai Penjual}

\section{Penyatuan dan Segmentasi Akad}

1) Apabila akad istishna mencakup atas sejumlah aset dari pengakuan setiap aset yang diperlukan untuk suatu akad yang terpisah jika:

2) Bila suatu akad istishna mencakup sejumlah aset pengakuan dari setiap aset 
diperlakukan sebagai suatu akad yang terpisah jika:

3) Akad istishna dari satu atau beberapa kelompok pembeli harus tetap diperlakukan hanya sebagai satu akad istishnah jika :

a. Apabila dari kelompok akad tersebut dinegoisasikan dalam satu paket.

b. Apabila akad tersebut saling berhubungan sangat erat, maka akad tersebut merupakan akad tunggal dengan pembagian margin atas keuntungan dan dilakukannya secara serentak.

4) Jika terdapat pemesana tambahan dengan akad istishna yang terpisah, maka penambahan tersebut termasuk dalam akad terpisah jika :

a. Apabila aset tambahan tersebut berbeda secara signifikan dalam akad istishna diawal seperti desain, teknologi maupun fungsinya.

b. Harga pada aset tambahan harus dinegoisasikan tanpa mengikut sertakan harga akad sitishna diawal.

Pendapatan istishna dan istishna paralel 
Pendapatan akad istishna dapat diakui dengan cara menggunakan metode akad selesai. Akad istishna dapat disebut selesai apabila selesai dalam membuat barang pesanan hingga sampai diserahkan kepada nasabah atau pihak pembeli. jika dalam metode persentase penyelesaian digunakan maka :

a. Pendapatan akad istishna pada periode bersangkutan dapat diakui apabila bagian dari nilai dalam suatu akad sebanding dengan pekerjaan yang telah diselesaikan pada periode tersebut.

b. Terdapat pembagian margin pada keuntungan istishna yang diakui selama masa periode dalam pelaporan yang ditambahkan pada aset istishna atas penyelesaiannya

c. Saat akhir periode pada harga pokok istishna dapat diakui sebesar biaya pada istishna yang sudah dikeluarkan hingga pada periode tersebut.

d. jika estimasi persentase penyelesaian akad dan biaya untuk penyelesaiannya tidak dengan ditentukan secara rasional pada akhir periode laporan keuangan maka digunakan metode akad selesai dengan ketentuan sebagai berikut :

1) tidak adanya suatu pendapatan yang diakui hingga pekerjaan tersebut telah selesai. 
2) Tidak ada harga pokok dalam akad istishna yang dikaui hingga pekerjaan tersebut telah selesai

3) Tidak adanya keuntungan yang diakui pada akad istishna hingga pekerjaan tersebut telah selesai

4) Pada saat akhir penyelesaian dapat dikatakan sebagai pengakuan pendapatan istishna, harga pokok istishna serta keuntungan.

\section{Istishna dalam Pembayaran Penuh}

Jika yang digunakan metode persentase penyelesaian serta proses pelunasan menggunakan periode lebih dari satu tahun atas penyerahan barang pesanan, maka pengakuan pendapatan dibagi menjadi dua, yaitu:

1. margin keuntungan pada pendapatan barang pesanan dihitung dari akad istishna yang dilakukan secara tunai dan dapat diakui sesuai persentase penyelesaian

2. terdapat selisih nilai akad dan nilai tunai atas penyerahan yang diakui selama periode pelunasan secara proporsional sesuai dengan jumlah pembayaran. Proporsional yang dimaksud yaitu sesuai dengan paragraf 24-25 PSAK 102 : Akuntansi Murabahah 
Meskipun akad istishna dilakukan dalam bentuk pembayaran secara tangguh, maka penjual harus dapat menentukan nilai tukar pada akad istishna saat penyerahan barang pesanan sebagai dasar untuk mengakui margin keuntungan dalam proses pembuatan barang pesanan. Margindapat menunjukkan nilai tambahan atas hasil pada proses pembuatan barang pesanan. Sedangkan nilai akad pada akad istishna dilakukan dalam bentuk pembayaran secara langsung yaitu harga yang disepakati antara penjual dan pembeli di akhir. Hubungan antara biaya perolehan, nilai tunai, dan nilai akad diuraikan dalam contoh sebagai berikut:

\begin{tabular}{|l|l|}
\hline Biaya atas perolehan (biaya produksi) & $R p 1.000$ \\
\hline $\begin{array}{l}\text { Margin keuntungan pada pembuatan barang } \\
\text { pesanan }\end{array}$ & 200 \\
\hline $\begin{array}{l}\text { Nilai tunai saat melakukan penyerahan barang } \\
\text { pesanan }\end{array}$ & $\mathrm{Rp} 1.200$ \\
\hline $\begin{array}{l}\text { Nilai akad atas pembayaran dalam bentuk angsuran } \\
\text { dengan jangka waktu tiga tahun } 1.600\end{array}$ & \\
\hline $\begin{array}{l}\text { Selisih atas nilai akad dan nilai tunai yang diakui } \\
\text { dengan jangka waktu tiga tahun }\end{array}$ & 400 \\
\hline
\end{tabular}


Jika penggunaan metode akad selesai dan proses pelunasan yang dilakukan pada saat periode lebih dari satu tahun atas penyerahan barang pesanan maka pengakuan pendapatan terdapat dua bagian, yaitu:

1. Margin pada keuntungan pembuatan barang pesanan terhitung apabila istishna dilakukan secara tunai maka dapat diakui pada saat penyerahan barang pesanan

2. Selisih pada nilai akad dan nilai tunai atas penyerahan dapat diakui selama periode pelunasan secara proporsional sesuai dengan jumlah pembayaran

3. Tagihan pada setiap termin pembeli yang diakui dari sebagai piutang istishna dan termin istishna (istishna billing) pada pos lawannya. 
Penagihan termin dapat dilakukan penjual pada saat transaksi istishna yang sesuai dengan kesepakatan akad dan tidak selalu sesuai dengan persentase penyelesaian pembuatan barang pesanan.

\section{Biaya Pada Perolehan Istishna}

Biaya pada perolehan istishna terdapat menjadi :

1. Biaya langsung yaitu bahan baku dan tenaga kerja yang langsung digunakan untuk membuat barang pesanan

2. Biaya tidak langsung adalah biaya overhead, termasuk dalam biaya akad dan pra-akad

3. Biaya pra-akad dapat diakui sebagai beban tangguhan dan dapat diperhitungkan sebagai biaya istishna jika akad sudah disepakati. Namun jika akad tidak disepakati, maka biaya akan dibebankan pada periode berjalan.

4. Biaya perolehan istishna terjadi selama periode laporan keuangan yang diakui sebagai aset istishna atas penyelesaian saat terjadinya.

5. Beban umum dan administrasi, beban penjualan, serta biaya riset dan pengembangan bukan termasuk dalam biaya istishna

\section{Biaya Perolehan Pada Istishna Paralel}


Biaya istishna paralel terdapat menjadi :

1. Biaya perolehan barang pesanan sebesar tagihan produsen atau kontraktor kepada entitas;

2. Biaya tidak langsung adalah biaya overhead, termasuk pada biaya akad dan pra-akad

3. Semua biaya akibat produsen atau kontraktor tidak bisa memenuhi kewajibannya, jika ada

4. Biaya perolehan istishna parallel yang diakui sebagai aset istishna atas penyelesaian diterimanya tagihan pada produsen atau kontraktor senilai dengan jumlah tagihan. 


\section{Penyelesaian Awal}

Jika pembeli dilakukannya pembayaran sebelum tanggal jatuh tempo dan penjual memberikan potongan, maka potongan tersebut sebagai pengurang pendapatan istishna. Pengurangan pendapatan istishna akibat penyelesaian awal piutang istishna dapat diperlakukan sebagai :

1. Potongan secara langsung dan dikurangkan dari piutang istishna pada saat pembayaran; atau

2. Penggantian (reimbursed) kepada pembeli sebesar jumlah keuntungan yang dihapuskan tersebut setelah menerima pembayaran piutang istishna secara keseluruhan

\section{Perubahan Pesanan dan Tagihan Tambahan}

Pengaturan pengakuan dan pengukuran atas pendapatan dan biaya istishna akibat perubahan pesanan dan tagihan tambahan adalah sebagai berikut :

1. Nilai dan biaya akibat perubahan atas pesanan yang disepakati oleh penjual dan pembeli ditambahkan kepada pendapatan istishna dan biaya istishna;

2. Jika kondisi pengenaan setiap tagihan tambahan yang dipersyaratkan dipenuhi, maka 
jumlah biaya setiap tagihan tambahan yang diakibatkan oleh setiap tagihan akan dapat menambah biaya istishna; sehingga pendapatan istishna menjadi berkurang sebesar jumlah penambahan pada biaya akibat klaim tambahan

3. Perlakuan akuntansi (a) dan (b) juga berlaku pada istishna paralel, akan tetapi biaya saat perubahan pesanan dan tagihan tambahan ditentukan pada produsen atau kontraktor dan disetujui penjual berdasarkan pada akad istishna parallel.

\section{Pengakuan Taksiran Rugi}

Jika besar kemungkinan terjadi bahwa total biaya perolehan istishna akan dapat melebihi pendapatan istishna, taksiran kerugian harus segera diakui. Jumlah kerugian semacam itu ditentukan tanpa memperhatikan:

1. Apakah pekerjaan istishna telah dilakukan atau belum;

2. Tahap penyelesaian pembuatan barang pesanan; atau

3. Jumlah laba yang diharapkan dari akad yang tidak diperlakukan sebagai suatu akad tunggal sesuai paragraf. 


\section{Akuntansi Sebagai Pembeli}

Akuntansi transaksi istishna dari sudut pandang pembeli antara lain sebagai berikut:

1. Pembeli mengakui aset istishna atas penyelesaian sebesar jumlah terminan yang ditagih oleh penjual dan sekaligus mengakui hutang istishna kepada penjual.

2. Aset istishna dapat diperoleh melalui dengan transaksi istishna dengan pembayaran tangguh lebih dari satu tahun diakui sebesar biaya perolehan tunai. Selisih antara harga beli yang disepakati dalam akad istishna tangguh dan biaya perolehan tunai diakui sebagai beban istishna tangguhan.

3. Beban istishna tangguhan diamortisasi secara proporsional sesuai dengan porsi pada pelunasan hutang istishna.

4. Jika terdapat barang pesanan yang terlambat untuk diserahkan karena kelalaian atau kesalahan penjual dan mengakibatkan kerugian pembeli, maka kerugian itu dikurangkan dari garansi penyelesaian proyek yang telah diserahkan penjual. Jika kerugian tersebut melebihi garansi penyelesaian proyek, maka selisihnya akan diakui sebagai piutang jatuh tempo kepada penjual dan jika 
diperlukan dibentuk penyisihan kerugian piutang.

5. Jika pembeli menolak menerima barang pesanan karena tidak sesuai dengan spesifikasi dan tidak memperoleh kembali seluruh jumlah uang yang telah dibayarkan kepada penjual, maka jumlah yang belum diperoleh kembali diakui sebagai piutang jatuh tempo kepada penjual dan jika diperlukan dibentuk pentisihan kerugian piutang.

6. Jika pembeli menerima barang pesanan yang tidak sesuai secara spesifikasi, maka barang pesanan dapat diukur dengan cara nilai yang lebih rendah antara nilai wajar dan biaya perolehan. Selisih yang terjadi dapat diakui sebagai kerugian pada periode berjalan

7. Dalam istishna paralel, jika pembeli menolak untuk menerima barang pesanan disebabkan tidak sesuainya dengan spesifikasi atas yang disepakati, maka barang pesanan dapat diukur dengan menggunakan nilai yang lebih rendah antara nilai wajar dan harga pokok istishna. Selisih yang terjadi dapat diakui sebagai kerugian atas periode berjalan.

\section{E. Akun Transaksi Pembiayaan Istishna Jurnal Standar Istishna Biasa-Akuntansi Penjual}

1. Pada saat pengeluaran biaya sebelum akad 


\begin{tabular}{|l|l|l|}
\hline $\begin{array}{l}\text { (Dr) Beban Istishna yang XX } \\
\text { ditangguhkan }\end{array}$ & \\
\hline (Cr) Kas & & XX \\
\hline
\end{tabular}

2. Jika terdapat akad tidak ditandatangani

\begin{tabular}{|l|r|r|}
\hline (Dr) Beban pra-akad & $\mathrm{XX}$ & \\
\hline $\begin{array}{l}\text { (Cr) Beban Istishna } \\
\text { yang ditangguhkan }\end{array}$ & $\mathrm{XX}$ \\
\hline
\end{tabular}

3. Pada Saat terjadi pengeluaran biaya istishna setelah akad ditandatangani

\begin{tabular}{|l|r|r|}
\hline Aktiva & XX & \\
Istishna dalam penyelesaian & & \\
\hline \begin{tabular}{l|r|r|}
$(\mathrm{Dr})$ Beban Istishna yang \\
ditangguhkan
\end{tabular} & $\mathrm{XX}$ & \\
\hline$(\mathrm{Cr})$ Kas & & $\mathrm{XX}$ \\
\hline
\end{tabular}

4. Pada saat penagihan kepada pembeli

\begin{tabular}{|l|r|r|}
\hline (Dr) Piutang Istishna & $X X$ & \\
\hline$(\mathrm{Cr})$ Termin Istishna & $\mathrm{XX}$ \\
\hline
\end{tabular}

5. Pada saat penerimaan pembayaran dari pembeli 


\begin{tabular}{|l|r|r|}
\hline (Dr) Kas & $X X$ & \\
\hline$(C r)$ Piutang Istishna & $X X$ \\
\hline
\end{tabular}

6. Pengakuan atas keuntungan yang dilakukan pada akhir periode dengan menggunakan metode persentase

\begin{tabular}{|l|r|r|}
\hline $\begin{array}{l}\text { (Dr) Beban pendapatan } \\
\text { Istishna }\end{array}$ & $\mathrm{XX}$ & \\
\hline $\begin{array}{l}\text { (Dr) Aktiva Istishna dalam } \\
\text { penyelesaian }\end{array}$ & $\mathrm{XX}$ & \\
\hline $\begin{array}{l}\text { (Cr) Pendapatan Istishna } \\
\text { (sesuai } \\
\text { porsi penyelesaian) }\end{array}$ & $\mathrm{XX}$ \\
\hline
\end{tabular}

7. Pengakuan kerugian pada akhir periode dengan menggunakan metode persentase

\begin{tabular}{|l|r|r|}
\hline $\begin{array}{l}\text { (Dr) Beban pendapatan } \\
\text { Istishna }\end{array}$ & XX \\
\hline $\begin{array}{l}\text { (Cr) Aktiva Istishna dalam } \\
\text { penyelesaian }\end{array}$ & \\
\hline $\begin{array}{l}\text { (Cr) Pendapatan Istishna } \\
\text { (sesuai porsi penyelesaian) }\end{array}$ & & \\
\hline
\end{tabular}


8. Pengakuan keuntungan/kerugian pada akhir periode dengan menggunakan metode akad selesai.

Maka,tidak ada jurnal, karena metode ini mengakui pendapatan istishna hanya pada akhir masa kontrak.

1. Pengakuan keuntungan pada akhir masa kontrak dengan menggunakan metode persentase.

\begin{tabular}{|l|l|l|}
\hline $\begin{array}{l}\text { (Dr) Beban pendapatan } \\
\text { Istishna }\end{array}$ & $\mathrm{XX}$ & \\
\hline $\begin{array}{l}\text { (Dr) Aktiva Istishna dalam } \\
\text { penyelesaian }\end{array}$ & $\mathrm{XX}$ & \\
\hline $\begin{array}{l}\text { (Cr) } \\
\text { Pendapatan Istishna(sesuai } \\
\text { porsi penyelesaian) }\end{array}$ & $\mathrm{XX}$ \\
\hline
\end{tabular}

2. Pengakuan kerugian pada akhir kontrak dengan menggunakan metode persentase.

\begin{tabular}{|l|r|r|}
\hline (Dr) Kerugian Istishna & $\mathrm{XX}$ & \\
\hline
\end{tabular}




\begin{tabular}{|l|l|}
\hline $\begin{array}{l}\text { (sebesar selisih antara } \\
\text { pendapatan dan beban } \\
\text { Istishna) }\end{array}$ & \\
\hline $\begin{array}{l}\text { (Cr) Aktiva Istishna dalam } \\
\text { penyelesaian }\end{array}$ & \\
\hline
\end{tabular}

3. Pengakuan keuntungan pada akhir masa kontrak dengan menggunakan metode akad selesai.

\begin{tabular}{|c|c|}
\hline $\begin{array}{l}\text { (Dr) Beban pendapatan } \\
\text { Istishna }\end{array}$ & $X X$ \\
\hline $\begin{array}{ll}(\mathrm{Dr}) & \text { Aktiva } \\
\text { Istishna } & \text { dalam } \\
\text { penyelesaian } & \end{array}$ & $X X$ \\
\hline $\begin{array}{ll}\mathrm{Cr}) & \text { Pendapatan } \\
\text { Istishna } & \end{array}$ & \\
\hline
\end{tabular}

4. Pengakuan kerugian pada akhir kontrak dengan menggunakan metode akad selesai.

\begin{tabular}{|l|l|l|}
\hline $\begin{array}{l}\text { (Dr) Kerugian Istishna } \\
\text { (sebesar selisih antara } \\
\text { pendapatan dan } \\
\text { beban Istishna) }\end{array}$ & \\
\hline
\end{tabular}


(Cr) Aktiva Istishna

dalam penyelesaian

5. Pada saat barang pesanan telah selesai diproduksi.

\begin{tabular}{|l|r|r|}
\hline $\begin{array}{l}\text { (Dr) Persediaan } \\
\text { Istishna }\end{array}$ & XX \\
\hline $\begin{array}{l}\text { (Cr) Aktiva Istishna } \\
\text { dalam penyelesaian }\end{array}$ & $\mathrm{XX}$ \\
\hline
\end{tabular}

6. Pada saat penjual menyerahkan atas barang pesanan kepada pembeli

\begin{tabular}{|l|r|r|}
\hline (Dr) Termin Istishna & $\mathrm{XX}$ & \\
\hline$(\mathrm{Cr})$ Persediaan Istishna & & $\mathrm{XX}$ \\
\hline
\end{tabular}


7. Pemberian potongan kepada pembeli

a) Potongan secara langsung

\begin{tabular}{|l|l|l|}
\hline (Dr) Pendapatan & $\mathrm{XX}$ & \\
Istishna & & \\
\hline (Cr) Piutang Istishna & $\mathrm{XX}$ \\
\hline
\end{tabular}

b) Potongan tidak langsung (reimbursed)

\begin{tabular}{|c|c|c|c|}
\hline $\begin{array}{l}\text { (Dr) Beban } \\
\text { (muqasah) }\end{array}$ & potongan & $X X$ & \\
\hline $\begin{array}{l}(\mathrm{Cr}) \quad \text { Kas } \\
\text { setelah } \\
\text { melunasi) }\end{array}$ & $\begin{array}{l}\text { (dibayar } \\
\text { pembeli }\end{array}$ & & $\mathrm{XX}$ \\
\hline
\end{tabular}

\section{Jurnal Standar Akuntansi Pembeli}

1. Saat pembeli menerima garansi penyelesaian proyek

Kas

$x x$

Titipan uang garansi

$x x$

2. Pembeli menerima tagihan dari penjual

Aktiva istishna dalam penyelesaian $x x$

Hutang istishna $\mathrm{XX}$

3. Pembeli membayar tagihan dari kontraktor

Hutang istishna

Kas $x x$

$x x$ 
4. Pembeli menerima aktiva istishna Persediaan $x x$ Aktiva istishna dalam penyelesaian $\quad \mathrm{xx}$

5. Pembeli menolak aktiva istishna dari sub-kontraktor akibat salah spesifikasi

Piutang kontraktor $\mathrm{XX}$ (sebesar uang yang belum kembali) Kas $\mathrm{XX}$ (sebesar uang yang telah kembali) Aktiva istishna dalam penyelesaian $\mathrm{XX}$

6. Pembeli menerima aktiva istishna meski salah spesifikasi

Persediaan $\quad x x$ (sebesar nilai istishna yang salah spesifikasi) Kerugian aktiva istishna $\quad \mathrm{xx}$ (sebesar penurunan nilai karena salah spesifikasi) Aktiva istishna dalam penyelesaian $\mathrm{XX}$

7. Bila kontraktor terlambat mengirim barang pesanan sehingga pembeli merugi

Uang garansi < kerugian

Titipan uang garansi $\mathrm{XX}$

Piutang kepada kontraktor $x x$

Pendapatan ganti rugi istishna $x x$ 


\section{Uang garansi > kerugian}

Titipan uang garansi $\quad x x$

Hutang kepada kontraktor $\quad x x$

Pendapatan ganti rugi istishna $\quad x x$

\section{F. Rangkuman}

Akad istishna' merupakan akad jual beli yang bentuk pemesanan barangnya sesuai dengan kriteria dan persyaratan tertentu yang disepakati antara pemesan dan penjual.

Istishna' dilakukan secara langsung antara pemesan dan penjual, atau dapat melalui perantara. Jika melalui perantara maka akad tersebut disebut dengan akad istishna' paralel.

Istishna' menurut para fuqaha adalah bentuk perkembangan dari akad salam dan telah diizinkan secara syariah islam. Untuk pengakuan pendapatan istishna' dapat dilakukan melalui akad langsung atau persentase penyelesaian. Persentase penyelesaian ini mirip dengan akuntansi konvensional, berbeda pada laba yaitu dipisahkan antara margin laba dan selisih nilai akad dengan nilai wajar.

\section{G. Studi Kasus Transaksi Pembiayaan Istishna}

PT Anugrah memerlukan rumah dengan tipe 120/216 untuk spesifikasi khusus kantor seharga Rp.200 juta. Uang muka yang dibayarkan oleh PT Anugrah sebesar Rp.50 juta. Perusahaan PT Anugrah 
mengajukan permohonan pembiayaan kepada Bank syariah mandiri. Ketika akad sudah ditandatangani antara kedua pihak dengan nilai nominal sebesar Rp. 200 juta, maka selanjutnya pihak bank syariah mandiri akan memesan kepada pihak pengembang dan pihak pengembang akan menyelesaikan pesanannya dengan jangka waktu 9 bulan. Bank syariah mandiri melakukan pembayaran pra akad senilai Rp. 1 juta dan selanjutnya akan dilakukan penandatanganan antara pihak bank dengan Pt Anugrah pada 1 Juni 2012. Pihak Perusahaan PT Anugrah akan menyerahkan uang muka senilai Rp. 50 juta dan pihak Bank syariah mandiri akan melakukan penandatanganan akad pembelian/pemesanan kepada pengembang pada 1 juni 2012 dengan harga beli Rp. 170 juta. Adapun data dan tagihan yang dilakukan oleh pihak pengembang hingga selesai per 1 februari 2013 antara lain :

2 Juni 2012 : penerimaan uang muka kepada bank syariah mandiri dari pihak pembeli

1 Juli 2012 : Penagihan untuk pembangunan aktiva istishna yang dilakukan oleh pengembang sebesar Rp. 30 juta

1 Okt 2012 :Penagihan untuk dilakukan pembangunan aktiva istishna oleh pengembang senilai Rp. 50 juta

1 Jan 2012 :Penagihan untuk dilakukannya pembangunan aktiva istishna oleh pengembang sebesar Rp. 90 juta 
1 Feb 2012 : penyerahan atas aktiva istishna yang sudah selesai oleh pihak pengembang kepada pihak bank syariah mandiri

1 Feb 2012 :Penyerahan atas aktiva istishna yang telah selesai oleh pihak pengembang kepada pihak bank syariah mandiri

PT Anuhrah melakukan anguran pembayaran rumah dalam jangka 2 tahun dan bank syariah mandiri menggunakan keuntungan istishna sebesar $10 \%$ atas pembiayaannya.

\section{Perhitungan:}

Pemesan akan melunasi rumah pesanannya pada saat rumah selesai dibangun dan diserahkan bank syariah kepada PT Amanah, dengan harrga kontrak 200 juta. Harga pokok rumah=Rp.170 juta. Jadi laba bank syariah=Rp200 juta - Rp.171 juta=Rp.29 juta. Harga jual bila diangsur 2 tahun= Rp.200 juta $+10 \%$ (Rp.200 juta)=Rp.220 juta. Angsuran/bulan= Rp.220 juta/24=Rp.9.166.667; - sedang margin/bulan = Rp. 20 juta/24=Rp.833.333;-

\section{Jurnal yang dibuat oleh bank syariah:}

1. Pada tanggal 1 juni 2012 bank syariah mandiri menerima uang muka dari perusahaan PT Anugrah

Dr. Kas

Cr. Uang Muka Istishna
Rp.50.000.000

Rp.50.000.000 
2. Transaksi biaya pembayaran pra akad yang dicatata oleh bank syariah mandiri sebesar Rp.1.000.000
Dr. Beban pra-akad yg tangguhan
Rp.1.000.000
Cr.Kas
Rp.1.000.000

3. Terjadinya kepastian atas akad istishna oleh pihak nasabah PT Anugrah
Dr. Aset istishna dalam penyelesaian
Rp.1.000.000
Cr. Beban pra akad tangguhan
Rp.1.000.000

4. Pada tanggal 1 Juli 2012 bank syariah mandiri memperoleh tagihan dari pihak pengembang dan harus dibayar sebesar Rp 30 juta

Dr. Aset Istishna dalam penyelesaian Rp.30.000.000

Cr. Hutang Istishna

Rp.30.000.000

5. Bank syariah mandiri melakukan pembayaran utang istishna
Dr. Hutang Istishna
Rp.30.000.000
Cr. Kas
Rp.30.000.000

6. Pada tanggal 1 Oktober 2012 dengan jumlah sebesar Rp.50 juta

Dr. Aset Istishna dalam penyelesaian Rp.50.000.000

Cr. Hutang Istishna Rp.50.000.000

7. Bank syariah mandiri melakukan pembayaran utang istishna

Dr. Hutang Istishna Rp.50.000.000 
8. Pada tanggal 1 Januari 2012 dengan jumlah Rp.90 juta
Dr. Aset Istishna dalam penyelesaian Rp.90.000.000
Cr. Hutang Istishna
Rp.90.000.000

9. Bank syariah mandiri melakukan pembayaran utang istishna
Dr. Hutang Istishna
Rp.90.000.000
Cr.Kas
Rp.90.000.000

10. Bank syariah mandiri menerima barang pesanan dari pihak pengembang yang sudah diselesaikan $100 \%$, maka jurnal yang dibuat oleh pihak bank adalah:
Dr. Aset Istishna
Rp.171.000.000
Cr. Aset Istishna dalam penyelesaian Rp171.000.000

11. Jurnal yang dibuat bank pada saat pihak bank syariah mandiri menyerahkan rumah tersebut kepada pihak nasabah PT Anugrah

Dr. Piutang Istishna

Rp.220.000.000

Cr. Persediaan barang istishna

$\mathrm{Rp} 171.000 .000$

Cr. Pendapatan margin istishna

Rp 29.000.000

Cr. Margin istishna tangguhan

Rp 20.000.000

Dr. Uang muka istishna

Rp.50.000.000

Cr. Piutang Istishna

Rp 50.000 .000

12. Penerimaan angsuran oleh bank syariah mandiri tiap bulan dari PT Anugrah

Dr. Ka/Rek PT Amanah

Rp.9.166.667

Cr. Piutang Istishna

Rp 9.166 .667 
Mengakui pendapatan margin istishna

Dr. Margin istishna tangguhan

Rp. 833.333

Cr. Pendapatan Margin Istishna

Rp 833.333 


\section{BAB VI \\ TEORI DAN PRAKTEK AKUNTANSI TRANSAKSI \\ MUDHARABAH}

\section{Kompetensi Dasar}

Setelah mempelajari bab ini, diharapkan membentuk mahasiswa yang kompeten dalam hal berikut :

1. Mampu melakukan pencatatan transaksi akuntansi dengan akad Mudharabah.

2. Pemahaman terhadap pengakuan dan pengukuran, penyajian serta pengungkapan akuntansi Mudharabah.

\section{Indikator}

Indikator yang ada dalam bab ini, sebagai berikut :

1. Kemampuan proses akuntansi untuk transaksi akad Mudharabah.

\section{Materi Pokok}

Materi utama pada bab ini adalah Akuntansi penyaluran dana dengan akad Mudharabah.

\section{A. Definisi Mudharabah}

Mudharabah berasal dari kata dharb, berarti memukul atau berjalan. Dalam hal ini, memukul atau 
berjalan merupakan proses seseorang memukulkan kakinya dalam menjalankan usahanya ${ }^{56}$.

Sedangkan Mudharabah secara terminologis merupakan bentuk kontrak (perjanjian) antara pemilik modal (rab al mal) dan pengguna dana (mudharib) dimana digunakan untuk aktivitas yang lebih produktif, dan hasil keuntungan dibagi antara pemodal dan pengelola dana. Apabila terjadi kerugian (jika ada) maka dapat ditanggung oleh pemilik modal, jika kerugian itu terjadi dalam keadaan normal pemodal tidak boleh intervensi kepada pengguna dana dalam menjalankan usahanya ${ }^{57}$.

Menurut PSAK 105 paragraf 4, Mudharabah merupakan akad kerjasama usaha antara dua pihak, dimana pihak pertama sebagai (pemilik dana) menyediakan seluruh dana, sedangkan pihak kedua sebagai (pengelola dana) bertindak selaku pengelola, serta keuntungan usaha dibagi sesuai kesepakatan dan apabila terjadi kerugian hanya ditanggung oleh pengelola dana ${ }^{58}$.

\footnotetext{
${ }^{56}$ Husnul Mawarid, "Analisis Penerapan Akuntansi Keuangan (SAK) Nomer 105 Tentang Pembiayaan Mudharabah Pada Laporan Keuangan Koperasi Jasa Keuangan Syariah Kalbar Madani Pontianak," Audit dan Akuntansi Fakultas Ekonomi Universitas

Tanjungpura 3, no. 2 (2014): 27-42.

57 Ibid.

58 Ibid.
} 


\section{B. Rukun Pembiayaan Mudharabah}

Rukun adalah segala sesuatu yang menyebabkan suatu akad dapat dilaksanakan, karena dalam rukun merupakan bagian yang tak terpisahkan sehingga dalam sebuah akad tidak akan batal dalam pelaksanaanya. Adapun rukun mudharabah menurut jumhur ulama yaitu

1. Terdapat sebuah pihak yang melakukan akad, diantaranya yaitu pemilik dana (Shahibul Maal) dan pengelola modal (Mudharib).

2. Adanya modal (Ra'sul Maal).

3. Usaha yang dijalankan (Al-'Amal).

4. Keuntungan (Ribh)

5. Terdapat ijab dan qobul (Sighat Akad)

Sedangkan dalam syarat mudharabah yang berkaitan dengan rukunnya, yaitu sebagai berikut : ${ }^{59}$

1. Dalam modal harus berupa barang atau uang yang dapat dinilai, diketahui jumlahnya, dan tunai tidak piutang.

2. Dalam keuntungan harus dibagi oleh kedua pihak, sedangkan besar keuntungan yang didapat harus disepakati diawal menjalin kontrak, apabila terjadi kerugian ditanggung oleh penyedia dana

\footnotetext{
59 Fransisca Yaningwati, "ANALISIS PENGARUH PEMBIAYAAN MUDHARABAH DAN MUSYARAKAH TERHADAP TINGKAT PROFITABILITAS ( RETURN ON EQUITY) ( Studi Pada Bank Umum Syariah Yang Terdaftar Di Bank Indonesia Periode 2009-2012)," jurnal administrasi Bisnis (JAB) 12, no. 1 (2014): 1-9.
} 


\section{Skema Pembiayaan Mudharabah}

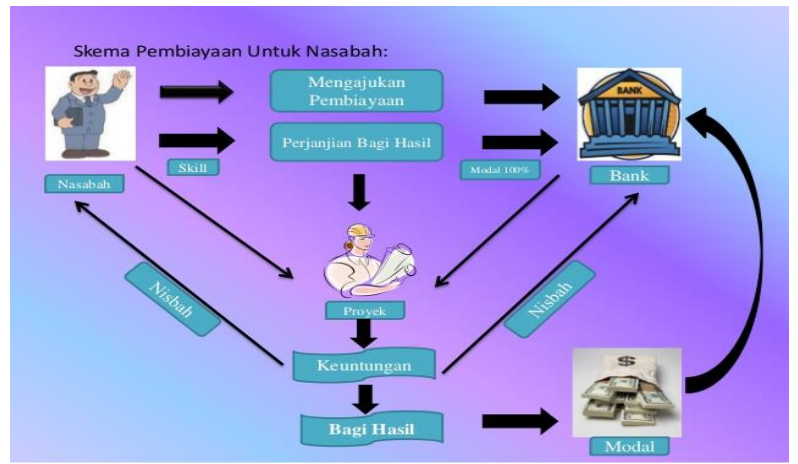

gambar 9.1 Skema Akad Mudharabah

Adapun skema pembiayaan mudharabah yaitu dapat diliat dari skema pembiayaan untuk nasabah sebagai berikut :

1. Hal pertama yaitu nasabah melakukan pengajuan pembiayaan kepada pihak bank guna memperoleh modal usaha.

2. Bank dapat memberikan modal sebesar $100 \%$ untuk dikelola oleh nasabah yang memiliki keahlian tersebut.

3. Terjalin sebuah akad, pada tahap ini ketika akad berlangsung telah ditentukan juga proporsi bagi hasilnya.

4. Apabila terjadi sebuah kerugian dalam menjalankan usaha dimana bukan kelalaian dari pihak nasabah, maka kerugian tersebut ditanggung oleh bank. 
5. Setelah proses usaha berjalan dengan lancar, maka keuntungan juga dibagi sesuai nisbah yang sudah ditentukan dan disepakati di awal kontrak. Dan pihak nasabah juga mengembalikan modal pokok kepada bank.

\section{Cakupan Akuntansi Pembiayaan Mudharabah}

Dalam cakupan ini diatur terkait akuntansi pemilik dana (shahibul maal) dan akuntansi sebagai pengelola dana (mudharib). Pada penghimpunan dana yang dilakukan oleh sebuah lembaga keuangan syariah (LKS), hal ini pihak nasabah sebagai pemodal (shahibul maal) sedangkan LKS sebagai pengelola (mudharib) maka, bisa disebut nasabah sebagai penyedia dana yang menggunakan "akuntansi pemilik dana" dan LKS sebagai pengelola dana dengan menerapkan "akuntansi pengelola dana" pada PSAK No. 105 tentang akuntansi Mudharabah. Sedangkan pada penyaluran dana yang dilakukan oleh lembaga keuangan syariah (LKS), hal ini yang menjadi pemilik dana/pemodal (shahibul maal) adalah pihak LKS, sedangkan sebagai pengelola dana adalah pihak nasabah (mudharib) atau sering disebut dengan debitur. (Wiroso, 2011).

\section{E. Akun Transaksi Pembiayaan Mudharabah}

1. Pengakuan dan Pengukuran Pembiayaan Mudharabah (Muthaher, 2012) 
Dalam proses pengakuan dan pengukuran pada pembiayaan mudharabah, sudah dijelaskan pada PSAK 105 tentang akuntansi perbankan syariah, ialah

a. Pengakuan pembiayaan mudharabah adalah sebagai berikut :

1) Pembiayaan mudharabah dapat diakui, apabila dalam proses pembayaran kas atau penyerahan asset nonkas kepada pihak pengelola dana (mudharib).

2) Selanjutnya pembiayaan mudharabah yang diberikan secara bertahap dapat diakui pada saat pembayaran atau penyerahan.

b. Pengukuran dalam proses pembiayaan mudharabah sebagai berikut :

1) Pembiayaan mudharabah dalam bentuk kas dapat diukur dengan sejumlah uang yang sudah diberikan kepada pihak bank pada saat melakukan proses pembayaran, adapun jurnalnya yaitu :

Db. Pembiayaan Mudharabah $\quad x x x x$ Kr. Kas $x x x$

2) Pembiayaan mudharabah dalam bentuk asset nonkas :

a) Apabila nilai wajar aset yang diserahkan lebih rendah dibandingkan nilai buku maka jurnalnya :

Db. Pembiayaan Mudharabah $\quad$ xxxx

Db. Kerugian Penyerahan Aset $x x x x$ 
b) Apabila nilai wajar aset yang diserahkan lebih tinggi dari nilai buku:

Db. Pembiayaan Mudharabah $x x x x$

Kr. Aset Nonkas

$x x x x$

Kr. Keuntungan Penyerahan Aset $\quad x x x x$

c. Beban yang terjadi sehubungan dengan akad mudharabah masih belum bisa diakui dalam bagian pembiayaan mudharabah terkecuali telah disepakati bersama.

1) Proses pengeluaran biaya dalam rangka akad mudharabah

Db. Uang Muka Mudharabah xxxx

Kr. Kas/Kliring $\mathrm{XXXX}$

2) Jika diliat dari kesepakatan dapat diakui sebagai pembiayaan mudharabah Db. Biaya Akad Mudharabah $\quad$ xxxx Kr. Uang Muka Mudharabah $\operatorname{XXXX}$

Apabila ketika akad belangsung, sebelum dimulainya usaha tetapi sebagian pembiayaan mudharabah hilang karena adanya kerusakan/sebab lain tidak ada unsur kelalaian dari pihak mudharib, maka kerugian tersebut tidak mengurangi saldo pembiayaan mudharabah dan diakui sebagai kerugian bank. Adapun jurnlanya yaitu :

Db. Kerugian Pembiayaan Mudharabah xxxx 
Kr. Pembiayaan Mudharabah

XXXX

2. Pengakuan Laba atau Rugi Mudharabah (Muthaher, 2012)

a. Apabila dalam pembiayaan mudharabah terjadi kerugian dikarenakan terjadi kerusakan atau sebab lainya, tetapi bukan kelalaian dari pihak mudharib maka dalam hal ini pihak bank yang telah menanggung kerugian pembiayan mudharabah tersebut. Adapun jurnalnya yaitu

Db. Kerugian Pembiayaan Mudharabah xxxx Kr. Pembiayaan Mudharabah

XXXX

b. Sedangkan pada saat terjalin akad mudharabah diakhiri sebelum jatuh tempo atau pada saat jatuh tempo sedangkan pembiayaan mudharabah belum dibayar oleh pihak mudharib, maka pembiayaan mudharabah dapat diakui sebagai piutang jatuh tempo. Jurnalnya yaitu :

Db. Pembiayaan Mudharabah Piutang xxxx Jatuh Tempo

Kr. Pembiayaan Mudharabah

XXXX

c. Penerimaan Keuntungan Mudharabah

Db. Kas/Rekening

XXXX 
Kr. Pendapatan Bagi Hasil Mudharabah

XXXX

d. Proses pencatatan apabila terjadi kerugian mudharabah dimana yang telah melewati satu periode pelaporan

Db. Kerugian Pembiayaan Mudharabah $\quad$ xxxx

Kr. Pembiayaan Mudharabah

XXXX

e. Proses pencatatan kerugian dimana yang timbul akibat kelalaian atau kesalahan dari pihak mudharib

Db. Pembiayaan Mudharabah-Piutang $\quad x x x x$ Jatuh Tempo

Kr. Pembiayaan Mudharabah

XXXX

f. Pelunasan pembiayaan mudharabah sebelum atau saat akad jatuh tempo

Db. Kas/Rekening

$X X X X$

Kr. Pembiayaan Mudharabah

$X X X$

\section{Contoh Ilustrasi:}

Tanggal 1 Agustus 20XA Bank Sejahtera Syariah (BSS) menyetujui pemberian fasilitas mudharabah Muthlaqah PT Mawar Putih yang bergerak di bidang SPBU dengan kesepakatan sebagai berikut.

Plafon : Rp1.450.000.000 
Objek bagi hasil : Pendapatan (gross profit sharing)

Nisbah : 70\% PT Haniya dan 30\% BMS

Jangka Waktu : 10 bulan (jatuh tempo tanggal 10 Juni 20XB)

Biaya administrasi : Rp14.500.000 (dibayar saat akad ditandatangani)

Pelunasan : Pengembalian pokok di akhir periode.

Keterangan : Modal dari BSS diberikan secara tunai tanggal 10 Agustus 20XA. Pelaporan dan pembayaran bagi hasil oleh nasabah dilakukan setiap tanggal 10 mulai bulan September

\section{Saat Penandatanganan Akad Mudharabah}

Jurnal pada tanggal 1 Agustus / pada saat akad mudharabah ditandatangani terdiri atas jurnal pembukaan rekening administratif komitmen pembiayaan PT Mawar Putih dan jurnal pembebanan biaya administrasi.

\begin{tabular}{|l|l|c|c|}
\hline Tgl & Rekening & Debit (Rp) & Kredit (Rp) \\
\hline $01 /$ & $\begin{array}{l}\text { Db. Pos lawan komitmen } \\
\text { administratif pembiayaan }\end{array}$ & 1.450 .000 .000 & \\
\hline
\end{tabular}




\begin{tabular}{|l|l|l|l|}
\hline XA & $\begin{array}{l}\text { Kr. Kewajiban komitmen } \\
\text { administratif pembiayaan }\end{array}$ & $\begin{array}{c}1.450 .000 . \\
000\end{array}$ \\
\hline $\begin{array}{l}\text { (izin tarik tanggal 10 Agustus } \\
\text { sebesar 1.450.000.000) }\end{array}$ & & \\
\hline & $\begin{array}{l}\text { Db. Kas/Rekening nasabah - PT } \\
\text { Haniya }\end{array}$ & 14.500 .000 & \\
\hline Kr. Pendapatan administrasi & & 14.500 .000 \\
\hline
\end{tabular}

\section{Penyerahan Pembiayaan Mudharabah}

Berdasarkan PSAK 105 paragraf 12, disebutkan bahwasannya dana mudharabah yang disalurkan oleh pemilik dana diakui sebagai pembiayaan mudharabah pada saat pembayaran kas atau penyerahan aset non-kas kepada pengelola dana.

Misalkan tanggal 10 Agustus 20XA, BSS mencairkan pembiayaan sebesar Rp1.450.000.000 untuk pembiayaan mudharabah.

\begin{tabular}{|l|l|l|l|}
\hline Tanggal & Rekening & Debit (Rp) & Kredit (Rp) \\
\hline 05/10/XA & Db. Pembiayaan mudharabah* & 1.450 .000 .000 & \\
\hline & Kr. Kas/Rekening nasabah & & 1.450 .000 .000 \\
\hline
\end{tabular}




\begin{tabular}{|l|l|l|l|}
\hline & & & \\
\hline $05 / 10 / X A$ & $\begin{array}{l}\text { Db. Kewajiban komitmen } \\
\text { administratif Pembiayaan }\end{array}$ & 1.450 .000 .000 & \\
\hline & $\begin{array}{l}\text { Kr. Pos lawan komitmen } \\
\text { administratif pembiayaan }\end{array}$ & 1.450 .000 .000 \\
\hline
\end{tabular}

\section{Penerimaan Bagi Hasil Mudharabah Berdasarkan PSAK 105} paragraf 22, dinyatakan bahwa pengakuan penghasilan usaha mudharabah dalam praktik dapat diketahui berdasarkan laporan bagi hasil atas realisasi penghasilan usaha dari pengelola dana dan tidak diperkenankan mengakui pendapatan dari proyeksi hasil usaha. Sekiranya bagian hasil usaha belum dibayar oleh pengelola, bagian tersebut diakui sebagai piutang (PSAK 105 paragraf 24).

Berikut adalah realisasi laba bruto PT Mawar Putih selama 10 bulan yang dilaporkan setiap tanggal 10 bulan berikutnya.

\begin{tabular}{|l|l|l|l|l|l|}
\hline No. & Bulan & $\begin{array}{l}\text { Jumlah Laba } \\
\text { Bruto (Rp) }\end{array}$ & $\begin{array}{l}\text { Porsi Bank } \\
\mathbf{3 0 \%}(\mathbf{R p})\end{array}$ & $\begin{array}{l}\text { Tanggal } \\
\text { Pelaporan Bagi } \\
\text { Hasil }\end{array}$ & $\begin{array}{l}\text { Tanggal } \\
\text { Pembayaran } \\
\text { Bagi Hasil }\end{array}$ \\
\hline 1. & Ags XA & 20.000 .000 & 6.000 .000 & $10 \mathrm{Sep}$ & $10 \mathrm{Sep}$ \\
\hline 2. & Sep XA & 50.000 .000 & 15.000 .000 & $10 \mathrm{Okt}$ & $10 \mathrm{Okt}$ \\
\hline 3. & Okt XA & 45.000 .000 & 13.500 .000 & $10 \mathrm{Nov}$ & $10 \mathrm{Nov}$ \\
\hline
\end{tabular}




\begin{tabular}{|l|l|l|l|l|l|}
\hline 4. & Nov XA & 40.000 .000 & 12.000 .000 & $10 \mathrm{Des}$ & 10 Des \\
\hline 5. & Des XA & 60.000 .000 & 18.000 .000 & $10 \mathrm{Jan}$ & 10 Jan \\
\hline 6. & Jan XB & 50.000 .000 & 15.000 .000 & $10 \mathrm{Feb}$ & $10 \mathrm{Feb}$ \\
\hline 7. & Feb XB & 40.000 .000 & 12.000 .000 & $10 \mathrm{Mar}$ & $10 \mathrm{Mar}$ \\
\hline 8. & Mar XB & 50.000 .000 & 15.000 .000 & $10 \mathrm{Apr}$ & $10 \mathrm{Apr}$ \\
\hline 9. & Apr XB & 55.000 .000 & 16.500 .000 & $10 \mathrm{Mei}$ & 05 Jun \\
\hline 10. & Mei XB & 60.000 .000 & 18.000 .000 & $15 \mathrm{Jun}$ & 15 Jun \\
\hline
\end{tabular}

Transaksi di atas dapat diklasifikasikan dalam dua bentuk, yaitu sebagai:

1. Penerimaan bagi hasil yang pembayarannya dilakukan bersamaan dengan pelaporan bagi hasil, seperti bagi hasil untuk bulan Agustus, September, Oktober, November, Desember, Januari, Februari, Maret. Bentuk transaksinya adalah sebagai berikut:

2. Penerimaan bagi hasil yang waktu pembayarannya

\begin{tabular}{|c|l|c|c|}
\hline $\begin{array}{c}\text { Tang } \\
\text { gal }\end{array}$ & Rekening & Debit (Rp) & Kredit (Rp) \\
\hline $\begin{array}{c}\text { 10/09 } \\
\text { /XA }\end{array}$ & Db. Kas/Rekening nasabah & 6.000 .000 & \\
\hline
\end{tabular}

berbeda dengan tanggal pelaporan bagi hasil seperti 


\begin{tabular}{|c|c|c|c|}
\hline & $\begin{array}{l}\text { Kr. Pendapatan bagi } \\
\text { hasil mudharabah }\end{array}$ & & 6.000 .000 \\
\hline \multirow{2}{*}{$\begin{array}{c}10 / 10 \\
/ X A\end{array}$} & Db. Kas/Rekening nasabah & 15.000 .000 & \\
\hline & $\begin{array}{l}\text { Kr. Pendapatan bagi } \\
\text { hasil mudharabah }\end{array}$ & & 15.000 .000 \\
\hline \multirow{2}{*}{$\begin{array}{c}10 / 11 \\
/ X A\end{array}$} & Db. Kas/Rekening nasabah & 13.500 .000 & \\
\hline & $\begin{array}{l}\text { Kr. Pendapatan bagi } \\
\text { hasil mudharabah }\end{array}$ & & 13.500 .000 \\
\hline \multirow{2}{*}{$\begin{array}{c}10 / 12 \\
/ X B\end{array}$} & Db. Kas/Rekening nasabah & 12.000 .000 & \\
\hline & $\begin{array}{l}\text { Kr. Pendapatan bagi } \\
\text { hasil mudharabah }\end{array}$ & & 12.000 .000 \\
\hline \multirow{2}{*}{$\begin{array}{c}10 / 01 \\
/ \mathrm{XB}\end{array}$} & Db. Kas/Rekening nasabah & 18.000 .000 & \\
\hline & $\begin{array}{r}\text { Kr. Pendapatan bagi } \\
\text { hasil mudharabah }\end{array}$ & & 18.000 .000 \\
\hline \multirow{2}{*}{$\begin{array}{c}10 / 02 \\
/ \mathrm{XB}\end{array}$} & Db. Kas/Rekening nasabah & 15.000 .000 & \\
\hline & $\begin{array}{l}\text { Kr. Pendapatan bagi } \\
\text { hasil mudharabah }\end{array}$ & & 15.000 .000 \\
\hline \multirow{3}{*}{$\begin{array}{c}10 / 02 \\
/ X B\end{array}$} & Db. Kas/Rekening nasabah & 12.000 .000 & \\
\hline & & & \\
\hline & $\begin{array}{l}\text { Kr. Pendapatan bagi } \\
\text { hasil mudharabah }\end{array}$ & & 12.000 .000 \\
\hline
\end{tabular}




\begin{tabular}{|c|c|c|c|}
\hline $\begin{array}{c}\text { 10/04 } \\
\text { /XB }\end{array}$ & Db. Kas/Rekening nasabah & 15.000 .000 & \\
\hline & $\begin{array}{c}\text { Kr. Pendapatan bagi } \\
\text { hasil mudharabah }\end{array}$ & 15.000 .000 \\
\hline
\end{tabular}

pada bagi hasil bulan April dan Mei. Berdasarkan PSAK 105 paragraf 24, disebutkan bahwasannya bagian hasil usaha yang belum dibayar oleh pengelola, maka bagian tersebut diakui sebagai piutang. Bentuk transaksinya sebagai berikut:

\begin{tabular}{|l|l|l|l|}
\hline $\begin{array}{l}\text { Tang } \\
\text { gal }\end{array}$ & Rekening & Debit (Rp) & Kredit (Rp) \\
\hline $\begin{array}{l}10 / 0 \\
5 / \mathrm{XB}\end{array}$ & $\begin{array}{l}\text { Db. Piutang pendapatan bagi } \\
\text { hasil mudharabah }\end{array}$ & 16.500 .000 & \\
\hline & $\begin{array}{l}\text { Kr. Pendapatan bagi hasil } \\
\text { mudharabah } \\
\text { akrual }\end{array}$ & 16.500 .000 \\
\hline $6 /$ XB & $\begin{array}{l}\text { Db. Kas/rekening nasabah } \\
\text { Kr. Piutang pendapatan bagi } \\
\text { hasil mudharabah }\end{array}$ & 16.500 .000 & 16.500 .000 \\
\hline $\begin{array}{l}\text { Db. Pendapatan bagi hasil } \\
\text { mudharabah - akrual }\end{array}$ & 16.500 .000 & \\
\hline $\begin{array}{l}\text { Kr. Pendapatan bagi hasil } \\
\text { mudharabah }\end{array}$ & & 16.500 .000 \\
\hline
\end{tabular}




\begin{tabular}{|c|c|c|c|}
\hline $\begin{array}{l}10 / 0 \\
6 / X B\end{array}$ & $\begin{array}{l}\text { Db. Piutang pendapatan bagi } \\
\text { hasil mudharabah }\end{array}$ & 18.000 .000 & \\
\hline & $\begin{array}{l}\text { Kr. Pendapatan bagi hasil } \\
\text { mudharabah - akrual }\end{array}$ & & 18.000 .000 \\
\hline \multirow{4}{*}{$\begin{array}{l}15 / 0 \\
6 / X B\end{array}$} & Db. Kas/rekening nasabah & 18.000 .000 & \\
\hline & $\begin{array}{l}\text { Kr. Piutang pendapatan bagi } \\
\text { hasil mudharabah }\end{array}$ & & 18.000 .000 \\
\hline & $\begin{array}{l}\text { Db. Pendapatan bagi hasil } \\
\text { mudharabah - akrual }\end{array}$ & 18.000 .000 & \\
\hline & $\begin{array}{l}\text { Kr. Pendapatan bagi hasil } \\
\text { mudharabah }\end{array}$ & & 18.000 .000 \\
\hline
\end{tabular}

\section{Saat Akad Berakhir}

\section{Cara 1: nasabah pembiayaan mampu}

mengembalikan modal mudharabah. Misalkan pada tanggal 10 Juni 20XB, saat jatuh tempo, PT Mawar

Putih melunasi pembiayaan mudharabah sebesar Rp1.450.000.000. Maka, jurnal transaksi tersebut sebagai berikut:

\begin{tabular}{|c|l|r|r|}
\hline Tgl & Rekening & Debit (Rp) & Kredit (Rp) \\
\hline $10 / 0$ & Db. kas/Rekening & 1.450 .000 .000 & \\
\hline
\end{tabular}




\begin{tabular}{|l|l|l|l|}
\hline $6 / X \mathrm{~B}$ & nasabah & & \\
\hline & $\begin{array}{l}\text { Kr. Pembiayaan } \\
\text { mudharabah }\end{array}$ & 1.450 .000 .000 \\
\hline
\end{tabular}

Cara 2: Ketika nasabah tidak mampu mengembalikan modal mudharabah.Berdasarkan PSAK 105 paragraf 19, disebutkan bahwa jika akad mudharabah berakhir sebelum atau saat akad jatuh tempo dan belum dibayar oleh pengelola dana, maka pembiayaan mudharabah diakui sebagai piutang.

Contoh, pada tanggal 10 Juni 20XB, saat jatuh tempo, PT Mawar Putih tidak mampu melunasi pembiayaan mudharabah, maka jurnal pada saat jatuh tempo tersebut sebagai berikut:

\begin{tabular}{|c|l|l|}
\hline Rekening & Debit (Rp) & Kredit (Rp) \\
\hline $\begin{array}{l}\text { Db Piutang pembiayaan mudharabah jatuh } \\
\text { tempo }\end{array}$ & 1.450 .000 .000 & \\
\hline Kr. Pembiayaan mudharabah & & 1.450 .000 .000 \\
\hline
\end{tabular}

\section{F. Rangkuman}

Akad Mudharabah adalah perjanjian yang dilakukan antara dua pihak yaitu shahibul maal (pemilik dana) dan mudharib (pengusaha). Pemilik dana mengamanahkan 
modal atau uangnya kepada pengelola (pengusaha) untuk menjalankan suatu usaha. Sedangkan pengelola ikut serta dalam tenaga, waktu dan keterampilan dalam mengelola usaha tersebut sesuai dengan isi akad. Apabila berlangsungnya usaha mengalami keuntungan maka dibagi sesuai porsi nisbah yang telah ditentukan di awal akad dan apabila terjadi kerugian maka ditanggung oleh pemilik dana (shahibul maal) tetapi kerugian itu tidak ada unsur kelalaian pengeloal (mudharib).

Alur transaksi pembiayaan mudharabah sebagai berikut

1. Nasabah melakukan pengajuan pembiayaan kepada pihak bank untuk mendapatkan bantuan modal usaha.

2. Bank dapat memberikan modal sebesar $100 \%$ untuk dikelola oleh nasabah yang memiliki keahlian tersebut.

3. Dilakukannya akad dan menentukan proporsi bagi hasil.

4. Setelah proses usaha berjalan dengan lancar, maka keuntungan dibagi sesuai nisbah yang sudah ditentukan dan disepakati di awal kontrak. Dan pihak nasabah juga mengembalikan modal pokok kepada bank, 
jika mengalami kerugian maka yang menanggung pihak pemodal.

\section{G. Studi Kasus Transaksi Pembiayaan Mudharabah}

SOAL-SOAL LATIHAN:

\section{A. Soal Teori}

1. Jelaskanlah definisi mudharabah!

2. Jelaskanlah perbedaan antara mudharabah muthlaqah, mudharabah muqayyadah dan mudharabah musytarakah!

3. Dalam kondisi apakah masing-masing mudharabah muthalaqah, mudharabah muqayyadah dan mudharabah musytarakah cocok diterapkan?

4. Apakah landasan syar'i dibolehkannya transaksi mudharabah?

5. Jelaskanlah rukun transaksi mudharabah.

\section{B. Soal Kasus}

Pada tanggal 5 Januari 20XA ditandatangani akad pembiayaan mudharabah antara BPRS Minang Raya dengan PT. Ufi Widi, senilai Rp. 100.000.000 untuk pembiayaan proyek renovasi 2 unit puskesmas dari Pemerintah Kota Padang. Bagi hasil usaha didasarkan atas laba bruto proyek dengan komposisi $25 \%$ untuk BPRS. Buatlah jurnal untuk rangkaian transaksi berikut: 
1. Tanggal 5 Januari BPRS Minang Raya membuka rekening komitmen administratif pembiayaan tersebut.

2. Tanggal 5 Januari BPRS membebankan biaya administrasi pembiayaan kepada PT Ufi Widi sebesar 0,2 \% dari nilai pembiayaan. Pembebanan langsung dilakukan dengan mendebit rekening PT. Ufi Widi

3. Tanggal 10 Januari 20XA, BPRS mencairkan pembiayaan sebesar $\mathrm{Rp}$ 100.000.000 untuk investasi mudharabah pada proyek renovasi Puskesmas yang dikelola oleh PT Ufi Widi.

4. Tanggal 10 Maret 20XA PT Ufi Widi melaporkan telah menerima uang proyek dari pemerintah untuk puskesmas pertama dengan laba kotor sebesar Rp 20.000.000, bagi hasil untuk BPRS (25\%) langsung diserahkan secara tunai pada tanggal yang sama.

5. Tanggal 20 April 20XA PT Ufi Widi melaporkan telah menerima uang proyek dari pemerintah untuk puskesmas kedua dengan laba kotor sebesar Rp 16.000.000, bagi hasil untuk BPRS (25\%) dibayarkan secara tunai pada tanggal 27 April 20XA. 
6. Tanggal 10 Mei 20XA, saat jatuh tempo PT. Ufi Widi melunasi investasi mudharabah secara tunai sebesar $\mathrm{Rp}$ 100.000.000. 


\section{BAB VII}

\section{TEORI DAN PRAKTEK AKUNTANSI TRANSAKSI MUSYARAKAH}

\section{Kompetensi Dasar}

Setelah mempelajari bab ini, diharapkan membentuk mahasiswa yang kompeten dalam hal berikut :

1. Mampu melakukan pencatatan transaksi akuntansi dengan akad Musyarakah.

2. Pemahaman terhadap pengakuan dan pengukuran, penyajian serta pengungkapan akuntansi Musyarakah.

\section{Indikator}

Indikator yang ada dalam bab ini, sebagai berikut :

1. Kemampuan proses akuntansi untuk transaksi akad Musyarakah.

\section{Materi Pokok}

Materi utama pada bab ini adalah Akuntansi penyaluran dana dengan akad Musyarakah. 


\section{A. Pengertian Musyarakah}

Dalam bahasa arab musyarakah berarti pencampuran, serikat atau penggabungan. Maksud dalam arti tersebut merupakan penggabungan antara modal satu dengan modal pihak lain yang tidak dapat terpisahkan satu sama lain. Sedangkan syirkah dalam bahasa arab yaitu penggabungan antara dua bagian atau lebih yang tidak dapat dibedakan dalam setiap bagiannya ${ }^{60}$.

Dalam akuntansi musyarakah merupakan salah satu akad kerja sama yang dilakukan antara kedua belah pihak atau lebih yang bertujuan untuk menjalankan suatu usaha tertentu dengan melihat kondis setiap masingmasing pihak dan memberikan kontribusi dananya, jika mendapatkan keuntungan maka akan dibagi secara rata, sedangkan bila terjadi kerugian maka akan ditanggung sesuai pada porsi kontribusi dana tersebut ${ }^{61}$. Adapun Pengertian musyarakah atau syirkah menurut pendapat para ulama adalah sebagai berikut:

1. Menurut pendapat hanafiah, syirkah merupakan suatu perjanjian dalam akad yang dilakukan antara dua orang dengan menyerahkan masing-masing modal dan akan mendaptkan keuntungan.

${ }^{60}$ Muammar Khaddafi, Akuntansi Syariah : Meletakkan Nilai-Nilai Syariah Islam Dalam Ilmu Akuntansi, ed. by Arfan Ikhsan, Cetakan 1 (Medan: Madenatera, 2016), hlm 242-243.

${ }^{61}$ PSAK and 106, Pedoman Standar Akuntansi Perbankan Syariah (Jakarta: Ikatan Akuntansi Indonesia, 2007). 
2. Menurut pendapat malikiyah, syirkah merupakan suatu persetujuan yang dilakukan untuk tasarruf dari kedua orang yaitu memberikan persetujuan untuk orang yang melakukan serikat kepada teman serikatnya dalam hal melakukan tasarruf dari setiap harta antara keduanya yang memiliki tasarruf dari berbagai masing-masing peserta tersebut.

3. Menurut pendapat syafi'iyah, syirkah merupakah sesuatu yang dipergunakan atas hak dari suatu barang yang ditetapkan terhadap dua orang atau lebih dengan menjalankannya secara bersamaan.

4. Syirkah dalam kamus Al-Mu'jam Al-Wasith yang merupakan salah satu akad dalam perjanjian yang dilakukan dengan dua pihak atau lebih yang bertujuan untuk menjalankannya secara bersamasama.

Dalam hal ini, landasan hukum yang menjelaskan tentang musyarakah adalah sebagai berikut : QS.An-Nisa : 12

Artinya : "Dan jika saudara-saudara itu lebih dua orang, maka mereka bersyarikat pada yang sepertiga itu".

QS. As-Shaad : 24

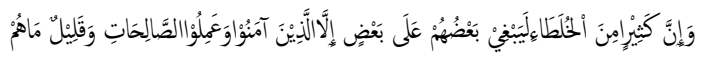


Artinya : "Dan sesungguhnya kebanyakan dari orangorang yang berserikat itu sebagian mereka berbuat zalim kepada sebagian yang lain, kecuali orang-orang yang beriman dan mengerjakan amal-amal shaleh dan amat sedikit ini".

\section{Al-Hadits}

Selain ayat dalam Al-Qur'an yang menjelaskan tentang pembiayaan musyarakah, dalam hadits qudsi pun sudah dijelaskan bahwa Rasulullah SAW bersabdah yang membolehkan untuk melakukan transaksi akad syirkah dengan mengatakan :

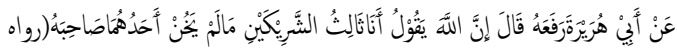

$$
\begin{aligned}
& \text { أبوادودوالماك عن أبي هريرة) }
\end{aligned}
$$

Artinya: Dari Abu Hurairah, Rasulullah SAW, bersabdah,"Sesungguhnya Allah Azza Wa Jalla berfirman, Aku pihak ketiga dari dua orang yang berserikat selama salah satunya tidak mengkhianati lainnya". (HR. Abu Dawud no. 2936, dalam kitab al-Buyu dan hakim).

\section{B. Rukun Pembiayaan Musyarakah}

Dalam melakukan pembiayaan musyarakah adapun ketentuan harus memenuhi rukun, agar akad tersebut bisa dikatakan sah secara syariah. Adapun rukun dalam pembiayaan musyarakah adalah sebagai berikut ${ }^{62}$ :

62 Abdul Ghofur Anshori, Perbankan Syariah Di Indonesia (Yogyakarta: Gadjah Mada University Press, 2018), hal 128-130. 
1. Orang yang berakad

Merupakan suatu akad kontrak dalam pelaksanaan perjanjian yang dilakukan antara kedua belah pihak yang mempunyai kepentingan dalam menjalankan usaha tersebut dengan melakukan kerjasama. Dalam hal ini, masing-masing pihak harus menyediakan modal dan pekerjaan, dan setiap pihak harus dapat mengatur modalnya yang sedang dijalankan dalam pelaksanaan bisnis akad musyarakah tersebut. Dalam menjalankan bisnis musyarakah setiap orang diberi wewenang, ada yang mengelola aset dan ada yang mengawasi supaya tidak ada kejadian atau kesalahan dalam menjalankan bisnis tersebut. Selain itu dalam menjalankan bisnis musyarakat setiap masingmasing pihak dilarang mencairkan dananya untuk kebutuhan pribadi.

2. Obyek dalam berakad

a. Modal

Dalam menjalankan akad musyarakat modal harus diberikan secara tunai baik berupa uang, emas, maupun perak. Modal yang berikan dalam aset dapat berupa barang, peralatan, properti dan yang lainnya, dalam pemberian modal tersebut jika dilihat dengan nilai uang secara tunai maka akan sebanding dan harus dapat disepakati antara kedua pihak.

b. Kerja 
Dalam bisnis kerjasama antara kedua belah pihak harus terlibat keduanya untuk menjalankan pekerjaan musyarakah dan tidak diperbolehkan salah satu diantara mereka tidak mau ikut campur dalam pelaksanaan bisnis musyarakah tersebut, hal ini merupakan salah satu dari dasar hukum islam.

\section{c. Keuntungan}

Dalam pelaksanaan bisnis musyarakah jika mendapatkan keuntungan atau kerugian maka harus dijelaskan secara terbuka tanpa ada yang ditutupi. Hal ini dikarenakan, agar kedua belah pihak saling mengerti satu sama lain dan tidak menimbulkan kesalah pahaman. Jika mendapatkan keuntungan maka harus dibagi secara rata sesuai dengan sistem pembagian pada akad tersebut dan jika mendapatkan kerugian maka harus dibagi sesuai dengan proporsional masing-masing saham yang sudah diberikan kepada setiap pihak. Namun jika terdapat biaya operasional yang harus dibayarkan maka, pembayaran biaya tersebut harus ditanggung bersama oleh kedua belah pihak sesuai dengan kesepakatan.

3. ljab qabul

Dalam menjalankan kontrak perjanjian kerjasama supaya dapat dikatakan sah, harus adanya kesepakatan antara kedua pihak melalui ucapaan bahwa siap menjalankan akad musyarakah. 
Perjanjian kontrak kerjasama sebaiknya harus sesuai dengan akad yang sudah tertulis dan harus menggunakan pihak notaris agar dapat mengantisipasi terjadinya kesalah pahaman dimasa yang akan datang.

\section{Skema Pembiayaan Musyarakah}

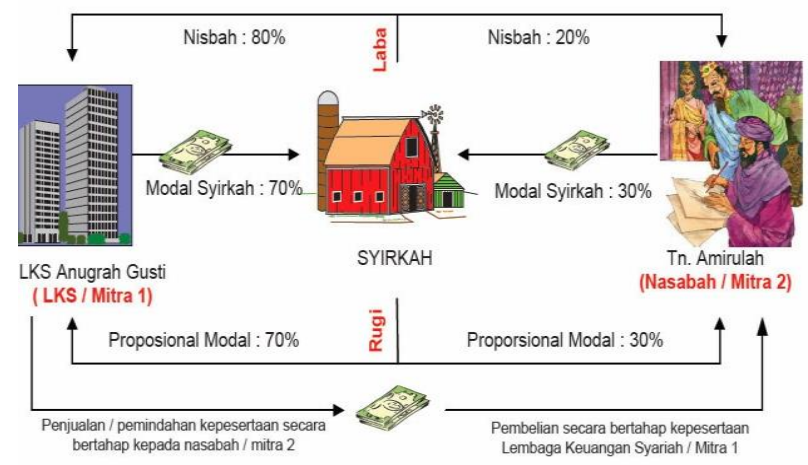

Gambar 1. Skema Pembiayaan Musyarakah

Pada transaksi pembiayaan musyarakah adapun penjelasan alur yang dapat dilihat pada ilustrasi gambar diatas adalah ${ }^{63}$ :

1. Dalam skema proyek diatas dapat dijelaskan sesuai dengan kesepakatan kedua pihak, bahwa, Lembaga Keuangan Syariah Anugrah Gusti sebagai pihak mitra

${ }^{63}$ Wiroso, Produk Perbankan Syariah, Cetakan 1 (Jakarta: LPFE Usakti, 2011), hal 299-230. 
1 akan menyerahkan modalnya dari nilai proyek sebesar 70\% dan pihak mitra ke 2 sebagai nasabah yang bernama Tuan Amirulah akan menyerahkan modalnya dari nilai proyek sebesar $30 \%$. Dalam prinsip melakukan bisnis akad musyarakah masingmasing dari kedua pihak, baik itu pihak bank maupun pihak nasabah harus dapat mengelola usaha tersebut secara bersama-sama tanpa terkecuali. Jika terdapat pemilik modal yang tidak ikut melakukan dalam mengelola usahanya tetapi hanya menyerahkan modalnya saja maka hal ini disebut sebagai mitra yang pasif.

2. Apabila terjadi keuntungan dalam menjalankan usaha, maka akan dibagi secara rata sesuai dengan nisbah yang sudah disepakati pada awal akad. Dalam kontribusi modal yang sudah diberikan untuk menjalankan usaha, jika mendapatkan keuntungan maka besarnya nisbah tidak harus sama dengan modal yang diberikan pada usaha tersebut. Hal ini dikarenakan, dalam menjalankan bisnis pasti akan ada salah satu dari pemodal yang memiliki keahlian lebih dibandingkan dengan pemodal yang satunya, sehingga dalam pembagian keuntungan akan dibagi secara berbeda. Sedangkan jika terjadi kerugian dalam sebuah usaha tersebut maka, akan ditanggung secara bersama-sama sesuai dengan kontribusi besarnya setiap modal yang dikelurakan oleh masing-masing pihak yang sudah diserahkan diawal akad untuk menjalankan usaha tersebut. 
Misalnya terjadi kerugian maka harus ditanggung oleh dua pihak yaitu pihak mitra 1 sebagai lembaga keuangan syariah anugrah gusti sebesar $70 \%$ dan pihak ke 2 sebagai nasabah yang bernama tuan amirulah sebesar $30 \%$.

3. Apabila terjadi pengembalian modal dalam akad pembiayaan musyarakah, maka harus dilakukan dengan kesepakatan antara kedua pihak. Jika salah satu dari pemodal mengembalikan modalnya kepada pemodal lain dengan cara bertahap dan pada akhirnya modal tersebut kembali semua, maka usaha tersebut akan menjadi milik dari salah satu mitra dan akan disebut dengan akad pembiayaan musyarakah menurun. Sedangkan jika modal tersebut tidak dikembalikan sama sekali kepada pemodal lain maka akad tersebut disebut dengan akad pembiayaan musyarakah secara permanen.

\section{Cakupan Akuntansi Pembiayaan Musyarakah}

Dalam pelaksanaan transaksi akutansi pada akad pembiayaan musyarakah terdapat ketentuan yang berdasarkan pada PSAK (Pernyataan Standar Akuntansi Keuangan) No.106 tahun 2007 yang menjelaskan tentang Akuntansi Musyarakah. Dalam PSAK akan menjelaskan mengenai karakteristik dalam akad musyarakah, pengakuan dan pengukuran pada transaksi dalam akad musyarakah, penyajian dan pengukapan terhadap mitra pasif dan mitra aktif. Pada PSAK nomer 106 akan 
menjelaskan tentang mitra aktif yanng merupakan pihak yang menjelankan usaha dalam akad musyarakah yang dilakukan secara sendiri maupun pihak lain yang akan mengelolah usahannya. Sedangkan mitra pasif merupakan pihak yang tidak ikut dalam menjalankan usahanya pada akad musyarakah. Pada akad akuntansi pembiayaan musyarakah terdapat aplikasi dalam perbankan diantaranya sebagai berikut ${ }^{64}$ :

1. Adanya pembiayaan pada proyek

Pengaplikasian dalam akad pembiayaan musyarakah dilakukan dalam pembiayaan proyek, dalam hal ini antara pihak bank dan nasabah sama-sama harus menyediakan modal untuk dapat menjalankan usahanya dalam pembiayaan proyek tersebut. Apabila proyek sudah selesai maka, pihak nasabah harus mengembalikan modal itu beserta menyerahkan bagi hasil sesuai yang disepakai kepada pihak perbankan.

2. Modal ventura

Dalam akad musyarakah lembaga keuangan boleh menerapkan pelaksanaan investasi dalam kepemilikan suatu perusahaan karena skema dalam akad musyarakah menerapkan modal ventura. Model ventura dalam penanaman modalnya dilakukan dengan jangka waktu tertentu. Setelah melakukan hal tersebut, pihak bank akan menjual

${ }^{64}$ Khaddafi.hal 246-247. 
bagian dari sahamnya, baik itu secara langsung maupun secara bertahap.

\section{E. Akun Transaksi Pembiayaan Musyarakah}

\section{Mitra Aktif}

a. Pada saat mitra aktif menerima uang secara tunai kepada musyarakah

Db. Kas $x x x x x$

Kr. Investasi pada musyarakah xxxxx

b. Pada saat mitra aktif menerima uang non kas kepada musyarakah

1) Nilai wajar dalam aktiva yang diterima lebih rendah

Db. Aktiva pada non kas $\quad x x x x x$

$\mathrm{Kr}$. Kerugian penerimaan aktiva $\quad x x x x x$

$\mathrm{Kr}$. Investasi pada musyarakah $\mathrm{xxxxx}$

2) Nilai wajar dalam aktiva yang diterima lebih tinggi

Db. Aktiva pada non kas XXXXX

Kr. Keuntungan penerimaan aktiva $x x x x x$ $\mathrm{Kr}$. Investasi pada musyarakah $\quad$ xxxxx

c. Pengakuan dalam biaya akad musyarakah

1) Saat biaya dikeluarkan

Db. Beban pada akad musyarakah $X X X X X$ 
Kr. Kas

xxxxx

2) Terjadinya kesepakatan yang diakui sebgai bagian dari investasi musyarakah

Db. Beban pada akad musyarakah xxx

Kr. Investasi pada musyarakah

$\mathrm{XXX}$

d. Pembayaran pada keuntungan musyarakah

Db. Keuntungan bagi hasil musyarakah xxx

Kr. Kas

$\mathrm{xxx}$

e. Pengakuan terhadap kerugian dalam musyarakah tanpa ada kelalaian

Db. Investasi pada musyarakah $\quad$ xxx

Kr. Kerugian atas bagi hasil musyarakat $x x x$

f. Pengakuan terhadap kerugian yang disebabkan akibat kelalaian manajemen

Db. Investasi pada musyarakah $\quad$ xxx

Kr. Hutang kepada pihak mitra pasif $\quad x x x$

g. Pelunasan modal atas musyarakah dengan dialihkannya kepada pihak mitra lainnya Db. Investasi pada musyarakah

XXXXX

Kr. Kas

$x x x x x$ 
h. Pengembalian atas modal musyarakah berupa barang (non kas) dengan nilai wajar yang lebih rendah

Db. Investasi pada musyarakah XXXXX

Kr. Kerugian atas penyelesaian pembiayaan musyarakah

XXXXX

Kr. Aktiva pada non kas $\quad x x x x x$

i. Pengembalian atas modal musyarakah berupa non kas dengan nilai wajar yang ;ebih besar Db. Investasi pada musyarakah XXXXX

Db. Keuntungan dalam penyelesaian pembiayaan musyarakah $x x x x x$ Kr. Aktiva non kas $x x x x x$

j. Pada saat berakhirnya akad musyarakah sebelum jatuh tempo atau pada saat selesainya jatuh tempo dan investasi pada musyarakah belum dibayarkan kepada pihak mitra pasif Db. Investasi pada musyarakah $\mathrm{XXXXX}$ Kr. Hutang pada pihak mitra pasif $x x x x x$

\section{Mitra Pasif}

a. Pada saat mitra pasif membayarkan uang secara tunai kepada musyarakah 
Db. Pembiayaan pada musyarakah XXXXX

Kr. Kas

XXXXX

b. Pada saat mitra pasif menyerahkan uang non kas kepada musyarakah

1) Nilai wajar dalam aktiva yang diserahkan lebih rendah

Db. Pembiayaan pada musyarakah

$\mathrm{xxxxx}$

Db. Kerugian penyerahan aktiva

XXXXx

Kr. Aktiva non kas

$x x x x x$

2) Nilai wajar dalam aktiva yang diserahkan lebih tinggi

Db. Pembiayaan musyarakah xxxxx

Kr. Aktiva pada non kas

XXXXX

Kr. Keuntungan atas penyerahan aktiva

$x x x x x$

c. Pengakuan dalam biaya akad musyarakah

1) Saat biaya dikeluarkan

Db. Beban pada akad musyarakah

XXXXX

Kr. Kas

$x x x x x$ 
2) Terjadinya kesepakatan yang diakui sebagai bagian dari pembiayaan Db. Pembiayaan pada msuyarakah XXXXX

Kr. Beban pada akad musyarakah XXXXX

d. Penerimaan pada keuntungan musyarakah Db. Kas Xxxxx

Kr. Keuntungan atas bagi hasil musyarakah

XXXXX

e. Pengakuan terhadap musyarakah tanpa ada kelalaian dari pihak mitra

Db. Kerugian atas bagi hasil musyarakah XXXXX

Kr. Pembiayaan pada musyarakah XXXXX

f. Pengakuan terhadap kerugian yang disebabkan akibat kelalaian pihak mitra musyarakah Db. Piutang terhadap musyarakah XXXXX

Kr. Pembiayaan pada musyarakah xxxxx

g. Pelunasan modal terhadap musyarakah dengan mengalihkan kepada pihak mitra musyarakah lainnya

Db. Kas

$\mathrm{XXXXX}$ 
Kr. Pembiayaan pada musyarakah XXXXX

h. Pengembalian atas modal musyarakah dalam non kas dengan nilai wajar yang lebih rendah Db. Aktiva pada non kas $\quad$ xxxxx Db. Kerugian atas penyelesaian pembiayaan musyarakah $x x x x x$

Kr. Pembiayaan pada musyarakah XXXXX

i. Pengembalian atas modal musyarakah dalam bentuk barang (non kas) dengan nilai wajar yang; ;ebih tinggi Db. Aktiva pada non kas $x x x x x$ Kr. Keuntungan dalam penyelesaian pembiayaan musyarakah xxxxx Kr. Pembiayaan pada musyarakah xxxxx

j. Pada saat berakhirnya akad musyarakah sebelum jatuh tempo atau pada saat selesainya jatuh tempo dan pembiayaan pada musyarakah belum dibayarkan kepada pihak mitra Db. piutang kepada pihak mitra xxxxx Kr. Pembiayaan pada msuarakah $x x x x x$

3. Contoh mitra pasif Ilustrasi 1, Pemberian modal sebagai LKS (mitra pasif) kepada mitra aktif sebagai nasabah dalam bentuk modal secara tunai 
Pada kesepakatan antara bank syariah mandiri dengan perusahaan PT. sentosa melakukan kesepakatan kerjasama dengan memberikan masing-masing kontribusi dananya yaitu :

- Pihak bank syariah mendiri bertindak sebagai mitra pasif sebesar Rp. 1.000.000.000,-

- Pihak nasabah PT. Sentosa bertindak sebagai mitra aktif sebesar Rp. 500.000.000,-

- Untuk pembagian nisbah akan disepakati oleh kedua pihak dengan pembagian 40\%:60\%, dalam hal ini akan menggunakan prinsip profit/loss sharing atas pembagian hasil usahanya kelak.

- Kesepakatan perjanjian jangka waktu oleh kedua pihak yaitu selama 2 tahun dan akan terhitung dari mulai ditandatangani kesepakatan bersama pada tanggal 1 Januari 2010 hingga 31 Desember 2011.

- Pada tahap awal tanggal 5 Januari 2010 bank syariah mandiri akan mencairkan pembiayaan senilai Rp. 600.000.000,-

- Pada tahap kedua tanggal 15 januari 2010 bank syariah mandiri akan mencairkan kembali modalnya tersebut senilai Rp. 400.000.000,-

Adapun pembuatan jurnal dalam bank syariah mandiri yang bertindak sebagai pihak mitra pasif dalam transaksi diatas adalah sebagai berikut:

a. Pada tanggal 1 Januari 2010 terjadi persetujuan pada pembiayaan musyarakah, adapun jurnal 
yang harus dibuat dalam komitmen bank syariah mandiri sebesar jumlah pembiayaan yang sudah disepakati dan disetujui

\begin{tabular}{|c|c|c|c|}
\hline $\mathrm{Tgl}$ & Keterangan & Debet & Kredit \\
\hline \multirow[t]{2}{*}{$\begin{array}{l}1-1- \\
201 \\
0\end{array}$} & $\begin{array}{l}\text { Kontrak pada } \\
\text { komitmen } \\
\text { pembiayaan } \\
\text { musyarakah }\end{array}$ & $\begin{array}{l}\text { Rp. } \\
1.000 .000 .00 \\
0,-\end{array}$ & \\
\hline & $\begin{array}{l}\text { Kewajiban } \\
\text { komitmen } \\
\text { pada } \\
\text { pembiaya } \\
\text { an } \\
\text { musyaraka } \\
\text { h }\end{array}$ & & $\begin{array}{l}\text { Rp. } \\
1.000 .000 .00 \\
0,-\end{array}$ \\
\hline & $\begin{array}{ll}\text { b. } & \text { Pada } \\
& \text { penca } \\
& \text { pemb } \\
& \text { sebes }\end{array}$ & $\begin{array}{l}\text { nggal } 5 \text { Jan } \\
\text { n pada tah } \\
\text { aran pembia } \\
\text { Rp. } 600.000 .0\end{array}$ & $\begin{array}{l}\text { ri } 2010 \text { terjad } \\
\text { awal sebaga } \\
\text { an musyarakar }\end{array}$ \\
\hline
\end{tabular}

\begin{tabular}{|l|l|l|c|}
\hline \begin{tabular}{c} 
Tangga \\
\multicolumn{1}{|c|}{ I }
\end{tabular} & Keterangan & \multicolumn{1}{|c|}{ Debet } & Kredit \\
\hline $\begin{array}{l}\text { 5-1- } \\
2010\end{array}$ & $\begin{array}{l}\text { Pembiayaan } \\
\text { pada } \\
\text { musyarakah }\end{array}$ & $\begin{array}{l}\text { Rp. } \\
600.000 .000,\end{array}$ & \\
\hline
\end{tabular}




\begin{tabular}{|c|c|c|c|}
\hline & $\begin{array}{l}\text { Rek. } \\
\text { Mitra } \\
\text { aktif (PT. } \\
\text { Sentosa) }\end{array}$ & & $\begin{array}{l}\text { Rp. } \\
\text { 600.000.000, } \\
\text { - }\end{array}$ \\
\hline \multirow[t]{2}{*}{$\begin{array}{l}5-1- \\
2010\end{array}$} & $\begin{array}{l}\text { Kewajiban } \\
\text { terhadap } \\
\text { komitmen } \\
\text { pembiayaa } \\
\text { n } \\
\text { musyaraka } \\
\text { h }\end{array}$ & $\begin{array}{l}\text { Rp. } \\
\text { 600.000.000, } \\
\text { - }\end{array}$ & \\
\hline & $\begin{array}{l}\text { Kontrak } \\
\text { pada } \\
\text { komitmen } \\
\text { pembiayaan } \\
\text { musyarakah }\end{array}$ & & $\begin{array}{l}\text { Rp. } \\
\text { 600.000.000, } \\
\text { - }\end{array}$ \\
\hline
\end{tabular}

c. Pada tanggal 15 Januari 2010 terjadi pencairan kembali pada tahap kedua sebagai pembayaran pembiayaan musyarakah sebesar Rp. 400.000.000,-

\begin{tabular}{|c|c|c|c|}
\hline $\begin{array}{c}\text { Tangga } \\
\text { I }\end{array}$ & Keterangan & Debet & Kredit \\
\hline
\end{tabular}




\begin{tabular}{|c|c|c|c|}
\hline \multirow[t]{2}{*}{$\begin{array}{l}15-1- \\
2010\end{array}$} & $\begin{array}{l}\text { Pembiayaan } \\
\text { pada } \\
\text { musyarakah }\end{array}$ & $\begin{array}{l}\text { Rp. } \\
\text { 400.000.000, } \\
\text { - }\end{array}$ & \\
\hline & $\begin{array}{l}\text { Rek. } \\
\text { Mitra } \\
\text { aktif (PT. } \\
\text { Sentosa) }\end{array}$ & & $\begin{array}{l}\text { Rp. } \\
\text { 400.000.000, } \\
\text { - }\end{array}$ \\
\hline \multirow[t]{2}{*}{$\begin{array}{l}15-1- \\
2010\end{array}$} & $\begin{array}{l}\text { Kewajiban } \\
\text { terhadap } \\
\text { komitmen } \\
\text { pembiayaa } \\
\text { n } \\
\text { musyaraka } \\
\text { h }\end{array}$ & $\begin{array}{l}\text { Rp. } \\
\text { 400.000.000, } \\
\text { - }\end{array}$ & \\
\hline & $\begin{array}{l}\text { Kontrak } \\
\text { pada } \\
\text { komitmen } \\
\text { pembiayaan } \\
\text { musyarakah }\end{array}$ & & $\begin{array}{l}\text { Rp. } \\
\text { 400.000.000, } \\
\text { - }\end{array}$ \\
\hline
\end{tabular}

Ilustrasi 2, Pemberian modal sebagai LKS (mitra pasif) kepada mitra aktif sebagai nasabah dalam bentuk modal kas dan non kas

Bank syariah mandiri telah mensetujui kontrak kerjasama dengan pihak nasabah 
PT.Sentosa dengan menggunakan 2 modal yaitu modal kas secara tunai sebesar Rp. 500.000.000,dan modal non kas berupa 50 unit sebuah komputer server, 50 unit sebuah paket perangkat pheriperal yang bertujuan sebagai pendukung dalam suatu sistem informasi pada akuntansi yang akan diimplementasikan.

\begin{tabular}{|c|c|c|c|}
\hline $\begin{array}{l}\text { Nama } \\
\text { Barang }\end{array}$ & $\begin{array}{l}\text { Harga } \\
\text { Perolehan }\end{array}$ & Harga Pasar & $\begin{array}{l}\text { Keuntungan } \\
\text { Penyerahan } \\
\text { Aktiva }\end{array}$ \\
\hline $\begin{array}{l}50 \text { unit } \\
\text { sebuah } \\
\text { kompute } \\
\text { r server }\end{array}$ & $\begin{array}{l}\text { Rp. } \\
200.000 .000 \\
,-\end{array}$ & $\begin{array}{l}\text { Rp. } \\
250.000 .000\end{array}$ & $\begin{array}{l}\text { Rp. } \\
\text { 50.000.000,- }\end{array}$ \\
\hline $\begin{array}{l}50 \text { unit } \\
\text { sebuah } \\
\text { paket } \\
\text { perangka } \\
\mathrm{t} \\
\text { pheriper } \\
\text { al }\end{array}$ & $\begin{array}{l}\text { Rp. } \\
150.000 .000 \\
--\end{array}$ & $\begin{array}{l}\text { Rp. } \\
225.000 .000 \\
\text {,- }\end{array}$ & $\begin{array}{l}\text { Rp. } \\
75.000 .000,-\end{array}$ \\
\hline TOTAL & $\begin{array}{l}\text { Rp. } \\
350.000 .000\end{array}$ & $\begin{array}{l}\text { Rp. } \\
475.000 .000\end{array}$ & $\begin{array}{l}\text { Rp. } \\
125.000 .000 \\
\text {,- }\end{array}$ \\
\hline
\end{tabular}


Kontribusi modal yang diberikan oleh nasabah sebagai mitra aktif (PT.Sentosa) sebesar Rp. 500.000.000,-. Dan pada tanggal 3 Januari 2010 pihak bank syariah mandiri menyetujui kesepakatan kerjasama dengan pihak nasabah dalam pembiayaan musyarakah dengan jangka waktu 2 tahun. Dan dapat dihitung dari tanggal mulai terjadinya kesepakatan, untuk pembagian nisbah akan dibagi $40 \%$ untuk mitra pasif dan $60 \%$ untuk mitra aktif. Dalam hal ini, penyerahan modal secara tunai dan non kas akan diatur sesuai dengan akad antara lain :

- Tanggal 6 Januari 2010 nasabah PT. Sentosa akan menyerahkan modal kas secara tunai sebesar Rp. 500.000.000,-

- Tanggal 16 Januari 2010 nasabah PT. Sentosa akan menyerahkan modal non kas dengan berupa 50 unit komputer server

- Tanggal 26 Januari 2010 nasabah PT. Sentosa akan menyerahkan modal non kas dengan berupa 50 unit paket perangkat pheriperal

- Tanggal 27 Januari 2010 pembayaran atas beban pra akad untuk penelitian dalam kelayakan proyek sebesar Rp. 10.000.000,-

Adapun pembuatan jurnal dalam bank syariah mandiri yang bertinndak sebagai pihak mitra pasif dalam transaksi diatas adalah sebagai berikut:

a. Tanggal 3 Januari 2010 penandatanganan atas perjanjian akad musyarakah. 


\begin{tabular}{|l|l|l|l|}
\hline $\begin{array}{c}\text { Tangga } \\
\text { I }\end{array}$ & \multicolumn{1}{|c|}{ Keterangan } & \multicolumn{1}{|c|}{ Debet } & \multicolumn{1}{|c|}{ Kredit } \\
\hline 3-1- & Kontrak pada & Rp. & \\
& $\begin{array}{l}\text { komitmen } \\
\text { pembiayaan } \\
\text { musyarakah }\end{array}$ & 500.000 .000 & \\
\cline { 2 - 4 } & Kewajiban & & \\
& komitmen & & Rp. \\
& pada & & 500.000 .000 \\
& pembiayaa & &,- \\
& $\mathrm{n}$ & & \\
& musyaraka & & \\
& h & & \\
\hline
\end{tabular}

b. Tanggal 4 Junuari 2010 pembelian komputer server dan perangkat pheriperalnya ditoko komputer jaya lestari yang dilakukan oleh Bank mandiri syariah

\begin{tabular}{|l|l|l|l|}
\hline Tanggal & Keterangan & \multicolumn{1}{|c|}{ Debet } & \multicolumn{1}{|c|}{ Kredit } \\
\hline $\begin{array}{l}\text { 4-1- } \\
2010\end{array}$ & Persediaan & $\begin{array}{l}\text { Rp. } \\
350.000 .000,-\end{array}$ \\
\cline { 2 - 4 } & & & $\begin{array}{l}\text { Rp. } \\
\end{array}$ \\
\cline { 3 - 4 } & & & $350.000 .000,-$ \\
\hline
\end{tabular}


c. Tanggal 6 Januari 2010 penyerahan atas modal kas secara tunai oleh pihak nasabah PT. Sentosa sebesar Rp. 500.000.000,-

\begin{tabular}{|c|c|c|c|}
\hline Tgl & Keterangan & Debet & Kredit \\
\hline \multirow[t]{2}{*}{$\begin{array}{l}6-1- \\
2010\end{array}$} & $\begin{array}{l}\text { Pembiayaan pada } \\
\text { musyarakah }\end{array}$ & $\begin{array}{l}\text { Rp. } \\
\text { 500.000.000 }\end{array}$ & \\
\hline & $\begin{array}{l}\text { Rekening mitra } \\
\text { aktif }\end{array}$ & & $\begin{array}{l}\text { Rp. } \\
500.000 .000\end{array}$ \\
\hline \multirow[t]{2}{*}{$\begin{array}{l}6-1- \\
2010\end{array}$} & $\begin{array}{l}\text { Kewajiban terhadap } \\
\text { komitmen } \\
\text { pembiayaan } \\
\text { musyarakah }\end{array}$ & $\begin{array}{l}\text { Rp. } \\
500.000 .000\end{array}$ & \\
\hline & $\begin{array}{l}\text { Kontrak terhadap } \\
\text { komitmen } \\
\text { pembiayaan } \\
\text { musyarakah }\end{array}$ & & $\begin{array}{l}\text { Rp. } \\
\text { 500.000.000,- }\end{array}$ \\
\hline
\end{tabular}

d. Tanggal 15 Januari 2010 penyerahan kepada pihak nasabah PT.Sentosa atas modal non kas dengan berupa 50 unit komputer server 


\begin{tabular}{|l|l|l|l|}
\hline \multirow{3}{*}{$\begin{array}{l}\text { 15-1- } \\
\text { 2010 }\end{array}$} & $\begin{array}{l}\text { Pembiayaan } \\
\text { pada musyarakah }\end{array}$ & Rp. 250.000.000,- & \\
\cline { 2 - 4 } & $\begin{array}{l}\text { Keuntungan } \\
\text { atas } \\
\text { penyerahan } \\
\text { aktiva }\end{array}$ & & Rp. \\
& Persediaan & & \\
\cline { 2 - 4 } & pada aktiva & & Rp. \\
\hline & & $2000.000,-$ \\
\hline
\end{tabular}

e. Tanggal 26 Januari 2010 penyerahan kepada pihak nasabah PT. Sentosa atas modal non kas dengan berupa perangkat paket pheriperal 50 unit

\begin{tabular}{|c|l|l|l|}
\hline $\begin{array}{c}\text { Tangga } \\
\text { I }\end{array}$ & \multicolumn{1}{|c|}{ Keterangan } & \multicolumn{1}{|c|}{ Debet } & \multicolumn{1}{|c|}{ Kredit } \\
\hline $\begin{array}{c}\text { 26-1- } \\
2010\end{array}$ & $\begin{array}{l}\text { Pembiayaan } \\
\text { pada } \\
\text { musyarakah }\end{array}$ & $\begin{array}{l}\text { Rp. } \\
\text { 225.000.000, }\end{array}$ & \\
\cline { 2 - 4 } & Keuntunga & & \\
& n atas & & Rp. \\
& penyeraha & & 75.000 .000$, \\
& n aktiva & & - \\
& Persediaan & & \\
\cline { 2 - 4 } & pada & & Rp. \\
& aktiva & & 150.000 .00$, \\
& & & - \\
\hline
\end{tabular}


f. Jika komputer server sebagai modal kas yang mengalami penurunan harga menjadi $\mathrm{Rp}$. 150.000.000,-

\begin{tabular}{|l|l|l|l|}
\hline Tanggal & Keterangan & \multicolumn{1}{|c|}{ Debet } & \multicolumn{1}{|c|}{ Kredit } \\
\hline $\begin{array}{l}\text { 26-1- } \\
2010\end{array}$ & $\begin{array}{l}\text { Pembiayaan } \\
\text { pada musyarakah }\end{array}$ & Rp. 150.000.000,- & \\
\cline { 2 - 4 } & $\begin{array}{l}\text { Kerugian atas } \\
\text { penyerahan } \\
\text { aktiva }\end{array}$ & & $\begin{array}{l}\text { Rp. } \\
\end{array}$ \\
\cline { 2 - 4 } & Persediaan & & $50.000 .000,-$ \\
& pada aktiva & & Rp. \\
& & & $200.000 .00,-$ \\
\hline
\end{tabular}

g. Tanggal 27 Januari 2010 pengeluaran atas biaya pra akad sebagai perencanaan kerjasama musyarakah

\begin{tabular}{|l|l|l|l|}
\hline Tanggal & Keterangan & \multicolumn{1}{|c|}{ Debet } & \multicolumn{1}{|c|}{ Kredit } \\
\hline $\begin{array}{l}27-1- \\
2010\end{array}$ & $\begin{array}{l}\text { Uang muka } \\
\text { akad } \\
\text { musyarakah }\end{array}$ & $\begin{array}{l}\text { Rp. } \\
10.000 .000,-\end{array}$ & \\
\cline { 2 - 4 } & Kas & & $\begin{array}{l}\text { Rp. } \\
\end{array}$ \\
& & & $10.000 .000,-$ \\
\hline
\end{tabular}


h. Tanggal 27 Januari 2010 pembayaran atas pengakuan biaya dalam akad musyarakah Beban yang diakui

\begin{tabular}{|c|l|l|l|}
\hline $\begin{array}{c}\text { Tangga } \\
\text { I }\end{array}$ & \multicolumn{1}{|c|}{ Keterangan } & \multicolumn{1}{|c|}{ Debet } & \multicolumn{1}{|c|}{ Kredit } \\
\hline $\begin{array}{l}27-1- \\
2010\end{array}$ & Biaya akad & $\begin{array}{l}\text { Rp. } \\
10.000 .000,\end{array}$ & \\
& & - & \\
\cline { 2 - 4 } & Uang muka & & Rp. \\
& $\begin{array}{c}\text { pada akad } \\
\text { musyaraka } \\
\end{array}$ & & 10.000 .000$, \\
& h & - \\
\hline
\end{tabular}

Kesepakatan berdasarkan dengan pengakuan pada pembiayaan antara kedua pihak

\begin{tabular}{|c|l|l|l|}
\hline $\begin{array}{c}\text { Tangga } \\
\text { I }\end{array}$ & \multicolumn{1}{|c|}{ Keterangan } & \multicolumn{1}{|c|}{ Debet } & Kredit \\
\hline $\begin{array}{l}27-1- \\
2010\end{array}$ & $\begin{array}{l}\text { Pembiayaan } \\
\text { pada }\end{array}$ & Rp. & \\
& musyakarah & - & \\
\hline
\end{tabular}




\begin{tabular}{|l|l|l|l|}
\hline & Uang muka & & Rp. \\
pada akad & & 10.000 .000$, \\
musyaraka & & - \\
h & & \\
\hline
\end{tabular}

i. Jika terdapat biaya administasi atas pengurusan akad oleh bank syariah mandiri dan biaya jasa notaris sebesar Rp. 5.000.000,-

\begin{tabular}{|l|l|l|l|}
\hline Tanggal & \multicolumn{1}{|c|}{ Keterangan } & \multicolumn{1}{|c|}{ Debet } & \multicolumn{1}{|c|}{ Kredit } \\
\hline $27-1-$ & $\begin{array}{l}\text { Rekening kas } \\
\text { mitra aktif } \\
\text { (PT.Sentosa) }\end{array}$ & $\begin{array}{l}\text { Rp. } \\
\text { (P.000.000,- }\end{array}$ & \\
\cline { 2 - 4 } & $\begin{array}{l}\text { Pendapatan } \\
\text { notaris (non } \\
\end{array}$ & & Rp. \\
& operasional) & & $5.000 .000,-$ \\
\hline
\end{tabular}

j. Pembayaran yang dilakukan oleh bank syariah mandiri untuk biaya jasa notaris sebesar Rp. 5.000.000,-

\begin{tabular}{|l|l|l|l|}
\hline Tanggal & \multicolumn{1}{|c|}{ Keterangan } & \multicolumn{1}{|c|}{ Debet } & Kredit \\
\hline $\begin{array}{l}27-1- \\
2010\end{array}$ & $\begin{array}{l}\text { Biaya admin } \\
\text { akad }\end{array}$ & $\begin{array}{l}\text { Rp. } \\
5.000 .000,-\end{array}$ & \\
\hline
\end{tabular}




\begin{tabular}{|l|l|l|l|}
\hline & Kas & & Rp. \\
& & & $5.000 .000,-$ \\
\hline
\end{tabular}

4. Contoh penerimaan modal dari mitra aktif sebagai nasabah dalam bentuk modal secara tunai

Bank syariah mandiri melakukan kesepakatan dengan pihak nasabah (PT.Sentosa) dan akan memberikan kontribusi dana setiap masing-masing pihak yaitu

1) Bank syariah mandiri (Mitra aktif) memberikan dana sebesar Rp. 500.000.000,-

2) Nasabah PT.Sentosa (Mitra Pasif) memberikan dana sebesar Rp. 1.000.000.000,-

3) Dalam pembagian nisbah akan dibagi $40 \%$ (mitra pasif) dan 60\% (mitra aktif) dengan menggunakan profit loss sharing untuk sistem pembagian usahanya.

4) Kesepakatan dalam jangka waktu selama 2 tahun dan akan terhitung dari pelaksanaan penandatanganan atas perjanjian akad musyarakah sejak tanggal 1 Januari 2010 hingga 31 Desember 2011

5) Pada tahap awal tanggal 5 Januari 2010 bank syariah mandiri akan mencairkan pembiayaan senilai Rp. 600.000.000,- 
6) Pada tahap kedua tanggal 15 januari 2010 bank syariah mandiri akan mencairkan kembali modalnya tersebut senilai Rp. 400.000.000,

Adapun pembuatan jurnal pada bank syariah mandiri yang bertindak sebagai pihak mitra aktif dalam transaksi diatas adalah sebagai berikut:

a. Pada tanggal 1 Januari 2010 terjadi penerimaan atas investasi musyarakah yang telah disetujui

\begin{tabular}{|l|l|l|l|}
\hline Tanggal & Keterangan & Debet & Kredit \\
\hline $\begin{array}{l}1-1- \\
2010\end{array}$ & $\begin{array}{l}\text { Hak komitmen } \\
\text { atas pembiayaan } \\
\text { musyarakah }\end{array}$ & $\begin{array}{l}\text { Rp. } \\
1.000 .000 .000,-\end{array}$ & \\
\cline { 2 - 4 } & $\begin{array}{l}\text { Kontrak } \\
\text { komitmen atas } \\
\text { pembiayaan } \\
\text { musyarakah }\end{array}$ & & Rp. \\
\hline
\end{tabular}

b. Pada tanggal 5 Januari 2010 terjadi pembayaran pada tahap awal atas pembayaran pembiayaan musyarakah sebesar Rp. 600.000.000,-

\begin{tabular}{|l|l|l|l|}
\hline Tanggal & Keterangan & Debet & Kredit \\
\hline
\end{tabular}




\begin{tabular}{|l|l|l|l|}
\hline $\begin{array}{l}\text { 5-1- } \\
2010\end{array}$ & $\begin{array}{l}\text { Rekening mitra } \\
\text { pasif } \\
\text { (PT.Sentosa) }\end{array}$ & $\begin{array}{l}\text { Rp. } \\
600.000 .000,-\end{array}$ \\
\cline { 2 - 4 } & $\begin{array}{l}\text { Investasi pada } \\
\text { musyarakah }\end{array}$ & & $\begin{array}{l}\text { Rp. } \\
600.000 .000,-\end{array}$ \\
\hline
\end{tabular}

Investasi pada musyarakah atas kategori sebagai dana syirkah temporer.

\begin{tabular}{|l|l|l|l|}
\hline Tanggal & Keterangan & Debet & Kredit \\
\hline $\begin{array}{l}5-1- \\
2010\end{array}$ & $\begin{array}{l}\text { Kontrak } \\
\text { terhadap } \\
\text { komitmen } \\
\text { pembiayaan } \\
\text { musyarakah }\end{array}$ & $\begin{array}{l}\text { Rp. } \\
\text { 600.000.000,- }\end{array}$ & \\
\cline { 2 - 4 } & $\begin{array}{l}\text { Hak komitmen } \\
\text { atas } \\
\text { pembiayaan } \\
\text { musyarakah }\end{array}$ & & \\
\hline
\end{tabular}

c. Pada tanggal 15 Januari 2010 terjadi pencairan kembali pada tahap kedua sebagai pembayaran pembiayaan musyarakah sebesar Rp. 400.000.000,- 


\begin{tabular}{|l|l|l|l|}
\hline Tanggal & Keterangan & Debet & Kredit \\
\hline $15-1-$ & Rekening mitra & Rp. & \\
2010 & pasif(PT.Sentosa) & $400.000 .000,-$ & \\
\cline { 2 - 4 } & $\begin{array}{l}\text { Investasi pada } \\
\text { musyarakah }\end{array}$ & & Rp. \\
& & $400.000 .000,-$ \\
\hline
\end{tabular}

Investasi pada musyarakah atas kategori sebagai dana syirkah temporer.

\begin{tabular}{|l|l|l|l|}
\hline Tanggal & Keterangan & Debet & Kredit \\
\hline $\begin{array}{l}5-1- \\
2010\end{array}$ & $\begin{array}{l}\text { Kontrak } \\
\text { terhadap } \\
\text { komitmen } \\
\text { pembiayaan } \\
\text { musyarakah }\end{array}$ & $\begin{array}{l}\text { Rp. } \\
\text { 400.000.000,- }\end{array}$ & \\
\cline { 2 - 4 } & $\begin{array}{l}\text { Hak komitmen } \\
\text { atas } \\
\text { pembiayaan } \\
\text { musyarakah }\end{array}$ & & \\
\hline
\end{tabular}




\section{F. Rangkuman}

Akad musyarakah merupakan salah satu akad kerja sama yang dilakukan oleh dua belah pihak atau lebih yang setiap pihak memberikan kontribusi dana, apabila mendapatkan keuntungan maka akan dibagi secara rata, apbila terjadi kerugian maka ditanggung sesuai porsi kontribusi dana.

Akuntansi musyarakah terdiri dari 2 pihak yaitu pihak mitra aktif dan pihak mitra pasif. Kedua pihak ini memiliki hak dan kewajiban yang berbeda atas usaha yang dijalankan serta klasifikasi berbeda pada laporan akuntansinya.

Akuntansi musyarakah memiliki karakteristik, sebagai berikut :

1. Kedua pihak mitra menyediakan dana untuk suatu usaha yang akan dijalankan.

2. Investasi musyarakah diberikan dalam bentuk kas dan setara kas

3. Dana mitra pihak satu tidak dapat dijaminkan pada pihak mitra lainnya.

4. Jika tidak ada kejelasan penyelesaian antara kedua pihak bermasalah, kesalahan itu harus dibuktikan berdasarkan keputusan institusi yang berwenang.

5. Porsi bagi hasil bagi para mitra ditentukan berdasarkan nisbah yang telah disepakati dari 
pendapatan usaha selama periode akad bukan dari jumlah investasi yang disalurkan.

\section{G. Studi Kasus Transaksi Pembiayaan Musyarakah}

\section{Soal mitra pasif 1}

Pemberian modal antara pihak mitra pasif dan mitra aktif dalam bentuk modal secara tunai.

BRI syariah dengan perusahaan PT. jaya lestari melakukan kesepakatan kerjasama dengan memberikan masing-masing kontribusi dananya yaitu :

1. BRI syariah bertindak sebagai mitra pasif yang memberikan modal sebesar Rp. 900.000.000,-

2. Pihak nasabah PT. jaya lestari bertindak sebagai mitra aktif sebesar Rp. 400.000.000,-

3. Untuk pembagian nisbah disepakati dengan pembagian 40\%:60\%, dalam hal ini akan menggunakan prinsip profit/loss sharing atas pembagian hasil usahanya kelak.

4. Kesepakatan perjanjian jangka waktu oleh kedua pihak yaitu selama 2 tahun dan akan terhitung dari mulai ditandatangani kesepakatan bersama pada tanggal 1 Januari 2019 hingga 31 Desember 2020.

5. Pada tahap awal tanggal 5 Januari 2010 bank syariah mandiri akan mencairkan pembiayaan senilai Rp. 550.000.000,-

6. Pada tahap kedua tanggal 15 januari 2010 bank syariah mandiri akan mencairkan kembali modalnya tersebut senilai Rp. 350.000.000,- 
Buatlah jurnal pada BRI syariah yang bertindak sebagai mitra pasif!

\section{Soal mitra pasif 2}

Pemberian modal antara pihak mitra pasif dan mitra aktif dalam bentuk modal kas dan non kas.

BRI syariah telah mensetujui kontrak kerjasama dengan pihak nasabah PT. Jaya Lestari dengan menggunakan 2 modal yaitu modal kas secara tunai sebesar Rp. 700.000.000,- dan modal non kas berupa 70 unit meja kerja karyawan, 200 unit komputer .

\begin{tabular}{|l|l|l|l|}
\hline $\begin{array}{l}\text { Nama } \\
\text { Barang }\end{array}$ & $\begin{array}{l}\text { Harga } \\
\text { Perolehan }\end{array}$ & Harga Pasar & $\begin{array}{l}\text { Keuntungan } \\
\text { Penyerahan } \\
\text { Aktiva }\end{array}$ \\
\hline $\begin{array}{l}70 \quad \text { unit } \\
\text { meja kerja } \\
\text { karyawan }\end{array}$ & $\begin{array}{l}\text { Rp. } \\
170.000 .000,-\end{array}$ & $\begin{array}{l}\text { Rp. } \\
210.000 .000,-\end{array}$ & $\begin{array}{l}\text { Rp. } \\
40.000 .000,-\end{array}$ \\
\hline $\begin{array}{l}200 \text { unit } \\
\text { komputer }\end{array}$ & $\begin{array}{l}\text { Rp. } \\
250.000 .000,-\end{array}$ & $\begin{array}{l}\text { Rp. } \\
300.000 .000,-\end{array}$ & $\begin{array}{l}\text { Rp. } \\
50.000 .000,-\end{array}$ \\
\hline TOTAL & $\begin{array}{l}\text { Rp. } \\
420.000 .000,-\end{array}$ & $\begin{array}{l}\text { Rp. } \\
510.000 .000,-\end{array}$ & $\begin{array}{l}\text { Rp. } \\
90.000 .000,-\end{array}$ \\
\hline
\end{tabular}

Kontribusi pada modal yang diberikan oleh nasabah sebagai mitra aktif (PT.Jaya lestari) sebesar Rp. 
700.000.000,-. Dan pada tanggal 4 Januari BRI Syariah menyetujui kesepakatan kerjasama dengan pihak nasabah dalam pembiayaan musyarakah dengan jangka waktu 2 tahun. Dan dapat dihitung dari tanggal mulai terjadinya kesepakatan, untuk pembagian nisbah akan dibagi $40 \%$ untuk mitra pasif dan $60 \%$ untuk mitra aktif. Dalam hal ini, penyerahan modal secara tunai dan non kas akan diatur sesuai dengan akad antara lain :

a. Tanggal 8 Januari 2010 nasabah PT. jaya lestari akan menyerahkan modal kas secara tunai sebesar Rp. 700.000.000,-

b. Tanggal 18 Januari 2010 nasabah PT. jaya lestari akan menyerahkan modal non kas dengan berupa 70 unit meja kerja karyawan

c. Tanggal 25 Januari 2010 nasabah PT. lestari akan menyerahkan modal non kas dengan berupa 200 unit komputer

d. Tanggal 28 Januari 2010 pembayaran atas beban pra akad untuk penelitian dalam kelayakan proyek sebesar Rp. 20.000.000,-

Buatlah transaksi jurnal pada BRI syariah yang bertindak sebagai mitra pasif !

Soal mitra aktif 3, penerimaan modal dari mitra aktif sebagai nasabah dalam bentuk modal secara tunai

1. Bank syariah mandiri (Mitra aktif) memberikan dana sebesar Rp. 400.000.000,- 
2. Nasabah PT.Jaya Lestari (Mitra Pasif) memberikan dana sebesar Rp. 9.000.000.000,-

3. Dalam pembagian nisbah akan dibagi $40 \%$ (mitra pasif) dan $60 \%$ (mitra aktif) menggunakan profit loss sharing untuk sistem pembagian usahanya.

4. Kesepakatan dalam jangka waktu selama 2 tahun dan akan terhitung dari pelaksanaan penandatanganan atas perjanjian akad musyarakah sejak tanggal 1 Januari 2019 hingga 31 Desember 2020

5. Pada tahap awal tanggal 5 Januari 2010 bank syariah mandiri akan mencairkan pembiayaan senilai Rp. 550.000.000,-

6. Pada tahap kedua tanggal 15 januari 2010 bank syariah mandiri akan mencairkan kembali modalnya tersebut senilai Rp. 350.000.000,

Buatlah transaksi jurnal pada BRI syariah yang bertindak sebagai pihak mitra ! 


\section{BAB VIII}

\section{TEORI DAN PRAKTEK AKUNTANSI TRANSAKSI IJARAH}

\section{Kompetensi Dasar}

Setelah mempelajari bab ini, diharapkan membentuk mahasiswa yang kompeten dalam hal berikut :

1. Mampu melakukan pencatatan transaksi akuntansi dengan akad ljarah dan ijarah muntahiya Bittamlik.

2. Pemahaman terhadap pengakuan dan pengukuran, penyajian serta pengungkapan akuntansi ljarah dan ijarah muntahiya Bittamlik.

\section{Indikator}

Indikator yang ada dalam bab ini, sebagai berikut :

1. Kemampuan proses akuntansi untuk transaksi akad ljarah dan ijarah muntahiya Bittamlik.

\section{Materi Pokok}

Materi utama pada bab ini adalah Akuntansi penyaluran dana dengan akad ljarah dan ijarah muntahiya Bittamlik.

\section{A. Definisi ljarah}

"Ijarah" berasal dari bahasa Arab yang disebut "lijaar" yang memiliki arti "memberi upah" atau "menyewa", dan ada makna yang lain yaitu "menyewakan" atau "menjual jasa". Tetapi dalam 
ilmu Fiqih istilah ljarah adalah memberi upah, sewa menyewa dan menjual jasa atau perdagangan jasa ${ }^{65}$.

Al-ljarah salah satu nama untuk upah, yaitu sesuatu yang diberikan berupa upah terhadap sebuah pekerjaan ${ }^{66}$. Sedangkan menurut DSN-MUI, ljarah adalah akad pemidahan hak guna manfaat suatu barang atau jasa dala waktu tertentu melalui pembayaran sewa tanpa diikuti dengan pemindahan barang itu sendiri ${ }^{67}$.

ljarah sebagai suatu transaksi yang memiliki sifat tolong menolong dan memiliki landasan yang kuat dalam Al-Qur'an dan Al-Hadits ${ }^{68}$. Dalam Al-Baqarah ayat 233 yang mempunyai arti "Dan jika kamu ingin anakmu disusukan oleh orang lain, maka tidak ada dosa bagimu apabila kamu memberikan pembayaran menurut yang patut. Bertakwalah kamu kepada Allah dan ketahuilah bahwa Allah Maha Melihat apa yang

${ }^{65}$ S.Ag M. Baidlowi Mufti, BA, Drs. Mahmud Yunus, Drs. H. Masroni, M.Pdl, M. Yusub, S. Ag. MP.dl, Mustofa, FIQIH, 2016.

${ }^{66}$ Nasrulloh Ali Munif, "BITTAMLIK DALAM PERSPEKTIF HUKUM ISLAM DAN HUKUM POSITIF DI INDONESIA," Jurnal An-Nisbah 03, no. Article 1319 (2017).

${ }^{67}$ Miko Polindi, "IMPLEMENTASI IJARAH DAN IJARAH MUNTAHIA BIT-TAMLIK (IMBT) DALAM PERBANKAN SYARIAH DI INDONESIA," Jurnal Al-Intaj 2, no. 1 (2016).

${ }^{68}$ Melani Puspitasari Daffa Muhammad Dzubyan, Erina Azzahra, "ANALISIS AKAD IJARAH MUNTAHIYA BITTAMLIK (IMBT) DALAM PERSPEKTIF HUKUM ISLAM DAN HUKUM POSITIF DI INDONESIA," Jurnal Ekonomi dan Keuangan Syariah 3, no. 2 (2019): 181-196. 
kamu kerjakan" dan dalam Hadits yang diriwayatkan Ibnu Majah yang artinya "Berikanlah kepada pekerja upahnya sebelum mengering keringatnya" ${ }^{69}$

Kita mengetahui bahwa akad ljarah adalah akad yang sebelumnya sudah dicontohkan oleh nabi Muhammad SAW. Asas kebolehan dan kebebasan inovasi dalam akad syariah telah dijamin oleh UndangUndang Nomor 21 tahun 2008 yaitu tentang perbankan syariah, lebih tepatnya pada pasal 19 yang sering disebutkan "...atau akad lain yang tidak bertentangan dengan prinsip syariah".70

\section{B. Rukun Pembiayaan ljarah}

Menurut Mazhab Hanafi, rukun ijarah hanya ada satu yaitu ijab dan qabul. ljab merupakan suatu ungkapan menyewakan sedangkan qabul yaitu persetujuan untuk sewa menyewa ${ }^{71}$.

Menurut pendapat jumhur ulama, rukun al-ljarah ada 4 yaitu:

a. Orang yang beraqad, yakni pihak yang mempunyai barang menyewakan barangnya

\footnotetext{
${ }^{69}$ M.Kn Sriono, SH, "TELAAH TERHADAP PERJANJIAN SEWA MENYEWA," Jurnal Ilmiah "Advokasi" 01, no. 01 (2013): 88-98.

${ }^{70}$ Nasrulloh Ali Munif, "ISLAM DAN HUKUM POSITIF DI INDONESIA," Jurnal AHKAM 4, no. article 1319 (2016): 57-80.

${ }^{71}$ Husain Insawan, Fakultas Ekonomi, and Islam Iain, "A I - I Jarah Dalam Perspektif Hadis;KajianHadisdengan Metode M Audhu'iy," Jurnal Studi Ekonomi dan Bisnis Islam 2, no. 1 (2017).
} 
kepada orang yang membutuhkan manfaat barang tersebut.

b. Sewa atau Imbalan

c. Manfaat

d. Shighat (ljab Qabul) ${ }^{72}$

Syarat ijarah yang harus ada agar terpenuhi ketentuan-ketentuan hukum Islam, sebagai berikut:

a. Jasa atau manfaat yang akan diberikan oleh aset yang disewakan tersebut harus tertentu dan diketahui dengan jelas oleh kedua belah pihak.

b. Kepemilikan aset tetap pada yang menyewakan yang bertanggung jawab pemeliharaannya, sehingga aset tersebut harus dapat memberi manfaat kepada penyewa.

c. Akad ijarah dihentikan pada saat aset yang bersangkutan berhenti.

d. memberikan manfaat kepada penyewa. Jika aset tersebut rusak dalam periode kontrak, akad ijarah masih tetap berlaku.

${ }^{72}$ H. Sulaiman Rasjid, FIQH ISLAM, 1998. 


\section{Skema Pembiayaan ljarah}

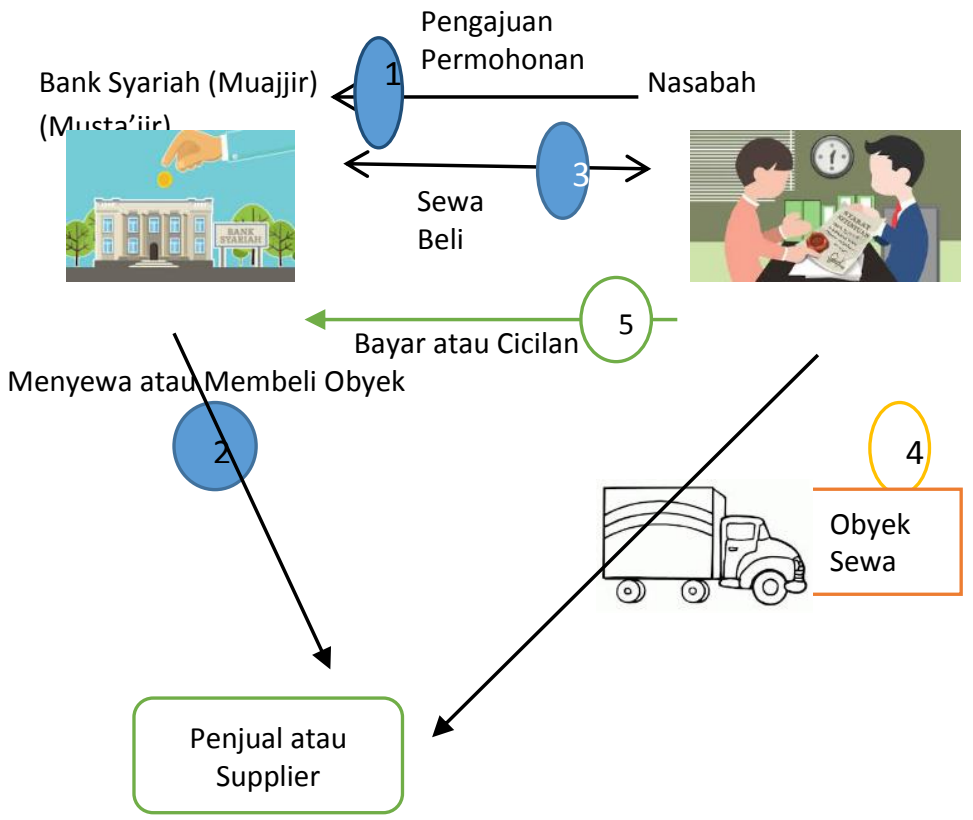

Keterangan :

1. Nasabah mengajukan pembiayaan ijarah ke bank syariah.

2. Bank syariah membeli/menyewa barang yang diinginkan oleh nasabah sebagai objek ijarah, dari supplier/penjual/pemilik. 
3. Setelah dicapai kesepakatan antara nasabah dan bank mengenai barang objek ijarah, tarif ijarah, periode ijarah dan biaya pemeliharaannya, maka akad pembiayaan ijarah ditanda tangani. Nasabah diwajibkan menyerahkan jaminan yang dimiliki.

4. Bank menyerahkan objek ijarah kepada nasabah sesuai akad yang disepakati. Setelah periode ijarah berakhir, nasabah mengembalikan objek ijarah tersebut kepada bank.

5. Bila bank memebeli objek ijarah tersebut (albai' wal ijarah) maka setelah periode ijarah berakhir objek ijarah tersebut disimpan oleh bank sebagai asset yang dapat disewakan kembali.

6. Bila bank menyewa objek ijarah tersebut (al ijarah wal ijarah, atau ijarah pararel), maka setelah periode tersebut dikembalikan oleh bank kepada supplier/ penjual/ pemilik.

\section{Cakupan Akuntansi Pembiayaan ljarah}

Pada PSAK 107 membahas mengenai Akuntansi ljarah menjelaskan terkait tujuannya ialah untuk mengatur pengakuan, pengukuran, penyajian, dan pengungkapan pada transaksi ijarah. Aturan yang mencakup yaitu :

1. Pernyataan ini diperuntukkan bagi semua entitas yang bertransaksi ijarah. 
2. Pernyataan ini mencakup aturan atas pembiayaan multijasa dengan akad ijarah, tetapi bukan mencakup peraturan perlakuan akuntansi untuk obligasi syariah (sukuk) yang menggunakan akad ijarah.

Dalam PSAK 107 tertuang mengenai Akuntansi Multijasa yang menggunakan prinsip ljarah. Untuk memberikan gambaran perbedaan segi akuntansi IMBT dengan Sewa Beli, beberapa ketentunan PSAK 30 terkait Sewa (revisi 2007), seperti:

\section{Sewa pembiayaan (dalam laporan keuangan lessee)}

1. Diawal sewa, sewa pembiayaan diakui oleh lesse sebagai aset dan kewajiban dalam neraca sebesar nilai wajar aset sewa. Tingkat diskonto yang dipakai dalam perhitungan nilai dari pembayaran sewa minimum adalah tingkat suku bunga implisit pada sewa. Biaya awal yang dikeluarkan oleh lessee akan diakui sebagai aset.

2. Transaksi lain dicatat dan disajikan sesuai dengan subtansi dan realita keuangan. Meskipun secara legal lessee tidak memperoleh aset sewa pada pembiayaan. Tetapi secara subtansi dan realita, pihak lessee mendapatkan manfaat ekonomis dari pemakaian aset sewa itu selama umur ekonomisnya berlaku. Dan konsekuensinya lessee harus menanggung kewajiban atas pembayaran hak tersebut sebesar jumlah awal sewa. 
3. Sumber ekonomi dan tingkat kewajiban entitas menjadi rendah apabila transaksi sewa tidak tercantum dalam neraca lessee sehingga mendistorsi rasio-rasio keuangan. Maka, sewa pembiayaan diakui sebagai asset dan kewajiban atas pembayaran sewa dimasa depan pada neraca lessee.

4. Kewajiban sewa tidak boleh diakui sebagai pengurang aset sewa dalam laporan keuangan. Penyajian kewajiban pada neraca berbeda antara kewajiban jangka pendek dan kewajiban jangka panjang, tetapi berlaku sama untuk kewajiban sewa.

5. Biaya awal yaitu sejalan dengan aktivitas sewa, seperti aktivitas pemastian dan negosiasi atas sewa. Biaya yang didistribusikan langsung kepada lessee untuk sewa pembiayaan ditambahkan ke jumlah yg diakui sebagai aset.

\section{Sewa pembiayaan (dalam laporan keuangan lessor)}

1. Pada pembiayaan sewa, pengakuan lessor atas aset berupa piutang sewa pembiayaan pada neraca sebesar jumlah investasi sewa neto tersebut.

2. Pada sewa pembiayaan segala risiko dan manfaat yang terkait dengan kepemilikan legal dialihkan lessor kepada lessee. Piutang sewa yang diterima oleh lessor merupakan pembayaran pokok dan penghasilan pembiayaan yang diterima lessor 
sebagai ganti dan imbalan atas investasi dan jasanya.

3. Lessor mengeluarkan biaya langsung awal meliputi biaya legal, komisi dan biaya internal yang didistribusikan langsung pada negosiasi di aturan sewa. Biaya langsung awal tidak termasuk biaya umum seperti yang dikeluarkan oleh tim pemasaran. Untuk sewa pembiayaan, selain yang melibatkan lessor dealer atau lainnya, biaya langsung awal diperhitungkan sebagai pengukuran awal piutang sewa pembiayaan dan mengurangi penghasilan yang diakui selama masa sewa. Tingkat bunga implisit dalam sewa ditentukan sedemikian rupa sehingga biaya langsung awal secara otomatis, sehingga tidak perlu adanya pengungkapan terpisah. Biaya yang dikeluarkan oleh lessor dealer terkait negosiasi dan pengaturan sewa (biaya langsung awal tidak termasuk). Oleh karena itu, biaya tersebut tidak termasuk investasi sewa neto dan diakui sebagai beban ketika laba penjualan diakui, dimana untuk sewa pembiayaan umumnya diakui pada masa awal sewa.

Transaksi ljarah dan IMBT adalah instrumen keuangan bank syariah, yang berbeda dalam memperlakukan pengungkapan dan pengukuran aset yang disewakan, akuntansi bank syariah untuk biaya langsung awal dan perbaikan aset yang disewakan. 
Untuk pengakuan pendapatan ljarah sebagian bank syariah mengakui pendapatan ljarah adalah ketika cicilan sewa jatuh tempo, dan sebagian lain mengakui diberbagai waktu. Terdapat pula Perbedaan pada perlakuan akuntansi dan pengungkapan yang memiliki beberapa efek yaitu sulit dibandingkannya keuntungan yang diperoleh oleh satu bank syariah dengan bank syariah lainnya. Perbedaan ini dapat mempengaruhi alokasi hasil investasi baik keuntungan maupun kerugian antara pemilik rekening investasi tidak terbatas dan para pemilik equity di satu sisi.

Standarisasi perlakuan dan pengungkapan akuntansi, sesuai dengan ketentuan "Penentuan hak-hak dan kewajiban semua pihak terkait, termasuk hak yang berasal dari transaksi yang tidak selesai dan kejadian lainnya sesuai dengan prinsip Syari'ah Islam sesuai konsep keadilan, charity dan kepatuhan terhadap etika bisnis Islam, dan memberikan informasi yang berguna bagi para pemakai laporan keuangan bank syariah".

\section{E. Akun Transaksi Pembiayaan ljarah}

1. Akun Laporan Posisi Keuangan (Neraca)

Terdapat beberapa akun dalam pencatatan transaksi ljarah dengan tujuan untuk pembuatan Laporan Posisi Keuangan (neraca) yaitu:

\section{c. Aset ljarah}

Pencatatan atas objek ljarah berupa aset berwujud dan tidak berwujud. Di posisi debet ketika dilakukan transaksi ljarah 
sebesar jumlah harga perolehan. Disisi kredit saat dilakukan penyusutan atas aset berwujud, dan amortisasi atas aset tidak berwujud.

\section{d. Akumulasi Penyusutan Aset ljarah}

Untuk mencatat penyusutan Objek ljarah berupa aset berwujud. Berada dikredit ketika dibentuk penyusutan objek ljarah sejumlah beban penyusutan yang dilakukan. Sedangkan, didebet saat aset dipindah kepemilikanke pihak lain, dan sebagai pengurang dari Aset ljarah.

\section{e. Sewa Multijasa Tangguhan.}

Mencatat biaya perolehan objek ijarah berupa aset tidak berwujud. Disisi debet saat dilakukan pembayaran biaya perolehan ijarah berupa aset tidak berwujud senilai biaya perolehan yang dikeluarkan. Ada dikredit ketika dilakukan amortisasi obyek ijarah sebesar beban amortisasi yang dilakukan.

\section{f. Cadangan biaya pemeliharaan.}

Untuk pembentukan cadangan biaya pemeliharaan obyek ijarah. Akun ini disisi kredit saat pembentukan cadangan sebesar cadangan yang dibentuk. Dan didebet ketika nili biaya pemeliharaan sejumlah pengeluaran beban pemeliharaan yang dibayar. 
2. Beberapa akun pada Laporan Laba Rugi

Akun yang ada dalam pencatatan transaksi ljarah untuk pembuatan Laporan Posisi Keuangan, yaitu:

\section{a. Biaya Penyusutan Aset ljarah}

Pencatatan atas biaya penyusutan atas obyek ijarah berupa aset berwujud, baik ijarah maupun IMBT. Akun ini disajkan bukan sebagai beban operasional tetapi sebagai pengurang dari Akun Pendapatan ljarah. Berada didebet ketika penyusutan obyek ijarah aset berwujud sebesar beban penyusutan yang dibentuk sesuai metode penyusutan berlaku. Dan dikredit saat akhir tahun..

\section{b. Biaya Pemeliharaan Aset ljarah}

Pencatatan atas biaya pemeliharaan obyek ijarah yang menjadi tanggung jawab pemilik obyek ijarah atas aset berwujud. Akun ini disajkan sebagai pengurang dari Akun Pendapatan ljarah. Berada didebet ketika dilakukan pemeliharaan obyek ijarah sebesar beban yang dikeluarkan. Dan dikredit saat akhir tahun bersama dengan pendapatan ijarah yang dipindahkan ke Pendapatan Operasi Utama.

\section{c. Biaya Amortisasi Aset ljarah}

Untuk mencatat beban amortisasi yang telah dilakukan atas obyek ijarah aset tidak berwujud. Akun ini disajkan sebagai 
pengurang (offsetting account) dari Akun Pendapatan ljarah. Akun ini didebet saat dilakukan pembentukan amortisasi sebesar beban amortisasi sesuai metode penyusutan yang kenakan dan disisi kredit ketika akhir tahun dimana pendapatan ijarah dipindahkan ke Pendapatan Operasi Utama.

\section{d. Keuntungan Pelepasan Aset ljarah}

Digunakan untuk mencatat keuntungan Aset ljarah, baik Asaet ljarah maupun IMBT atas aset berwujud dimana nilai tercatat lebih kecil dari nilai jualnya. Akun ini disajikan sebagai penambahan pendapatan ljarah (tidak disajikan sebagai pendapatan operasional). Disisi kredit terjadi pelepasan Aset ljarah sebesar selisih nilai tercatat dengan nilai jual aset ijarah. Sedangkan didebet bersama dengan pendapatan ljarah sebagai pendapatan operasi utama.

\section{g. Kerugian Pelepasan Aset ljarah}

Mencatat ketika ada kerugian Aset ljarah, baik aset ljarah maupun IMBT atas aset berwujud dimana nilai tercatat lebih besar dari nilai jualnya. Disajikan dengan bentuk pengurang pendapatan ljarah (bukan sebagai beban operasional). Didebet saat pelepasan Aset ljarah sebesar selisih antara nilai tercatat dengan nilai jual. sedangkan 
dikredit bersama dengan pendapatan ljarah sebagai pendapatan utama.

\section{h. Pendapatan Sewa}

Pencatatan atas harga sewa yang harus dibayar oleh penyewa. Disebalah kredit ketika diterimanya harga sewa sebesar harga yang disepakati, sedangkan disisi debet saat akhir tahun dan diakui sebagai Pendapatan Usaha Utama.

\section{F. Rangkuman}

"Ijarah" berasal dari bahasa Arab yang disebut "lijaar" yang memiliki arti "memberi upah" atau "menyewa". Akad ijarah adalah akad yang memfasilitasi transaksi pemindahan hak guna (maanfaat) atas suatu barang atau jasa dalam waktu yang ditentukan dengan pembayaran berupa upah sewa tanpa diikuti pemindahan kepemilikan. Dasar hukum terkait diperbolehkannya al-ijarah dalam alQuran, sebagai berikut:

1. Surah at-Thalaq ayat 6 yang berbunyi "Jika mereka telah menyusukan anakmu, maka berilah upah mereka"

2. Surah Al-Qashash ayat 26, berbunyi "Salah seorang dari wanita itu berkata: wahai bapakku, upahlah dia, sesungguhnya orang yang engkau upah itu adalah orang yang kuat dan dapat dipercaya".

Rukun dalam transaksi ijarah itu yaitu : 
1. Orang yang beraqad, yakni pihak penyewa ( $\left.M u^{\prime} j i r\right)$ dan orang yang menyewakan barangnya (Musta'jir).

2. Sewa atau Imbalan

3. Manfaat

4. Shighat (ljab Qabul)

Alur transaksi akad ijarah sebagai berikut :

1. Nasabah mengajukan pembiayaan ijarah ke bank syariah.

2. Bank syariah membeli/menyewa barang yang diinginkan oleh nasabah sebagai objek ijarah, dari supplier/penjual/pemilik.

3. Setelah dicapai kesepakatan antara nasabah dan bank mengenai barang objek ijarah, tarif ijarah, periode ijarah dan biaya pemeliharaannya, maka akad pembiayaan ijarah ditanda tangani. Nasabah diwajibkan menyerahkan jaminan yang dimiliki.

4. Bank menyerahkan objek ijarah kepada nasabah sesuai akad yang disepakati. Setelah periode ijarah berakhir, nasabah mengembalikan objek ijarah tersebut kepada bank.

5. Bila bank memebeli objek ijarah tersebut (al-bai' wal ijarah) maka setelah periode ijarah berakhir objek ijarah tersebut disimpan oleh bank sebagai asset yang dapat disewakan kembali.

6. Bila bank menyewa objek ijarah tersebut (al ijarah wal ijarah, atau ijarah pararel), maka setelah 
periode tersebut dikembalikan oleh bank kepada supplier/ penjual/ pemilik.

\section{G. Studi Kasus Transaksi Pembiayaan ljarah}

Tanggal 02 September 2016, disepakati transaksi ijarah antara Bank Berkah Sejahtera dan tuan Zaki atas manfaat aset berupa ruko. Atas kesepakatan tersebut, Bank membeli sebuah ruko yang diinginkan oleh nasabah dengan biaya perolehan sebesar Rp 250.000.000.

- Jurnal saat pengakuan aset ijarah:

\begin{tabular}{|l|l|l|l|}
\hline \hline 02 & & & \\
Sept & Dr & Aset ljarah & Rp 250.000.000 \\
2016 & & & \\
\hline \hline & Cr & Kas & Rp250.000.000 \\
\hline
\end{tabular}

Aset ijarah berupa ruko yang disewa oleh tuan Zaki, diasumsikan memiliki umur ekonomis 10 tahun dan disusutkan dengan metode garis lurus. Nilai penyusutan per tahun Rp 25.000 .000 (10\% x 250 juta) atau Rp 2.083.333 per bulan.

Jurnal transaksi penyusutan perbulan: 


\begin{tabular}{||l|l||l|l||}
\hline \hline $\begin{array}{l}\text { Sept } \\
2016\end{array}$ & Dr & $\begin{array}{l}\text { Beban Penyusutan Aset } \\
\text { ljarah }\end{array}$ & Rp 2.083.333 \\
\hline \hline & Cr & $\begin{array}{l}\text { Akumulasi Penyusutan Aset } \\
\text { ljarah }\end{array}$ & Rp2.083.333 \\
\hline
\end{tabular}

Disepakati antara bank dan tuan Zaki harga sewa ruko Rp 30.000.000 per tahun untuk jangka waktu 5 tahun. Pembayaran dilakukan secara angsuran per bulan setiap tanggal 02 sebesar Rp 2.500.000.

Jurnal transaksi saat pembayaran :

\begin{tabular}{|l|l|l|l||}
\hline \hline 02 & & & \\
Okt & Dr & Kas & Rp 2.500.000 \\
2016 & & & \\
\hline \hline & $\mathrm{Cr}$ & Pendapatan Ujroh & Rp2.500.000 \\
\hline
\end{tabular}


Jurnal jika pada saat tanggal tagih, nasabah tidak melakukan pembayaran:

\begin{tabular}{|l|l||l|l|}
\hline \hline 02 & & & \\
Okt & Dr & Piutang ljarah & Rp 2.500.000 \\
2016 & & & \\
\hline \hline & Cr & Pendapatan Ujroh & Rp2.500.000 \\
\hline
\end{tabular}

Jurnal pada saat nasabah melakukan pembayaran:

\begin{tabular}{|l||l||l||l||}
\hline 05 & & & \\
Okt & Dr & Kas & Rp 2.500.000 \\
2016 & & & \\
\hline \hline & $\mathrm{Cr}$ & Piutang ljaroh & Rp2.500.000 \\
\hline
\end{tabular}

Tanggal 20 Oktober 2016 terjadi kerusakan atap ruko dan dilakukan perbaikan seharga Rp 500.000 yang langsung diperbaiki oleh pihak bank.

\begin{tabular}{|l|l|l|l|}
\hline 20/10/2016 & Dr & Beban Perbaikan Aset & Rp 500.000 \\
\hline & Cr & Kas & Rp500.000 \\
\hline
\end{tabular}


Penyajian ljarah pada Laporan Keuangan Bank Syariah Laporan Posisi Keuangan

Periode 2xx

\begin{tabular}{|l||l||}
\hline ASET & LIABILITAS \\
Kas & \\
Penempatan pada BI & \\
Penempatan pada Bank & Piutang \\
- Piutang Murabahah & DANA SYIRKAH TEMPORER \\
- Pembiayaan ljarah & EKUITAS \\
Aset ljarah \\
(-) Akum Penyusutan Aset \\
ljarah \\
Aset Tetap
\end{tabular}




\section{Laporan Laba Rugi}

Periode 2xx

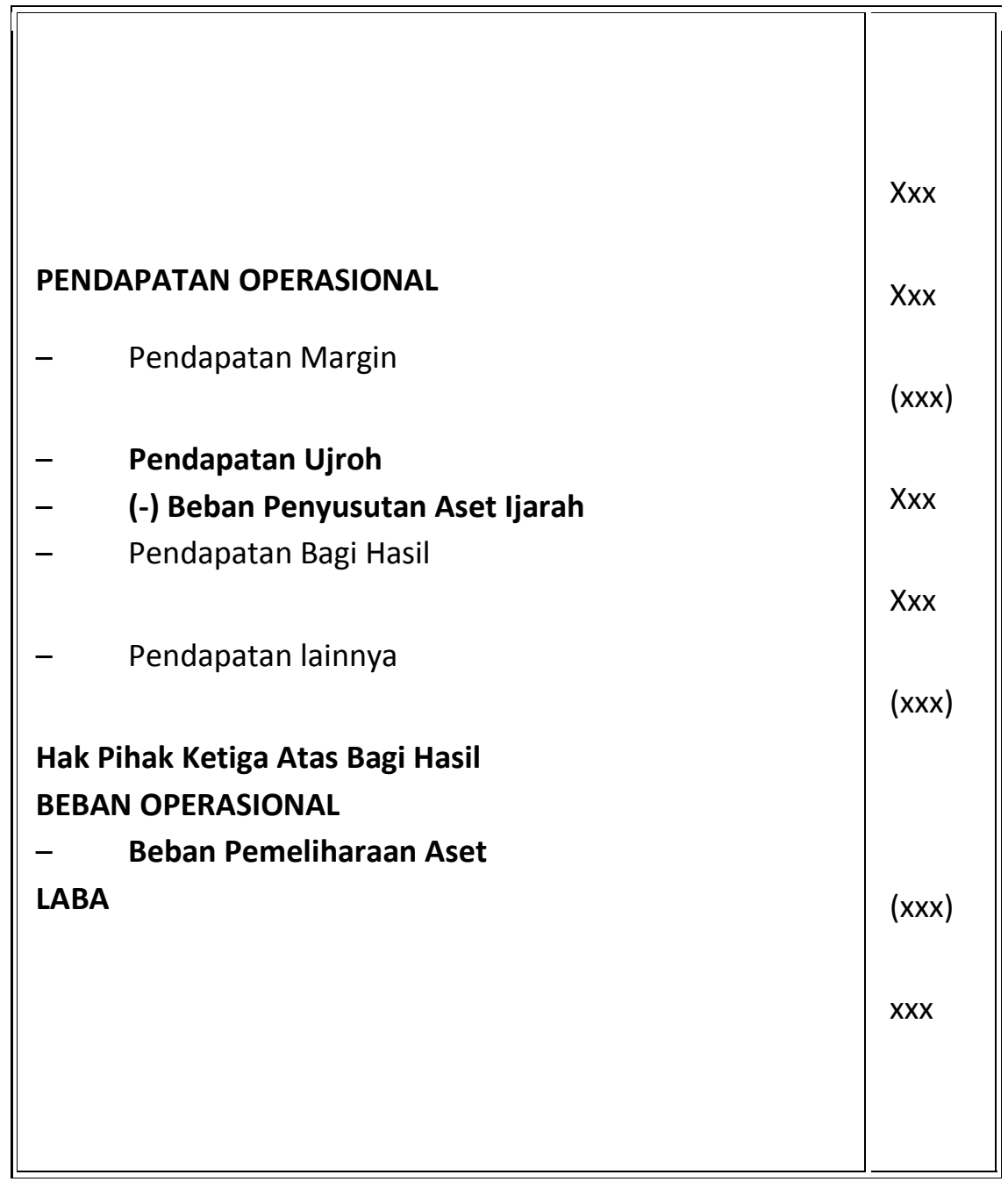




\section{Soal-Soal Latihan :}

\section{A. Soal Teori}

1. Jelaskan apa yang dimaksud dengan ijarah.

2. Jelaskan perbedaan antara antara ijarah dengan ijarah muntahiya bittamlik.

3. Jelaskan rukun transaksi ijarah.

4. Jelaskan bentuk pengawasan syariah pada transaksi ijarah dan IMBT.

5. Jelaskanlah keuntungan penggunaan transaksi ijarah dibanding jenis akad lainnya.

\section{B. Soal Kasus}

Bapak Hasanudin membutuhkan sebuah bangunan kantor untuk keperluan usahanya. Pada awal bulan Maret 20XB, Bapak Hasanudin mengajukan permohonan ijarah kepada Bank Syariah Nahdatul Ulama (BSNU). Permohonan tersebut disetujui dengan menggunakan pola sewa atas sewa kepada pemilik bangunan. Pernyataan atas penyewaan diatas adalah:

- tujuan pembiayaan: pembiayaan modal kerja untuk sebuah bangunan kantor

- jangka waktu: 18 bulan 
- ujroh bank (margin sewa): Rp 4.051.372,01 (margin annuitas $12 \%$, periode 18 bulan)

- total harga sewa: Rp 64.051.372,01

- $\quad$ uang muka nasabah: Rp 10.000.000,00

- jumlah pembiayaan: Rp 50.000.000,00

- sewa yang diangsur: Rp 54.051.372,01 (pembiayaan bank Rp 50 juta + keuntungan bank)

- angsuran pembiayaan: Rp 3,002,854.00 ( Rp 54.051.372,01: 18 bulan)

- amortisasi perbulan : Rp 2,777,777.78 (Rp $50.000 .000: 18$ bulan)

Buatlah jurnal untuk transaksi berikut:

1. Tanggal 7 Maret, Bapak Hasanudin dan BSNU menyepakati akad ljarah untuk sebuah bangunan kantor. Pada tanggal tersebut bank menyerahkan dana sebesar Rp 50.000.000 ke pemilik bangunan kantor untuk keperluan sewa Bapak Hasanudin

2. Tanggal 7 April 20XA, Saat jatuh tempo angsuran pertama, bank syariah melakukan amortisasi aset ijarah sebesar Rp 2,777,777.78. Pada saat itu Bapak Hasanudin membayar angsuran ijarah pertamanya sebesar Rp 3.002.854,00 
3. Tanggal 7 Mei 20XA, Saat jatuh tempo angsuran kedua, bank syariah melakukan amortisasi aset ijarah sebesar Rp 2,777,777.78. Pada saat itu Bapak Hasanudin belum dapat membayar angsuran keduanya.

4. Tanggal 10 Mei 20XA, Bapak hasanudin melakukan pembayaran angsuran keduanya.

5. Tanggal 7 Juni 20XA, saat tanggal jatuh tempo ketiga, bank syariah melakukan amortisasi aset ijarah. Pada saat itu, Bapak Hasanudin hanya membayar angsurannya sebesar Rp 1.000.000

6. Tanggal 14 Juni 20XA, Bapak Hasanudin membayar sisa angsuran tahap ketiga sebesar Rp 2.002.854,00

7. Tanggal 20 Juni 20XA, Bapak Hasanudin melunasi semua sisa sewa hingga bulan ke 18 sebesar Rp $45,042,810.01$. 


\section{BAB IX \\ TEORI DAN PRAKTEK AKUNTANSI TRANSAKSI WADIAH}

\section{Kompetensi Dasar}

Setelah mempelajari bab ini, diharapkan membentuk mahasiswa yang kompeten dalam hal berikut :

1. Mampu melakukan pencatatan transaksi akuntansi dengan akad Wadi'ah.

2. Pemahaman terhadap pengakuan dan pengukuran, penyajian serta pengungkapan akuntansi Wadi'ah.

\section{Indikator}

Indikator yang ada dalam bab ini, sebagai berikut :

1. Kemampuan proses akuntansi untuk transaksi akad Wadi'ah.

\section{Materi Pokok}

Materi utama pada bab ini adalah Akuntansi penghimpunan dana dengan akad Wadi'ah.

\section{A. Definisi Wadiah}

Dalam bahasa Arab, wadi"ah (وديعة) berarti titipan $^{73}$. Sedangkan dalam Kamus Istilah Fiqih, wadi"ah berarti menitipkan sesuatu kepada orang lain

\footnotetext{
${ }^{73}$ Dwi Suwiknyo, Kamus Lengkap Ekonomi..., (Jakarta: Total Media, 2009), hal. 269.
} 
berdasarkan amanah atau kepercayaan agar dijaga dan dipelihara dengan baik dan semestinya ${ }^{74}$.

Secara Etimologi al-Wadiah berarti titipan murni (amanah).Wadiah bermakna amanah. Wadiah dikatakan bermakna amanah karena Allah menyebut wadiah dengan kata amanah dibeberapa ayat AlQuran, sedangkan secara terminologi ada beberapa pendapat dari para ulama, di antaranya:

a. Hanafiah: al-wadi'ah adalah suatu amanah yang ditinggalkan untuk dipeliharakan kepada orang lain

b. Malikiah: al-wadi'ah adalah suatu harta yang diwakilkan kepada orang lain untuk dipeliharakan

c. Syafi'iah: al-wadi'ah adalah sesuatu harta benda yang disimpan ditempat orang lain untuk dipeliharakan

d. Hanabilah: suatu harta yang diserahkan kepada seseorang untuk memeliharanya tanpa adanya ganti rugi

e. Ulama Fiqh Kontemporer: al-Wadi'ah adalah titipan murni dari satu pihak ke pihak lain, baik individu maupun badan hukum yang harus dijaga dan dikembalikan kapan saja si penitip menghendakinya.

\footnotetext{
${ }^{74}$ Abdul Madjid, Fiqh Muamalah, (Bandung: Pustaka Setia, 2001), hal. 159.
} 
Pengertian Wadiah juga dapat diartikan sebagai titipan dari satu pihak ke pihak lain, baik individu maupun badan hukum yang harus dijaga dan dikembalikan kapan saja penyimpan menghendakinya ${ }^{75}$. Tujuan dari perjanjian tersebut adalah untuk menjaga keselamatan barang itu dari kehilangan, kemusnahan, kecurian dan sebagainya. Yang dimaksud dengan barang disini adalah suatu yang berharga seperti uang, barang, dokumen, surat berharga dan barang lain yang berharga disisi Islam.

Jadi wadiah adalah merupakan titipan murni yang bersifat tolong menolong antar sesama manusia, Jadi wadiah adalah merupakan titipan murni yang bersifat tolong menolong antar sesama manusia ${ }^{76}$, dari satu pihak ke pihak lain, baik individu maupun badan hukum yang harus dijaga dan dikembalikan kapan saja si penitip menghendaki.

\section{B. Rukun Wadiah}

Setiap perjanjian yang dilakukan oleh umat Islam harus memenuhi syarat dan rukunnya. Jika salah satu rukun suatu perjanjian tidak terpenuhi, maka perjanjian tersebut batal atau tidak sah. Seperti halnya iman seseorang yang harus dilandasi oleh 6 (enam) Rukun Iman; Iman kepada Allah, MalaikatNya,

\footnotetext{
${ }^{75}$ Wiroso. 2009. Produk Perbankan Syariah. Edisi 1. Cetakan

Pertama. Jakarta. LPFE Universitas Trisakti

${ }^{76}$ S.RSjahdeini, Perbankan Islam dan Kedudukannya Dalam Tata Hukun Perbankan Indonesia, (cet. I, Jakarta, Pustaka Utama Grafitti, 1999), 55
} 
RasulNya, Kitab-kitabNya, Hari Kiamat dan TakdirNya, seandainya seseorang mengaku dirinya telah beriman kepada Allah dan telah melakukan amal ibadah yang diperintahkanNya, tapi ia tidak yakin akan kebenaran Nabi Muhammad Saw sebagai Rasul yang terakhir, maka sia-sia pengakuan iman dan ibadah orang terserbut. Karena ia meninggalkan salah satu rukun iman yang ke tiga (iman kepada Rasul-Rasul Allah).

Menurut Hanafiah: Rukun wadi'ah menurutnya hanya satu, yaitu adanya pernyataan kehendak (sighat: ijab (ungkapan kehendak menitipkan barang dari pemiliknya) dan qabul (ungkapan kesiapan menerima titipan tersebut oleh pihak yang dititipi). Namun menurut Jumhur ulama Fiqh: Rukun wadi'ah ada empat ${ }^{77}$ :

1. Barang yang dititipkan (wadiah)

2. Orang yang menitipkan (mudi' atau muwaddi')

3. Orang yang menerima titipan (muda' atau mustawda')

4. ljab qabul (sighat)

Syarat-syarat wadi'ah berkaitan dengan rukun-rukun yang telah disebutkan di atas, yaitu syarat benda yang dititipkan, syarat sighat, syarat orang yang menitipkandan syarat orang yang dititipi.

\footnotetext{
${ }^{77}$ Ahmad Wardi Muslich, Fiqih Muamalah, Jakarta:Amzah,2010,h. 459
} 
a. Syarat-Syarat Untuk Benda Yang Dititipkan Syaratsyarat benda yang dititipkan sebagai berikut :

1) Benda yang dititipkan disyaratkan harus benda yang bisa untuk disimpan. Apabila benda tersebut tidak bisa disimpan, seperti burung di udara atau benda yang jatuh ke dalam air, maka wadi'ah tidak sah sehingga apabila hilang, tidak wajib mengganti. Syarat ini dikemukakan oleh ulama-ulama Hanafiyah.

2) Syafi'iyah dan Hanabilah mensyaratkan benda yang dititipkan harus benda yang mempunyai nilai (qimah) dan dipandang sebagai mal, walaupun najis. Seperti anjing yang bisa dimanfaatkan untuk berburu, atau menjaga keamanan. Apabila benda tersebut tidak memiliki nilai, seperti anjing yang tidak ada manfaatnya, maka wadi'ah tidak sah.

b. Syarat- Syarat Sighat Sighat akad adalah ijab dan qabul. Syarat sighat adalah ijab harus dinyatakan dengan ucapan atau perbuatan. Ucapan adakalanya tegas (sharih) dan adakalanya dengan sindiran (kinayah). Malikiyah menyatakan bahwa lafal dengan kinayah harus disertai dengan niat. Contoh 
lafal yang sharih: "Saya titipkan barang ini kepada Anda". Sedangkan contoh lafal sindiran (kinayah). Seseorang mengatakan, "Berikan kepadaku mobil ini". Pemilik mobil menjawab: "Saya berikan mobil ini kepada Anda". Kata "berikan" mengandung arti hibah dan wadi'ah (titipan). Dalam konteks ini arti yang paling dekat adalah "titipan". Contoh ijab dengan perbuatan: Seseorang menaruh sepeda motor di hadapan seseorang tanpa mengucapkan kata-kata apa pun. Perbuatan tersebut menunjukan penitipan (wadi'ah). Demikian pula qabul kadangkadang dengan lafal yang tegas (sharih), seperti: "Saya terima" dan adakalanya dengan dilalah (penunjukan), misalnya sikap diam ketika barang ditaruh di hadapannya.

c. Syarat orang yang menitipkan (Al-Mudi')

1) Berakal, Dengan demikian, tidak sah wadi'ah dari orang gila dan anak yang belum berakal.

2) Baligh, Syarat ini dikemukakan oleh Syafi'iyah. Dengan demikian menurut Syafi'iyah, wadi'ah tidak sah apabila dilakukan oleh anak yang belum baligh masih di bawah umur). Tetapi menurut Hanafiah baligh tidak menjadi syarat wadi'ah sehingga wadi'ah hukumnya sah apabila 
dilakukan oleh anak mumayyiz dengan persetujuan dari walinya atau washiy-nya

d. Syarat orang yang dititipi (Al-Muda') Syarat orang yang dititipi (muda') adalah sebagai berikut :

1) Berakal, tidak sah wadi'ah dari orang gila dan anak yang masih di bawah umur. Hal ini dikarenakan akibat hukum dari akad ini adalah kewajiban menjaga harta, sedangkan orang yang tidak berakal tidak mampu untuk menjaga barang yang dititipkan kepadanya.

2) Baligh, syarat ini dikemukakan oleh jumhur ulama. Akan tetapi, Hanafiah tidak menjadikan baligh sebagai syarat untuk orang yang dititipi, melainkan cukup ia sudah mumayyiz.

3) Malikiyyah mensyaratkan orang yang dititipi harus orang yang diduga kuat mampu menjaga barang yang dititipkan kepadanya.

\section{Skema Wadiah}

Dalam Islam wadi'ah dapat dibedakan menjadi dua macam, yaitu ${ }^{78}$ :

\footnotetext{
${ }^{78}$ Trisandini P. Usanti dan Abd. Shomad, Transaksi Bank Syariah, Jakarta: PT. Bumi Aksara, 2013, h. 37
} 
1. Wadi'ah yad Amanah yaitu barang yang dititipkan sama sekali tidak boleh digunakan oleh pihak yang menerima titipan, sehingga dengan demikian pihak yang menerima titipan tidak bertanggung jawab terhadap risiko yang menimpa barang yang dititipkan. Penerima titipan hanya punya kewajiban mengembalikan barang yang dititipkan pada saat diminta oleh pihak yang menitipkan secara apa adanya.

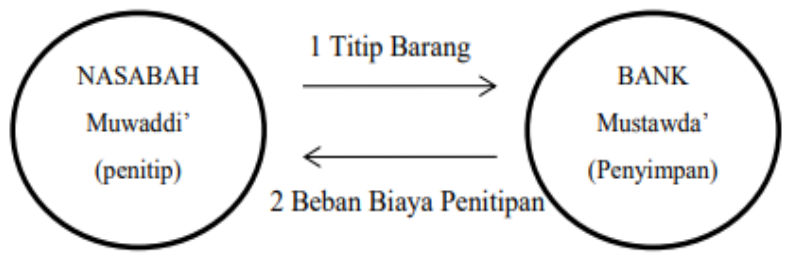

Keterangan : pada konsep wadi'ah yad Amanah, pihak yang menerima titipan tidak berhak menggunakan atau memanfaatkan uang maupun barang yang dititipkan. la harus benar-benar menjaganya sesuai kelaziman.

2. Wadi'ah yad Dhamanah adalah titipan terhadap barang yang dapat dipergunakan atau dimanfaatkan oleh penerima titipan. Sehingga pihak penerima titipan bertaggung jawab terhadap risiko yang menimpa barang sebagai akibat dari penggunaan atas suatu barang, seperti risiko kerusakan dan 
sebagainya. Tentu saja penerima titipan wajib menegmbalikan barang yang dititipkan pada saat diminta oleh pihak yang menitipkan ${ }^{79}$.

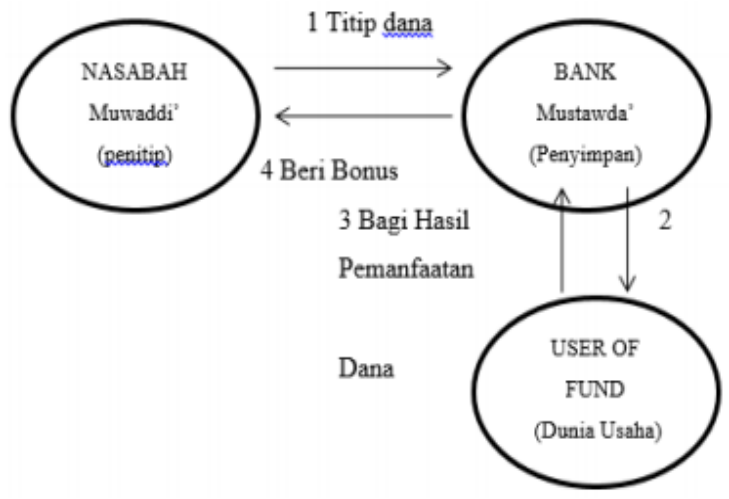

Keterangan : pada konsep wadi' ah yad Dhamanah, pihak yang menerima titipan boleh memanfaatkan atau menggunakan barang maupun uang yang dititipkan. Tentunya pihak bank dalam hal ini mendapatkan bagi hasil dari pengguna dana. Bank dapat memberikan insentif kepada penitip dalam bentuk bonus.

\section{Cakupan Akuntansi Wadiah \\ Pengakuan dan pengukuran dana Wadiah berdasarkan PSAK 59.}

${ }^{79}$ Trisadini P. Usanti dan Abd. Shomad, Transaksi Bank Syariah, Jakarta: PT. Bumi Aksara, 2013, h. 37 
1. Dana wadiah diakui sebesar jumlah dana yang dititipkan pada saat terjadinya transaksi dalam periode yang bersangkutan

2. Penerimaan yangdiperoleh atas pengelolaan dana titipan diakui sebagai pendapatan bank dan bukan merupakan unsur keuntungan yang dibagikan

a) Bonus transaksi wadiah menurut PSAK 59

1. Pembayaran bonus kepada nasabah diakui sebagai beban saat terjadinya penerimaan bonus :

- Berasal dari bank syariah lain dan bank sentral, hal tersebut diakui sebagai pendapatan pada saat kas diterima

- Berasal dari bank non-syariah, diakui sebagai qardhul hasan

b) Penyajian dan pengungkapan berdasarkan PSAK 59

1. Dana wadiah yad-dhamanah disajikan sebagai kewajiban

2. Pengungkapan transaksi wadiah, mencakup dan tidak terbatas pada :

- Jumlah dana atau barang yang mengikuti prinsip wadiah yad-dhamanah

- Jumlah dana wadiah yang diblokir sebagai jaminan pembiayaan dan transaksi perbankan lainnya 


\section{E. Rangkuman}

Wadiah merupakan titipan murni yang bersifat tolong menolong antar sesama, dari satu pihak ke pihak lain, baik individu maupun badan hukum yang harus dijaga dan dikembalikan kapan saja si penitip menghendaki.

Rukun Akad Wadi'ah sebagai berikut :

1. Barang yang dititipkan (wadiah)

2. Orang yang menitipkan (mudi' atau muwaddi')

3. Orang yang menerima titipan (muda' atau mustawda')

4. ljab qabul (sighat)

Wadi'ah dibedakan menjadi dua macam, yaitu:

1. Wadi'ah yad Amanah yaitu barang yang dititipkan sama sekali tidak boleh digunakan oleh pihak yang menerima titipan, sehingga pihak yang menerima titipan tidak bertanggung jawab terhadap risiko yang menimpa barang yang dititipkan. Penerima titipan hanya punya kewajiban mengembalikan barang yang dititipkan pada saat diminta oleh pihak yang menitipkan secara apa adanya.

2. Wadi'ah yad Dhamanah merupakan titipan dimana barang tersebut dapat dipergunakan atau dimanfaatkan oleh penerima titipan. Sehingga pihak penerima titipan bertaggung jawab terhadap risiko yang menimpa barang sebagai akibat dari penggunaan atas suatu barang, seperti risiko kerusakan dan sebagainya. Tentu saja 
penerima titipan wajib mengembalikan barang yang dititipkan pada saat diminta oleh pihak yang menitipkan.

\section{F. Studi Kasus Transaksi Wadiah}

- Pada tanggal 5 Maret 2018, Amira nasabah tabungan wadi'ah Bank Berkah menerima bonus wadi'ah sebesar Rp. 50.000 dan di potong pajak Rp. 10.000 .

\begin{tabular}{|l|l|l|l|}
\hline Tanggal & Akun & $\begin{array}{l}\text { Debit } \\
(\mathrm{Rp})\end{array}$ & $\begin{array}{l}\text { Kredit } \\
(\mathrm{Rp})\end{array}$ \\
\hline $\begin{array}{l}5018 \\
\text { Maret }\end{array}$ & $\begin{array}{l}\text { Beban bonus } \\
\text { Tab. Wadi'ah }\end{array}$ & 50.000 & \\
\hline & $\begin{array}{l}\text { Tabungan } \\
\text { Wadi'ah }\end{array}$ & & 50.000 \\
& $\begin{array}{l}\text { Tabungan } \\
\text { Wadi'ah }\end{array}$ & 10.000 & \\
\hline & $\begin{array}{l}\text { Pajak Tab. } \\
\text { Wadi'ah }\end{array}$ & 10.000 \\
\hline
\end{tabular}

- Tanggal 1 Juli 2018 bank Berkah mendapat setoran tunai atas pembukaan giro wadiah atas nama Amira sebesar Rp. 50.000.000

- Tanggal 5 Juli 2018 Amira menerima transfer dari bank Berkah cab. Jakarta sebesar Rp. 5.000 .000 
- Tanggal 10 Juli 2018 Amira memakai bilyet giro untuk membayar pembelian mesin kepada nasabah giro lain sebesar $\mathrm{Rp}$. 7.000.000.

- Tanggal 31 Juli 2018 Bank Berkah memberikan bonus kepada Amira sebesar Rp. 100.000 dan dikenakan biaya administrasi giro yaitu Rp. 15.000 serta pajak Rp. 10.000

\begin{tabular}{|l|l|l|l|}
\hline Tanggal & Akun & Debit (Rp) & Kredit (Rp) \\
\hline 1 Juli 2018 & Kas & 50.000 .000 & \\
\hline Amira Wadiah & & 50.000 .000 \\
\hline 5 Juli 2018 & $\begin{array}{l}\text { RAK Cab. } \\
\text { Jakarta }\end{array}$ & 5.000 .000 & \\
\hline $\begin{array}{l}\text { Giro Wadiah } \\
\text { Amira Juli }\end{array}$ & $\begin{array}{l}\text { Giro Wadiah } \\
\text { Amira }\end{array}$ & 7.000 .000 & \\
\hline 318 & Juli pada BI & & \\
\hline 2018 & Beban Bonus & 100.000 & 7.000 .000 \\
\hline
\end{tabular}




\begin{tabular}{|ll|l|l|l|}
\hline & \multicolumn{2}{|c|}{$\begin{array}{l}\text { Giro Wadiah } \\
\text { Amira }\end{array}$} & 100.000 \\
\hline 31 & Juli & $\begin{array}{l}\text { Giro Wadiah } \\
\text { Amira }\end{array}$ & 15.000 & \\
\hline 318 & Juli & $\begin{array}{l}\text { Giro Wadiah } \\
\text { Adm. Giro W } \\
2018\end{array}$ & 10.000 & 15.000 \\
\hline & Amira & & \\
\hline & Pajak Negara & & 10.000 \\
\hline
\end{tabular}

- TangTanggal 07 Agustus 2008 Qohar mengajukan ke bank untuk pemindahbukuan dari rekening 
gironya sebesar Rp.5.000.000,--untuk dibuatkan Deposito Mudharabah dengan ketentuan nisbah 65:35

- Di tanggal yang sama, Yusuf melakukan setor tunai sebesar Rp.1.000.000,-- untuk setoran pertama giro wadiah

Atas transaksi diatas, bank syariah melakukan penjurnalan:

Dr. Giro Wadiah (Rek giro Qohar) $\quad 5.000 .000$

Cr. Deposito Mudharabah (a/n Qohar) $\quad 5.000 .000$

Dr. Kas

1.000 .000

Cr. Giro Wadiah (Rek giro Yusuf)

1.000 .000

Dari transaksi diatas terjadinya perubahan pada Buku Besar dan Posisi Neraca yaitu:

Buku Besar

Giro Wadiah

Debet

kredit

\begin{tabular}{|l|l|l|l|l|l|}
\hline Tgl & Keterangan & Jumlah & $T g l$ & Keterangan & Jumlah \\
\hline 05/ & Rekening Qohar & 2.000 .000 & $01 /$ & Rekening Qohar 20.000.000 \\
08 & & & 08 & & \\
$07 /$ & Rekening Qohar & 5.000 .000 & $07 /$ & Rekening Yusuf & 1.000 .000 \\
08 & & 08 & & \\
& \multirow{2}{*}{ Saldo } & 14.000 .000 & & & \\
& & 21.000 .000 & & & 21.000 .000 \\
\hline
\end{tabular}


NERACA

Per 07 Agustus 2008

Aktiva

Pasiva

\begin{tabular}{|l|l|l|l|}
\hline Uraian & Jumlah & Uraian & \multicolumn{1}{|l|}{ Jumlah } \\
\hline & & $\begin{array}{l}\text { Kewajiban } \\
\text { Giro Wadiah }\end{array}$ & 14.000 .000 \\
\hline
\end{tabular}

Terdapat perubahan Buku Besar Giro wadiah yang diakibatkan dari bertambahnya saldo rekening atas nama Qahar dan Yusuf, digambarkan sebagai berikut:

Rekening Giro Qohar

\begin{tabular}{|c|l|r|l|r|}
\hline Tgl & Keterangan & Debet & Kredit & Saldo \\
\hline 01/08 & Setoran awal & & 20.000 .000 & 20.000 .000 \\
05/08 & Penarikan ATM & 2.000 .000 & & 18.000 .000 \\
$07 / 08$ & Deposito & 5.000 .000 & & 13.000 .000 \\
\hline
\end{tabular}

Rekening Giro Yusuf

\begin{tabular}{|c|l|l|l|l|}
\hline Tgl & Ket & Debet & Kredit & Saldo \\
\hline $1 / 8$ & Setoran awal & & 1.000 .000 & 1.000 .000 \\
\hline
\end{tabular}

\section{Soal-soal Latihan :}

1. Buatlah jurnal untuk transaksi terkait dengan giro wadiah berikut:

\begin{tabular}{|l|l|}
\hline 5 Jan 20XA & $\begin{array}{l}\text { Bank Murni Syariah (BMS) cabang Bandung } \\
\text { menerima setoran tunai pembukaan giro }\end{array}$ \\
\hline
\end{tabular}




\begin{tabular}{|c|c|}
\hline & $\begin{array}{l}\text { wadiah atas nama Dina sebesar } \mathrm{Rp} \\
55.000 .000,-.\end{array}$ \\
\hline 6 Jan 20XA & $\begin{array}{l}\text { Dina menarik cek untuk mencairkan dananya } \\
\text { secara tunai sebesar Rp18.000.000 }\end{array}$ \\
\hline 7 Jan 20XA & $\begin{array}{l}\text { Dina mengeluarkan bilyet giro untuk } \\
\text { mentransfer sejumlah dana ke rekening Angga } \\
\text { nasabah tabungan BMS cabang Bogor sebesar } \\
\text { Rp7.000.000,- }\end{array}$ \\
\hline $\begin{array}{l}10 \text { Jan } \\
20 X A\end{array}$ & $\begin{array}{l}\text { Dina menerima transfer dari BMS cabang } \\
\text { Yogya sebesar Rp } 5.000 .000 \text { untuk rekening } \\
\text { giro Dina. }\end{array}$ \\
\hline $\begin{array}{l}15 \text { Jan } \\
20 X A\end{array}$ & $\begin{array}{l}\text { Dina mengeluarkan bilyet giro untuk } \\
\text { pembayaran pembelian sebuah mesin kepada } \\
\text { PT Andrizal Jaya nasabah giro Bank Berkah } \\
\text { Syariah (BBS) sebesar Rp } 15.000 .000 .\end{array}$ \\
\hline $\begin{array}{l}20 \text { Jan } \\
20 X A\end{array}$ & $\begin{array}{l}\text { Dina menerima transfer dari BMS cabang Solo } \\
\text { sebesar Rp 5.000.000. }\end{array}$ \\
\hline $\begin{array}{l}23 \text { Jan } \\
20 X A\end{array}$ & $\begin{array}{l}\text { Dina menerima bilyet giro dari Fajar nasabah } \\
\text { Bank Peduli Syariah (BPS) yang pernah } \\
\text { membeli sesuatu dari Dina seharga Rp } \\
\text { 15.000.000. Bilyet giro tersebut dicairkan oleh } \\
\text { Gina ke BPS untuk dimasukkan ke rekening } \\
\text { giro Gina di Bank Murni Syariah cabang } \\
\text { Jakarta. }\end{array}$ \\
\hline
\end{tabular}




\section{DAFTAR PUSTAKA}

Anshori, Abdul Ghofur. Perbankan Syariah Di Indonesia. Yogyakarta: Gadjah Mada University Press, 2018.

Ascarca. Akad Dan Produk Bank Syariah. Jakarta: Raja Grafindo, 2007.

Ayyub, Hasan. Fiqh Al-Mu'amaalat Al-Maliyyah Fi Al-Islam. Kairo: Dar al-Salam, 2003.

Daffa Muhammad Dzubyan, Erina Azzahra, Melani Puspitasari. "ANALISIS AKAD IJARAH MUNTAHIYA BITTAMLIK (IMBT) DALAM PERSPEKTIF HUKUM ISLAM DAN HUKUM POSITIF DI INDONESIA." Jurnal Ekonomi dan Keuangan Syariah 3, no. 2 (2019): 181-196.

Danupranata, G. Buku Ajar Manajemen Perbankan Syariah Gita Danupranata. Salemba Empat. Jakarta: Salemba Empat, 2013.

Insawan, Husain, Fakultas Ekonomi, and Islam lain. "A I I Jarah Dalam Perspektif Hadis; KajianHadisdengan Metode M Audhu'iy." Jurnal Studi Ekonomi dan Bisnis Islam 2, no. 1 (2017).

Khaddafi, Muammar. Akuntansi Syariah: Meletakkan NilaiNilai Syariah Islam Dalam IImu Akuntansi. Edited by Arfan Ikhsan. Cetakan 1. Medan: Madenatera, 2016.

Khaddafi, Muammar, Saparuddin Siregar, Muhamad Yamin 
Noch, S A Nurlaila, Si Hendra Harmain, Pd Sumartono, Ak Editor, and Arfan Ikhsan. Akuntansi Syariah Meletakkan Nilai-Nilai Syariah Islam Dalam IImu Akuntansi. Medan: Madenatera, 2016.

M. Baidlowi Mufti, BA, Drs. Mahmud Yunus, Drs. H. Masroni, M.Pdl, M. Yusub, S. Ag. MP.dl, Mustofa, S.Ag. FIQIH, 2016.

Marthan. No, 2001.

Mawarid, Husnul. "Analisis Penerapan Akuntansi Keuangan (SAK) Nomer 105 Tentang Pembiayaan Mudharabah Pada Laporan Keuangan Koperasi Jasa Keuangan Syariah Kalbar Madani Pontianak." Audit dan Akuntansi Fakultas Ekonomi Universitas Tanjungpura 3, no. 2 (2014): 27-42.

Mubarok, Jaih, Hasanudin. Fikih Mu'amaliyah Maliyyah Akad Jual Beli. Bandung: Simbiosa Rekatama Media, 2017.

Muhammad. Manajemen Perbankan Syariah. Yogyakarta: UPP AMP YKPN, 2005.

Munif, Nasrulloh Ali. "BITTAMLIK DALAM PERSPEKTIF HUKUM ISLAM DAN HUKUM POSITIF DI INDONESIA." Jurnal AnNisbah 03, no. Article 1319 (2017).

- - . "ISLAM DAN HUKUM POSITIF DI INDONESIA." Jurnal AHKAM 4, no. article 1319 (2016): 57-80.

Muthaher, Osmad. Akuntansi Perbankan Syariah. Yogyakarta: Graha IImu, 2012. 
Nawawi, Ismail. Perbankan Syariah. Surabaya: VIVPRESS, 2011.

Polindi, Miko. "IMPLEMENTASI IJARAH DAN IJARAH MUNTAHIA BIT-TAMLIK (IMBT) DALAM PERBANKAN SYARIAH DI INDONESIA." Jurnal Al-Intaj 2, no. 1 (2016).

PSAK, and 106. Pedoman Standar Akuntansi Perbankan Syariah. Jakarta: Ikatan Akuntansi Indonesia, 2007.

Rasjid, H. Sulaiman. FIQH ISLAM, 1998.

Sofyan s, Harahap; Wiroso. Akuntansi Perbankan Syariah. Jakarta: KPFE Usakti, 2006.

Sriono, SH, M.Kn. "TELAAH TERHADAP PERJANJIAN SEWA MENYEWA." Jurnal Ilmiah "Advokasi" 01, no. 01 (2013): 88-98.

Sudarsono, Heri. Bank Dan Lembaga Kuangan Syariah. Yogyakarta: EKONISIA, 2012.

Umam, Khaerul. Manajemen Perbankan Syariah. Bandung: CV Pustaka Setia, 2013.

Wiroso. Akuntansi Transaksi Syariah. Jakarta: Ikatan Akuntan Indonesia, 2011.

- - - Produk Perbankan Syariah. Jakarta: LPFE Usakti, 2011.

Yahya, Rizal. Akuntansi Perbankan Syariah. Jakarta: Salemba Empat, 2009. 
Yaningwati, Fransisca. "ANALISIS PENGARUH PEMBIAYAAN MUDHARABAH DAN MUSYARAKAH TERHADAP TINGKAT PROFITABILITAS ( RETURN ON EQUITY) ( Studi Pada Bank Umum Syariah Yang Terdaftar Di Bank Indonesia Periode 2009-2012 )." jurnal administrasi Bisnis (JAB) 12, no. 1 (2014): 1-9. 


\section{BIODATA PENULIS}

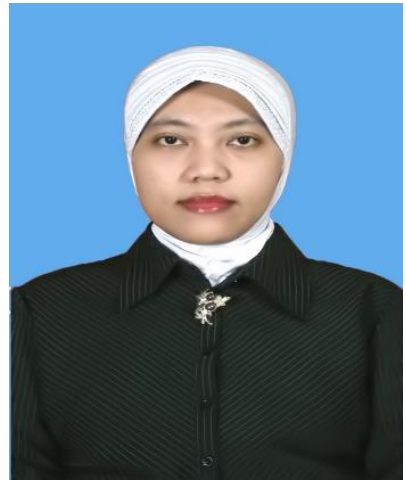

Dr. Renny Oktafia, S.E., M.E.I. lahir di Malang, 25 Oktober 1978. Lulus Sarjana Ekonomi Universitas Brawijaya Malang tahun 2003, melanjutkan studi S2 Ekonomi Islam Program Pascasarjana Institut Agama Islam Negeri Sunan Ampel Surabaya lulus tahun 2013. Lulus program Doktor di prodi Ilmu Ekonomi Islam Program Pascasarjana Universitas Airlangga Surabaya tahun 2019. Karir pengajaran dimulai tahun 2014 di Fakultas Agama Islam Universitas Muhammadiyah Sidoarjo. Penulis terlibat dalam penelitian dan pengabdian kepada masyarakat baik didanai oleh Ristekdikti, Internal maupun dana mandiri tentang kajian rumpun ekonomi syariah.

Nihlatul Qudus Sukma Nirwana, S.E., M.M. dilahirkan di Sidoarjo, 9 September 1975. Lulus Sarjana Ekonomi Jurusan Akuntansi Universitas Muhammadiyah Surabaya tahun 2001, melanjutkan studi S2 Manajemen Program Pascasarjana Universitas Muhammadiyah Sidoarjo lulus tahun 2013.

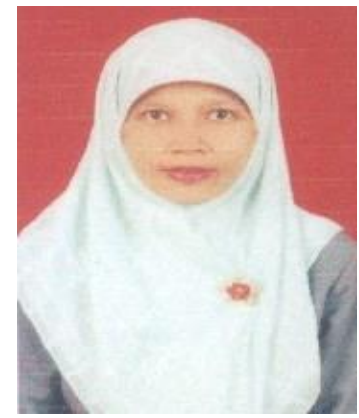

